\title{
THE LEgaCy OF
}
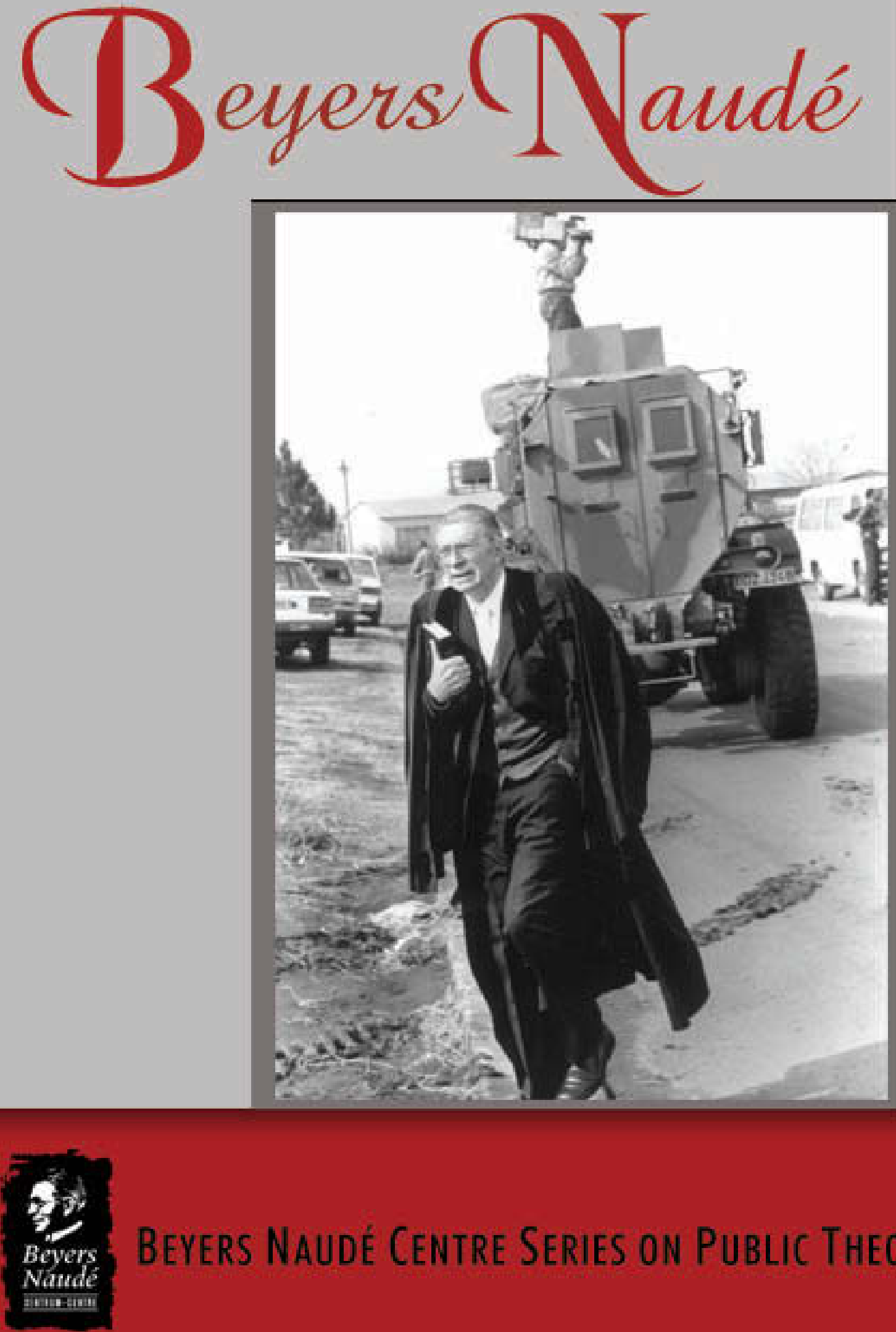

Beyers naudé Centre Series on Public Theology 
Beyers Naudé Centre Series on Public Theology Volume 1

THE LEGACY OF BEYERS NAUDé 
The Legacy of Beyers Naudé

Beyers Naudé Centre Series on Public Theology

Published by SUN PReSS, a division of AFRICAN SUN MeDIA, Stellenbosch 7600

www.africansunmedia.co.za

www.sun-e-shop.co.za

All rights reserved.

Copyright (C) 2005 Stellenbosch University, Beyers Naudé Centre

Image on cover design used with kind permission of Beeld

No part of this book may be reproduced or transmitted in any form or by any electronic, photographic or mechanical means, including photocopying and recording on record, tape or laser disk, on microfilm, via the Internet, by e-mail, or by any other information storage and retrieval system, without prior written permission by the publisher.

First edition 2005

ISBN: 978-1-919980-98-0

e-ISBN: 978-1-919980-99-7

DOI: $10.18820 / 9781919980997$

Cover design by Soretha Botha

Typesetting by SUN MeDIA Stellenbosch

Set in 10/12 Palatino Linotype

SUN PReSS is a division of AFRICAN SUN MeDIA, Stellenbosch University's publishing division.

SUN PReSS publishes academic, professional and reference works in print and electronic format. This publication may be ordered directly from www.sun-e-shop.co.za 


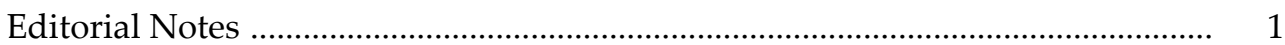

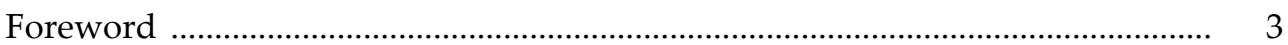

The Life and Legacy of Beyers Naudé

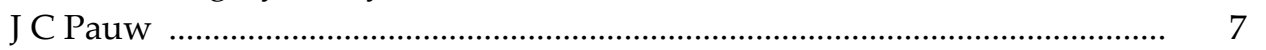

FROM THE ARCHIVES: Obedience to God

Beyers Naudé ……………………………………………………………... 25

Beyers Naudé and The Christian Institute

Dr M Nash

FROM THE ARCHIVES: The Flame of Fire and Sledgehammer

Beyers Naudé

Beyers Naudé: Unlikely Champion of Justice

Archbishop D M Tutu .

FROM THE ARCHIVES: The Afrikaner and Race Relations

Beyers Naudé

Beyers Naudé: Public Theologian

Prof. D M Ackermann

FROM THE ARCHIVES: Steve Biko: The Man and His Message

Beyers Naudé

Beyers Naudé and Public Theology

Prof. J W De Gruchy

FROM THE ARCHIVES: The Need for Political Reform

Beyers Naudé

The Political Worship of God - The Example of Beyers Naudé

Prof. M Rumscheidt

FROM THE ARCHIVES: Christian Involvement in the Struggle for Human Rights and Justice

Beyers Naudé 
Dr Beyers Naudé and Church Unification

in the Family of Dutch Reformed Churches

Prof. J C Adonis

FROM THE ARCHIVES: Confessing the Faith in South Africa Today

Beyers Naudé

Beyers Naudé: Respice Prospice

Dr A A Boesak

FROM THE ARCHIVES: Reconciliation

Beyers Naudé

Beyers Naudé's Relevance for the DRC Today

Dr C A Anthonissen

FROM THE ARCHIVES: The People

Beyers Naudé

“This is how he is!" Beyers Naudé - Man of Character and Virtue

Prof. N N Koopman 
The contents of this publication are of a twofold nature: (1) published works of Beyers Naudé, from the archives of the Beyers Naudé Centre for Public Theology at the University of Stellenbosch, and (2) those works of other authors that deal with aspects of the legacy of Beyers Naudé. The latter group of contributions can be further divided into three categories: (1) Some, like those of Nico Koopman and Christoff Pauw, have been written especially for this publication. (2) The majority, however, were originally intended as addresses delivered at the Beyers Naudé Centre. These include the address by Archbishop Emeritus Desmond Tutu at the official opening of the Centre on 21 November 2002, while those by Hannes Adonis, Carel Anthonissen, Allan Boesak, John de Gruchy and Margaret Nash were all delivered as part of the $89^{\text {th }}$ birthday celebrations of Beyers Naudé on 31 May 2004. (3) A third category of contributions, those by Denise Ackermann and Martin Rumscheidt, were given as guest lectures at the Centre in Stellenbosch. Because these addresses were originally delivered on occasions that varied in nature and formality, the addresses themselves differ too, for example, regarding the presence or absence of formal references or the degree of academic or personal reflection. Furthermore, because all contributions deal with one man, his life and legacy, a certain degree of repetition regarding the historical facts was inevitable, yet inextricably linked to the authors' reflection on and interpretation of (often) the same historical facts, but from different perspectives.

Some of the most important articles or published addresses by Beyers Naudé himself will be found interspersed among those of the above authors under the heading "From the Archives". Because of space restrictions a difficult selection had to be made from the material available for this purpose. This selection was finally made (1) because of their importance as markers of the most significant events in Beyers Naudé's life (for example, Obedience to God, the sermon he delivered in 1963 to his congregation - Aasvoëlkop, Johannesburg - when he made clear his decision to join the Christian Institute, and The Flame of Fire and Sledgehammer, his farewell sermon to that congregation two months later), or (2) because they shed light on the reflections of one or more of the other authors in the publication (for example, Beyers Naudé's own reflections on the history and current state of Afrikanerdom and the race issue - The Afrikaner and Race Relations - was chosen as it relates to Margaret Nash's interpretation of aspects of Afrikaner history and its influence on the formation and career of Beyers Naudé as well as to Archbishop Desmond Tutu's reflections on Beyers Naudé's Afrikaner roots; Hannes Adonis's comments on Beyers Naudé's influence on the unification process within the Dutch Reformed family of churches and especially on the formation of the URCSA relates, in turn, to the address of Beyers Naudé - Confessing the Faith in South Africa Today - before the Belydendekring, a society within the old Dutch Reformed Mission Church). 
On behalf of Nico Koopman and Dirkie Smit, respectively the director and chairperson of the board of the Beyers Naudé Centre, as well as everyone at the Centre we express our sincere gratitude towards all contributors for their willingness to share their thoughts on and memories of Beyers Naudé with the readers of this book. Thank you also to everyone who over time donated to the Centre's archives the valuable material on the life and work of Beyers Naudé that has been republished here; to Wikus van Zyl, publisher at AFRICAN SUN MeDIA, for his indispensable guidance and patience regarding the technical aspects of compiling the publication; and Mrs Felicity Grové for painstaking hours of transcribing some of the lectures and addresses contained in the book. Finally, a special word of gratitude goes to Dr Hans Snoek and Dr Bert Kling of Kerkinactie of the United Protestant Church in the Netherlands, whose generous financial assistance made this publication possible.

$L D$ Hansen (editor) 


\section{FOREWORD TO THE SERIES AND THIS PUBLICATION BY THE MOST REVD NJONGONKULU NDUNGANE, ANGLICAN ARCHBISHOP OF CAPE TOWN}

Beyers Naudé was a remarkable man, and he has left us a remarkable legacy. This book and those to follow in this series on public theology will help ensure that this legacy is not lost, but instead remains a firm foundation on which we can build.

When we celebrated Oom Bey's 89th birthday with a symposium at the Beyers Naudé Centre, I was particularly struck by four lessons we should learn from him.

First, there was the nature of his leadership. He had that critical ability to take people where they had never gone before. My hope is that through this book and this series of publications and the work of the Centre, all of which are associated with his name, we shall strengthen this important aspect of leadership training in our churches and in our seminaries.

Secondly, the story of Oom Bey is the story of the human capacity to change. More than that, it is also the capacity to effect change at both a personal and public level. This is a source of hope for the world. Our future leadership must live with confidence in this God-given capacity for change.

Human history prepares us for specific roles. This is the third lesson we must take to heart. I always say that there is no such thing as coincidence - rather, there are "God-instances", which transform our lives. Encountering Oom Bey transformed the lives of those who met him - and I have no doubt of his capacity still to transform the lives of those who meet him through these pages and the subsequent publications.

Change, and yet consistency, were both markedly present in his own life. On the one hand, he never left the Dutch Reformed Church; on the other, he was open to the Spirit of God, the Spirit of transformation, for our God is a God who consistently and constantly moves the goalposts. Beyers Naudé's whole life was one of learning from this, a demonstration of the vital lesson of openness to the forces that surround us. As his friend Margaret Nash reminded us at the birthday seminar, the best way to experience this was to take up the invitation to "Come and see!" - to come and see what the Lord was doing in communities and situations way outside our own. Such plunges, immersing ourselves in new experiences beyond our comfort zone, are very important. I found this myself when, having been appointed a commissioner in the National Poverty Hearings in this country, I encountered a depth of poverty I had never previously seen, in the faces of the women, children, elderly and people with disabilities whom I met. In my book of values no-one should get preferment or leadership without having taken that plunge, having had an experience of what it means to be on the other 
side, on the downside of the economy. My hope is that the publications in this series will also serve, in a way, as opportunities for such plunges and immersion into the thoughts and experiences of others beyond our comfort zones.

Fourthly and lastly, as Carel Anthonissen reminded us at the abovementioned occasion, Beyers kept on crossing frontier after frontier. And the question that we need to be asking ourselves time and time again is: What are the frontiers that we need to be crossing? What are the new roads that we need to be travelling together? May we find in this series answers to these crucial questions, too.

Reflecting on this great man and how he crossed frontiers, I am struck by the need we have, as people of South Africa, and in particular as South African churches, to be facing public issues together. It is true that we have attained political liberation, but we still have to achieve economic transformation. And we need to engage with that and with the issue of reparations. Poverty and inequality are major challenges before us. We cannot merely leave it to politicians to respond. Churches must engage in discourse, in partnership with academia, in analysing and addressing the social and political situation of our land and in this endeavour too this series could offer an important forum for discussion.

We live in a country of contrasts, where there are the super-rich as well as the super-shacks of the informal settlements. The extent of the disparity was an eyeopener to me (and I thought I knew the settlements of Cape Town). During the 2004 election I was a monitor and went for the first time to a place actually called Super Shack in Joe Slovo in Langa. It was a completely different world and I invite you to come in your $4 \times 4$ and see Super Shack for yourself. You will be a different person when you leave.

An important part of my ministry is advocacy for the implementation of development goals, for human rights, and for maintenance of the rule of law all over our continent and our world. For the church to do this, we need a public theology that defends our humanity. This, I think, is at the heart of what Oom Bey was about - not least in his preparedness to address the pseudo-theologies that existed at that time. They are still with us today, for example, in the pseudogospels that result in right-wing fundamentalism and that pose a trap to so many round the globe.

One of our greatest needs is to develop an ethic of living with others who differ from us. Within the churches this is an issue that goes far wider than the current debates on human sexuality. How do we - how should we - handle disagreements? This is of major importance in a world that too often says, "You are either for us or against us", and that insists that only one view is correct.

Oom Bey's life illustrates how we can handle to good effect a leadership from which others dissent. How do those of us who are in positions of official leadership handle views which differ from ours? How do we deal with criticism of leadership, 
and people who disagree? As we address this within the church, we must also engage in wider public discourse, for example, by using those opportunities created for such discourse through this series and so help ensure that the Constitution, which makes such excellent provision for living with diversity, is a living reality. We must contribute to building a vibrant civil society that sustains and promotes this understanding of democracy.

John de Gruchy, in his address at the abovementioned occasion, spoke of Beyers Naudé's struggle in his lifetime to discern between true and false patriotism. We are at the stage in our country where all of us also need to address questions of true patriotism and false patriotism. We must maintain a true history too, because some reductionism is creeping in. We all know that history is written by the winners. It is the responsibility of academia and institutions like the Beyers Naudé Centre, and of this series of publications as one of its means, to maintain authentic leadership, authentic history, which affirms a place for everyone.

This collection of essays, which constitutes the first title in this series, provides rich resources for taking forward the work of Beyers Naudé and the example of his life. Many of the writers were close friends of his, some through the most difficult of times. In this regard I think of the words of friendship of Desmond Tutu, who found in Beyers Naudé a friend in the most unlikely segment of the South African community; I think of the words by Carel Anthonissen on the mentorship of Beyers Naudé, a mentorship that I am sure extended to many within and outside Beyers Naudé's own denomination; I also think of Beyers Naudé's words of encouragement and inspiration during the most difficult days of the struggle, as recalled by Allan Boesak. Some of the contributions here reflect rather on his personal life and influence, though these too are words of friendship, friendships that were sometimes forged in difficult times. Examples can be found in Margaret Nash's recounting of the story of the Christian Institute and Hannes Adonis's essay on the influence of Oom Bey on the founding of the URCSA. Others - Denise Ackermann, John de Gruchy, Nico Koopman and Christoff Pauw - engage with his public theology and the lessons it holds for us in South Africa today. Martin Rumscheid's reflections on the similarities between the situation in which the German church found itself under National Socialism and that of the churches in South Africa under apartheid, and the similarities between the theological ideas of Karl Barth and the actions of Beyers Naudé, remind us that the latter's influence and the lessons we have learned and still learn from his life are not restricted to South Africa.

Recalling again Margaret Nash, I too want to stress that we also need to live holistic lives, engaged with the realities of the world around us. Now that political change has come, we cannot afford to become complacent. Allan Boesak reminded us that to have met Beyers Naudé was to have been confronted with choices. And we too must make a conscious choice about the road we wish to follow. The life 
and work of Beyers Naudé as found in this book will be one of our best guides to the road ahead.

The choice is ours. I am reminded of the words of one of my greatest heroes, Mwalimo Nyerere, who used to say "To plan is to choose." Let us choose to go forward together for the good of all.

Cape Town, July 2005 


\section{Introduction}

The enigma of Beyers Naudé, who passed away in September 2004, lies in the seemingly contradictory position in which he, formerly an Afrikaner nationalist, a member of the Afrikaner Broederbond (AB) and a moderator in the powerful Dutch Reformed Church (DRC), found himself from 1963 onwards. When faced with the choice between the position as director of the Christian Institute (CI), an ecumenical organization that he co-founded, and his position as moderator of the Southern Transvaal Synod as well as his status as minister in the DRC, he chose the former. In a sermon he gave on 22 September of that same year he justified his decision, arguing that for him the choice was not between the DRC and the CI, but that it was "a choice between obedience in faith and subjection to the authority of the church. And by unconditional obedience to the latter, I would save face but lose my soul" (Naudé, in Ryan 1990: 81).

Amidst the storm that had erupted over his head Naudé took up the directorship of the CI. For the next fourteen years he had to continually adapt to the severe difficulties and challenges of this new ministry - not least to the challenges that black thinking put to his Reformed and scholarly theology - but, in so doing, demonstrating his "remarkable propensity for change" (Villa-Vicencio 1985: 11). During this time the CI increasingly aligned itself with the liberation struggle and by 1977 the government became convinced that the CI had become too dangerous and it was banned. Naudé, together with a number of other staff members of the $\mathrm{CI}$, were served with banning orders. He was restricted for five years, but the banning order was eventually extended until it was unexpectedly lifted in 1984 . How, to echo Charles Villa-Vicencio (1985: 4), did this prophetic figure "come from the womb of a narrow and exclusive form of Afrikanerdom to become what he is, an Afrikaner with a broad ecumenical vision and an uncompromising global perspective on life?"

\section{Biography of a nationalist}

Beyers Naudé's dramatic resignation as DRC minister in 1963 came after years of doubt and fear. Fifteen years earlier he followed the AB in fully supporting the rise to power of DF Malan's National Party, even if his unease with the biblical justification of apartheid grew increasingly stronger. At that stage, however, to

1 Christoff Pauw is a doctoral student in theology at the Free University of Amsterdam and a researcher at the Beyers Naudé Centre for Public Theology. 
take a public stand in direct opposition to the race policies of his government, his church and the $\mathrm{AB}$ was a bridge too far. He had encountered enough warnings from colleagues in the church and the $A B$ to realise that speaking out would place his future in grave jeopardy. In an interview with Colleen Ryan (1990: 73), Beyers Naudé explains the hegemony of Afrikanerdom as follows:

"An ordinary Afrikaans child is born in a very conservative, deeply religious Afrikaner home. His parents have their set of religious, political, moral and social values. The child attends an Afrikaans school where the vast majority of the teachers are verkramp or very, very conservative.

Even before he goes to school, the child moves into an Afrikaner church, normally a conservative, Afrikaans-speaking community where the minister preaches the gospel according to Hendrik Verwoerd or John Vorster or whoever is there at the time. So his thinking, up to the time he leaves school, is indoctrinated in every respect. ... If the child is privileged enough to go to university, there is a 95 per cent chance he will go to an Afrikaans university. There at least, there is a little stretching of the mind, but the majority would not be influenced to such a degree that they would be prepared to make that break.

After the person's return from university, he moves directly into a privileged Afrikaans community, as teacher or a businessman. A few may deviate, fall in love with an English-speaker perhaps, but that is the exception. The others who don't go to university, the vast majority, find their employment in some form of Afrikaner community or government institution. So where is the opportunity to break through this whole thinking? It is such a close-knit community. The bond is strengthened by the father, the Broederbond, the church, the teachers."

This description could be seen as a fairly accurate rendition of the first forty-five years of Naudé's life. He was born on the $10^{\text {th }}$ of May, 1915 to Jozua Francois Naudé and Adriana Zondagh Naudé (née Van Huyssteen) in Roodepoort. His father, Jozua, was a minister and an Afrikaner freedom fighter. He settled in the Boer republic of the Transvaal in the late 1890s as teacher at a church school in Germiston. When war broke out with Britain in 1899 he fought side-by-side with the famous Boer general Christiaan Frederik Beyers and ministered to the Boer forces. After the war he decided to study theology at Stellenbosch. During this time he married Ada (as she was known) in 1906. Upon completion of his theological training in 1909 he received calls from various congregations, but he chose to become superintendent of a work colony for poor bywoners (dispossessed white tenant farmers) in the Orange Free State. 
His commitment to helping dispossessed Afrikaners, impoverished by the war, proved strong, while his anti-imperialist stance never diminished. From 1911 he served in the congregation of Roodepoort, one of the many struggling Afrikaans communities that were starting to campaign for Afrikaner rights. When the same General Beyers and others rebelled against the call of the government of the newly established Union of South Africa to fight alongside the British Army against the German forces in German South West Africa, now Namibia, Jozua came out in full support of the rebels. General Beyers had to flee and he drowned while crossing the Vaal River in December 1914. Jozua was deeply shocked by his friend's death and honoured his memory by naming his second son Christiaan Frederik Beyers Naudé.

Jozua was a founding member of the Afrikaner Broederbond (AB) and was elected as the body's first president in 1918. The AB sought to promote the interests of the Afrikaner people above other groups in South Africa by reconciling "all Afrikaners in a single brotherhood - an organisation in which Afrikaners could find each other in the midst of great confusion and disunity" (Ryan 1990: 10). The family relocated to Piet Retief in 1919 and subsequently to Graaff-Reinet in 1921, where Jozua served a large congregation and established the first Afrikaans school in the Cape Province.

In 1932 Beyers and his elder brother Joos left home to study at Stellenbosch University. Although he wanted to study law, he (like his brother) had little choice but to study theology, since ministers' sons qualified for a theology bursary. He envisaged switching to another degree after three or four years. After his B.A. he enrolled for an M.A. in literature and wrote a thesis on Afrikaans poetry. When the time came to decide about his future, he nevertheless felt drawn to complete his theological training and entered the Theological Seminary of the DRC in 1936.

He expended very little energy on his theological studies and rather devoted his time to other student affairs such as the debating society (where one of his main opponents was John Vorster, who would later become Prime Minister) and the Berg- en Toerklub (the mountain hiking club). He was also primarius (head student) of his residence Wilgenhof and president of the Student Representative Council. The only inspiring lecturer for him was Professor B B Keet, who taught ethics and dogmatics, and who opposed the impending racist theology of the DRC. Yet, despite his independent and moderately liberal stance on matters, Beyers never shed his nationalist inclination.

During his years at Stellenbosch Beyers met his future wife Ilse Weder. She was a daughter of Moravian missionaries at the Genadendal mission station. He often visited there over weekends and was struck by the open relationships that existed between the German missionaries and the coloured inhabitants of Genadendal. Beyers's mother was against their relationship as Ilse's father was 'merely' a missionary and not a DRC minister. Ada even sent Beyers's younger sister to 
Genadendal over Christmas of 1937 to discourage him from his plans to become engaged to Ilse. He was not persuaded and married Ilse on 3 August 1940 in Genadendal before a congregation of coloured and white people.

Beyers entered the ministry in the DRC in 1940 in the congregation of Wellington. This started a twenty-three-year career in the DRC and, despite his earlier doubts about a career in the church, he enjoyed the pastoral duties, committing himself especially to youth work, evangelism and mission work. Already during his first year, his leadership potential was noticed and the Broederbond, which had meanwhile expanded into cells across the country, offered him membership in the organization. He proudly accepted, following in his father's footsteps, committed to the cause of Afrikaner nationalism.

In 1943 he accepted a call to the little town of Loxton. Here perhaps the first traces of doubt about the nationalist racial policies started to trouble him. He occasionally preached at the mission church, in the separate coloured community, in Loxton and was upset by the utter poverty in which this community lived - particularly in contrast to the Genadendal community, which he had come to know (Ryan 1990: 33). However, despite his reservations about the apartheid policies of the National Party, he was jubilant when D.F. Malan's party defeated the United Party of General Smuts. By this time Beyers and Ilse, with their first two children, had moved to the Transvaal, where he served in the Pretoria South congregation from 1945. In 1949 he became student pastor in Pretoria East.

\section{Shaping an identity of dissent}

A number of important events took place in Naudés life over the course of the 1950s that would shape his eventual stance against apartheid. His emerging ideas placed him amongst a small but growing group of young Afrikaner theologians who shared increasing misgivings about the "Afrikaner Nationalist-Reformed church paradigm" (Bosch 1985: 68). Many of these dissident voices were strongly shaped by Reformed evangelicalism - a theological current that had been dominant in the DRC since the $18^{\text {th }}$ century ${ }^{2}$ - and, through a commitment to mission, contact with the black so-called "daughter" churches of the DRC. In Naudé's case an emerging ecumenical awareness also brought him to question the DRC's growing self-isolation. Bosch maintains that, although Naudé "only very gradually emerged as the major challenger of the system from within the Afrikaner churches", many

2 Bosch (1984: 25-32) identifies three major forces that shaped Afrikaner civil religion between the late $18^{\text {th }}$ and early $20^{\text {th }}$ century, namely Reformed evangelicalism (as introduced by Andrew Murray, Jr), Kuyperian neo-Calvinism, and neo-Fichtean romantic nationalism. According to Bosch (1985: 68), Beyers Naudé and the younger theologians of the 1950s and 1960s came out of the evangelical tradition - yet often displayed the paternalistic missionary ideals of a spiritual calling to convert black people, coupled with the conviction that missionary work will in the long run materially benefit the Afrikaners (see also Durand 1985: 43-45). 
dissidents would come to rally around him in the late fifties and the early sixties (1985: 68).

One of Naudé's colleagues in the Pretoria East congregation and a contemporary from his student days was Dr Ben Marais, who had already started to voice his opposition to the biblical defence of apartheid in the church. After a study of racism in North and South America and a visit to the WCC and to various leading theologians (amongst others Karl Barth, Emil Brunner, JH Bavinck and Hendrikus Berkhof), Marais published Die kleur krisis en die Weste (The colour crisis and the West) in 1952. By today's standards the book may be judged "patronising and even reactionary" (Villa-Vicencio 1985: 7), but at the time his critique of segregated churches sent shockwaves through the DRC and the AB. Despite the objections against the book, Naudé studied it and, although he disagreed in certain respects, he was struck by so many leading theologians' condemnation of apartheid (Naudé 1995: 38-39). The fact that his favourite professor, B B Keet, came out in strong defence of Marais also had an impact on him. At the same time Naudé clearly saw how vehemently Afrikaners could react to any critique of apartheid.

One result of all this was that Naudé vowed to improve his knowledge of theology and for the first time seriously considered the works of Karl Barth (who was at the time disregarded in DRC theology) and other contemporary German and Dutch theologians. It was during this crucial period that he undertook an extensive sixmonth overseas study tour to Europe and North America as chairperson of the Kerkjeugvereniging, a Christian youth body that he helped establish as student pastor. The aim was to gather ideas for youth work, but wherever they went people questioned them about the political situation in South Africa. Initially Naudé tried to defend apartheid, but soon realised that his theological arguments were flawed and easily refuted. He realised that apartheid could not be justified by scripture. ${ }^{3}$ In their final report of the tour, however, he made no mention of this new awareness. He felt incompetent to take up the task and fearful of the consequences should he speak out. ${ }^{4}$

In 1955 Naudé accepted a call to Potchefstroom, where he became acutely aware of yet another inhibiting factor: his pastoral sensitivity. He ministered to working

3 "I used all the arguments, all the references in the Old Testament, I knew them by heart, the whole lot of them. But I realised very soon that I was up against theologians who could shoot down the one straw doll after the other. I became increasingly cautious about using these arguments, realising that something was wrong...I was led to the conclusion that there was no way in which the policy of apartheid could be justified on scriptural grounds. In this process I had to overcome all the accepted views, traditional outlooks, deep feelings of loyalty, and to see that this was essential if I wanted to remain obedient to the call of Christ and to the truth of the gospel" (in Ryan 1990: 38).

4 "I felt I was theologically inadequate ... and I was still a member of the Broederbond. ... I began to see if I could find allies within the NGK [DRC], ministers who could be convinced, because I knew I was up against an ideological barrier that would be very difficult to break. ... But it was a very painful process, and I think fear certainly played a very large part at that stage in my life. I began to realise something of the price that would have to be paid" (in Ryan 1990: 38-39). 
class people and realised that "our Afrikaner people of the platteland" (rural areas) would not be able to comprehend a critique of apartheid and that his misgivings about the biblical justification of apartheid "would come as a terrible shock" to them (in Ryan 1990: 41). Throughout the fifties Naudé also remained a loyal member of the Broederbond. Yet, his doubts about apartheid never left him and, after he had read B B Keet's short 1955 book Whither, South Africa? (which also powerfully challenged the biblical justification for apartheid), he was determined to seek clarity on his church's relationship with apartheid. ${ }^{5}$

A decisive event during his years in Potchefstroom was the meeting of the Reformed Ecumenical Synod (RES), an international ecumenical body, which took place there in August 1958. He attended the public sessions and was deeply troubled to notice the gulf that had opened between the DRC theologians and the world Reformed community on the matter of church and apartheid (Ryan 1990: 46). He describes the RES meeting as decisive for his conviction that his church was gravely mistaken in its biblical defence of apartheid. He took up the matter privately with trusted friends in the ministry, and even with other Broederbond ministers. More often than not the replies that he received came as warnings: not to "play with fire" and ruin his career with foolish declarations; that the "time was not yet ripe" for such statements (Naudé 1995: 43).

By 1958 Naudé had been elected as assessor or vice-chairman of the Transvaal synod. Young ministers who had known him as students during his time in Pretoria felt encouraged to seek his advice on their own reservations about apartheid. Naudé came to hear of the problems and frustrations of black communities from missionaries such as Chris Greyling, Francois Malan, Charl le Roux and Gert Swart.

"They told me about the problems they were experiencing and about the growing resistance of African, Coloured and Indian Christians to the stand the white NGK [DRC] was taking on apartheid. These people were challenging the white ministers by saying, 'How do you justify what is happening to us on the basis of Scripture?' The ministers invited me to come and share their experiences with them. And when they told me what they were experiencing, I said to them: 'I have to accept that you are telling me the truth, but I cannot believe it.' And so they invited me to come and look for myself. And I did. And what I found was a shattering experience" (Naudé, in Ryan 1990: 47).

5 It must be noted that, despite their criticism, Keet and Marais still harboured ideas about race segregation, arguing that if apartheid is to be justified, this must be done on pragmatic grounds. Nevertheless, their condemnation of biblical apartheid prepared the way for a dissident like Naudé "to rid himself of the shackles of a deadly and dangerous ideology, enabling him to go much further than they had ever dreamed of doing" (Durand 1985: 47). 
Naudé went on four or five visits to segregated Indian townships, to black mining compounds and to coloured slum neighbourhoods, experiencing the awful division, strife and hardship that apartheid had brought to people's lives. He told himself that if this is what apartheid is all about, it is evil, it is inhuman, it is something that can never be supported. He visited the South African Institute of Race Relations (SAIRR) and for the first time studied the apartheid race laws. "It brought me to the conclusion, not only on theological grounds, but also on practical grounds, on the grounds of justice, these laws were even less acceptable" (in Ryan 1990: 48). He knew that the church's race policy had to change and that in order to accomplish this he would need to gather support from enough fellow ministers to lead such change. When he received a call to the new Aasvoëlkop congregation in Johannesburg, he used the opportunity of being back in the city to initiate a number of Bible study groups with the aim of leading the church away from apartheid. Initially these consisted of only DRC ministers, but soon black and coloured ministers, also from other denominations, joined some of the groups.

If critical voices from within the DRC were tolerated in the fifties, this was brought to an abrupt end after 1960. The Sharpeville massacre of 21 March 1960 prompted a new and more activist phase in black resistance to apartheid and focused world attention on the situation in South Africa. The English churches (especially the Anglican Church) attacked the DRC for supporting apartheid. The World Council of Churches (WCC) sent a delegation to meet with its South African member churches (which included the Transvaal and Cape synods of the DRC). Their aim was to address the growing rift between the churches and to discuss the political situation in South Africa. A week-long conference was planned for December 1960 in the Johannesburg suburb of Cottesloe and Naudé was nominated to represent the Transvaal synod. For Naudé this was clearly an important opportunity to voice his opinions, albeit still very carefully. Up to the start of the conference his public statements were still very loyal to and defensive of the image of the DRC and his political views were conservative and paternalistic.

The conference would ultimately be deemed a failure, but for Naudé and his Afrikaans colleagues this was their first real ecumenical contact with white and black churchmen from the Anglican, Methodist and other English churches. Some of the relationships that he built up, amongst others with Dr JB Webb of the Methodist Church and, especially, Fred van Wyk of the South African Institute of Race Relations, would become important for his later work in the CI. The eighty delegates (of whom twenty were from the DRC) decided to draw up a statement of their decisions, which was to be released after the conference. The statement was moderate but far-reaching given the situation in South Africa. ${ }^{6}$ It affirmed that all

6 The statement was largely based on a study document that was prepared by the Cape delegation of the DRC in preparation for the conference. This is significant, since it shows that within certain DRC 
races had equal political and social rights, and that nobody could be excluded from any church on the basis of race. The DRC delegates realised that this would be read as a rejection of the government's policies and decided to issue a separate statement explaining that by signing the conference statement they were in fact not giving up support for the government's apartheid policy (Ryan 1990: 55-61).

When the conference statement was released, however, this reservation was not sufficient to stem the tidal wave of rejection expressed in the Afrikaans press. Prime Minister HF Verwoerd settled the matter in his 1961 New Year's message, when he said that the statement expressed the views of individuals in the church and that the synods will have the final say on the matter. The AB followed this up by informing its members in a circular that the Broederbond executive had rejected the Cottesloe statement. Not surprisingly, the April 1961 meeting of the Transvaal synod did not re-elect Naudé as moderator and univocally condemned Cottesloe. The Cottesloe delegates were summoned to the front of the assembly hall and asked to explain their support for the Cottesloe statement. Of the six responses, five were apologetic or even openly critical towards Cottesloe. Beyers Naudé saw this as a turning point in his life:

"I had to decide - would I because of pressure, political pressure and other pressures which were being exercised, give in and accept, or would I stand by my convictions which over a period of years had become rooted in me as firm and holy Christian convictions? I decided on the latter course ... I could not see my way clear to giving way on a single one of [the Cottesloe] resolutions, because I was convinced that they were in accordance with the truth of the gospel" (in Ryan 1990: 66).

The synod voted on Cottesloe. It rejected all its findings and reaffirmed its support for the government's policy of "differentiation." It also decided, without debate, to withdraw the Transvaal DRC's membership of the WCC. Six months later, at their synod, the Cape DRC followed suit. The DRC had now severed all ecumenical ties, both inside South Africa and abroad.

\section{Anti-apartheid prophet}

"[Peter and the] apostles rejoiced that they were counted worthy to suffer for their Master, and they continued with their teaching - disobedient yet at the deepest level obedient, unfaithful, yet faithful at the deepest level."

Beyers Naudé, sermon on Acts 5:17-42 delivered on 22 September 1963.

circles there was a growing concern about some of the apartheid policies of the government. Sadly, this voice would soon be effectively silenced. 
After the 1961 Transvaal synod, where Naudé was the sole delegate to stand by the findings of the Cottesloe report, he faced an increasingly uncertain future. He was still deeply committed to his church and his people, but he was unsure how they would react to his stance of conscience. Shortly afterwards Naudé arranged for the WCC representative Robert Bilheimer to address one of the ecumenical Bible study circles. Bilheimer emphatically expressed the need for ecumenical contact between the races, stating that it was "of crucial importance for people across the colour line to get to know and trust each other, as happened at Cottesloe, because without trust there is no hope" (in Ryan 1990: 68, emphasis added).

Naudé discussed this need with a number of trusted Bible study friends - amongst others Albert Geyser of the Hervormde Kerk, Fred van Wyk of the SAIRR and Willie Jonker, who had been elected aktuarius (registrar) at the 1961 Transvaal synod. They decided to launch an Afrikaans theological journal that would address apartheid's violation of the gospel and promote change in the DRC towards greater unity with other churches. Naudé was chosen as editor. The first issue of Pro Veritate was prepared in Naudé's parsonage, the friends using their personal savings to cover the expenses. It appeared on 15 May 1962 and was sent to DRC ministers countrywide, in the hope that it would attract enough subscriptions to continue monthly issues. Continue it did, but among a different readership than Naudé had intended. Broederbond members soon voiced their protest against the journal. Reaction from the church newspaper Die Kerkbode, which had been vociferous about Cottesloe, was hostile, and the Afrikaans secular press followed its example.

Naudé and his colleagues were alarmed by this determined reaction. They were concerned that Afrikaners who did not support apartheid would have nowhere to voice their opinions. This led them to consider establishing an independent ecumenical organisation where Afrikaners could investigate alternatives to apartheid theology. Naudé envisaged an institute that would "organise and initiate courses, conferences, Bible study weeks and discussions" between Christians from different churches and races, as well as "the creation and building of ecumenical study groups in various centres [and] the distribution of factual information on the ecumenical movement" (Ryan 1990: 71).

Naudé's congregants at Aasvoëlkop - like probably the majority of Afrikaners were simply baffled by these endeavours. Those DRC members and theologians who did comprehend or support Naudés motives and concerns often appealed to him to work for change "from the inside" rather than disrupting the - albeit lengthy - process of change and in the event jeopardising his own future. But for Naudé an ecumenical body was vital for the church and he pressed ahead. After a number of preparatory meetings over the course of a year with a wide range of church leaders, the Christian Institute of Southern Africa was finally established in August 1963. Membership would be voluntary and open to any Christian and 
would, according to its official press announcement, "in no way detract from the loyalty of any member to his own church or creed" (in De Gruchy 1985: 16). Fred van Wyk was appointed as administrator and Naudé was offered the position of director. However, by the end of 1963 events in the DRC had caused this offer to be of major consequence for Naudé's relationship to his church.

Against Naudé's wildest expectations he was elected as moderator of the newly formed regional synod of the Southern Transvaal in March 1963. This was all the more surprising as he had just handed in his resignation from the Broederbond - a step that sent shockwaves through the Afrikaner establishment. ${ }^{7}$ He was uncertain how his election could have come about, but made sure to chair the fourteen-day synod meeting with the utmost dedication and composure. However, on the second last day the matter of Pro Veritate was tabled. Naudé stepped down from the chair for the discussion and listened as one speaker after another opposed this new critical voice from outside the church. A motion was passed that office-bearers dissociate themselves from Pro Veritate and rather support the church's own newspaper. Naudé was called on to resign as editor of the journal, upon which he responded that he needed time and would respond within a few weeks. He started to suspect that his election as moderator had been a ploy (possibly by the $\mathrm{AB}$ ) to persuade him to quit his protest against apartheid and follow the illustrious career that his church could offer him. However, since the Cottesloe synod Naudé's mind had been made up that he would no longer compromise his own convictions and in the editorial of 15 May 1963 he announced that he would not resign as editor (Ryan 1990: 75-77; Naudé 1995: 65-66).

A few months later, when Naudé was offered the position of director of the CI, a storm broke loose over his involvement in these "extra-ecclesial" bodies. Even his own congregation's church board requested that he resign from the $\mathrm{CI}$ and Pro Veritate. His brother-in-law, Dr Frans O'Brien Geldenhuys, who had supported Naudé through much of the preceding events, pleaded with him to not accept the CI position but to try, hard as it might be, to change the thinking of the church from within. His response was that he would only consider declining the position if he could gather enough support to take on this challenge from within - if there would be, in his words, "enough ministers who would be prepared to stand with me, not by me, but with me, in order to challenge the NGK on our biblical understanding of its prophetic task at this point in history" (in Ryan 1990: 79). Two days before Naudé had to make his decision on the directorship, he called Geldenhuys and asked whether there were, say, ten ministers who were prepared to commit to such a course. His brother in law answered, "But, Bey, you know that

7 It came to light shortly afterwards that Naudé had lent secret AB documents to Albert Geyser, who was carrying out a study on the Broederbond. This in itself was a breach of the code of conduct of the Broederbond, but Naudé's action was publicly raised to the level of Afrikaner treason when Geyser photographed the documents (without Naude's consent) and sent them to the English Sunday Times newspaper, which subsequently ran a series of exposés on the AB. 
after all that has happened since Cottesloe it will be virtually impossible to find ten such brothers." For Naudé this was enough of an answer. He would take up the position at the CI. It is remarkable how he employed the widely held "insideoutside" metaphor to make the decision. He transforms it into a pragmatic principle: if there is enough support amongst the ranks that will equip the agent of change, then change from the inside is preferable; however, where the support is lacking and such change is unlikely to occur, the only truthful route is to step outside the boundaries and gather external support for one's endeavours.

On 22 September 1963 he delivered the famous sermon based on Acts 5:29 to inform his congregation of his decision. ${ }^{8}$ As Naudé would be taking up employment outside the DRC, he had to apply to his church for retention of his status as minister. His request was refused without reason. He understood then that his resignation from the congregation would also mean the end of his ministry in the DRC. He gave an emotional farewell sermon on 3 November and the very next day started his new ministry with the Christian Institute. His inaugural address on 15 December was delivered in the Central Methodist Church in Johannesburg. It was entitled Versoening (Reconciliation). ${ }^{9}$ For many years Naudé would remain in the DRC - he and Ilse became members of the Parkhurst congregation.

Naudé had now rid himself of the shackles of Afrikanerdom and was free to pursue the struggle against apartheid with like-minded clergy. Although Pro Veritate remained an independent journal, for all practical purposes it became the mouthpiece of the CI. John de Gruchy observes that the gradual shift in the theology of the CI can be traced through a careful analysis of the journal. "It was always ecumenical in emphasis, but for most of the sixties its theological orientation was Reformed and its main source of inspiration was the Confessing Church struggle in Nazi Germany. Towards the end of the sixties until its demise, its orientation was more influenced by black and liberation theology" (De Gruchy 1985: 17). The CI can thus be characterised as a prophetic and ecumenical movement in the light of the Afrikaans churches' failure to address racism and injustice in South Africa. Naudé himself typified the CI as a step towards a Confessing Church in South Africa in an article in 1965. It was initially primarily driven by and directed towards white anti-apartheid concerns. However, as the Afrikaner establishment mounted its criticism and rejection of the movement, and particularly that of Naudé, and as CI members were increasingly exposed to the particular needs of black churches, its direction gradually changed to a more contextual theology.

The history of the CI from its inception in 1963 to its demise in 1977 has been well documented in a number of publications, most notably the in-depth 1982 study,

8 See pages 25-29 of this publication - ed.

9 See pages 139-142 of this publication - ed. 
Church versus State in South Africa by Peter Walshe. ${ }^{10}$ The Institute became integrally bound with the church struggle in South Africa. This was powerfully demonstrated in 1968, when it publicly issued The Message to the People of South Africa with the newly formed South African Council of Churches (SACC). The CI decided to affiliate with the SACC and the two bodies shared the same office building in Braamfontein. The Message asserted that the gospel of Christ cannot tolerate the ideology of apartheid and called on Christians to recognise the imminence of the Kingdom of God within history and the appeal that this implied for establishing justice for all people - not merely through charitable action but also in public policy.

Later that year the CI and the SACC also sponsored the joint Study Project of Christianity in Apartheid Society (SPROCAS). This project, which Naudé (1995: 89) calls possibly the single most important product of the CI, was an attempt to put the precepts of The Message into practice. Over a period of two years SPROCAS produced a number of publications through six independent commissions (all-inall involving 130 people) that dealt respectively with the themes of education, economics, society, politics, law and the church.

Both The Message and SPROCAS were, however, still undertaken with mainly white interests in mind and, according to Walshe, adopted an essentially paternalistic stance: "a call to white South Africans to establish justice for the poor" (1995: 54). The approach was more academic than activist and black leaders were not particularly enthusiastic about the outcomes. The CI therefore had to endure criticism not only from the right - the Afrikaans press continued to attack what it called "leftist" and "communist" attempts to destabilise society - but also from the left, whence suspicions of white vested interests and criticisms of a too nonconfrontational stance came (Naudé 1995: 90-91; Walshe 1995: 55).

As the call for action increased, also from foreign donors, on which the CI was always very dependent, the CI started to transform its thinking. The 1970s saw increasingly successful strike actions by black trade unions, out of which, in part, grew the Black Consciousness Movement (BCM) in townships across South Africa. The BCM not only rejected apartheid, but also fundamentally called liberal capitalism and its exploitation of black labour into question. During the same period the WCC launched its Programme to Combat Racism (PCR), which made grants to exiled liberation movements such as the ANC, the PAC and SWAPO. This raised the matter of violence and the church for Christians across South Africa. The CI started to engage with the theological currents in the BCM. In this way Naudé met with black Christian leaders such as Oshade Phakathi, Allan

10 In 1995 Walshe published a follow-up entitled Prophetic Christianity and the Liberation in South Africa, which traces the anti-apartheid church movement from 1977 to 1990. Other histories of the Christian Institute include those by John De Gruchy (1985: 14-26), Peter Randall (1982: 28-47), Colleen Ryan (1990: 96-192), Brian Brown (1985: 24-33) and Naudé's autobiography (1995: 83-108). 
Boesak and Manas Buthelezi, as well as with other BCM leaders such as Steve Biko, Malusi Mpulwana and Barney Pityana. He also became personally involved in assisting young people to flee the country and in spreading ANC literature such as the Freedom Charter (Naudé 1995: 93).

The challenge to become involved in the black struggle for liberation rather than the struggle to change white attitudes led to the formation of SPROCAS II, the Special Programme for Christian Action in Society. Out of SPROCAS II grew the successful Black Community Programmes under directorship of Bennie Khoapa. In a time when blacks were wary of participating with whites in the struggle against apartheid, the CI and Naudé managed to gain their trust. This trust was, ironically, strengthened when the apartheid regime started to take action against the CI. The Security Police raided CI offices, confiscated passports and CI workers were increasingly being detained and banned. Black people saw white people suffer for the sake of black liberation.

In 1972 the state established the Commission of Enquiry into Certain Organisations (Schlebusch/Le Grange Commission) to investigate the University Christian Movement (UCM), The National Union of South African Students (NUSAS), the South Africa Institute of Race Relations (SAIRR) and the CI. Naudé refused to testify before the Commission and was subsequently charged and taken to trial in November 1973. He was found guilty of contravening the Commission Law and sentenced to a fine of R50 or a month in jail. On appeal, and only after a lengthy three-year trial, the Transvaal High Court, in October 1976, confirmed the previous court's decision and ratified the original sentence. Naudé insisted on going to jail in solidarity with the thousands of political prisoners who had gone before him. He spent one night in jail - where he "read the Book of Amos and slept like a rock" before Dr JHP Van Rooyen, his minister in the Parkhurst congregation, and Rev. Gert Swart paid his fine (Naudé 1995: 99-100).

By now the struggle had intensified to unprecedented levels. In June 1976 as many as 20,000 school children marched in Soweto to protest against the government's education policies. The conflict escalated to countrywide protests against apartheid. Over the course of the following year 700 people, according to the official count, lost their lives in the confrontation between protestors and state security forces. Throughout the turmoil the $\mathrm{CI}$ remained supportive of the BCM. When Steve Biko was killed in prison on 12 September 1977, the state took control and banned eighteen organisations linked to the BCM. On the morning of 19 October 1977 Naudé received a call from Helen, wife of his Cape Town colleague Theo Kotzé, informing him that "They are here; be prepared." He and Ilse drove to the Braamfontein offices where the Security Police awaited him. The Christian Institute and with it Pro Veritate had come to their end.

Naudé describes his banning period as his "seven lean years," but in many respects they were enriching and rather peaceful years after the preceding tumult. 
The government's action against Naudé, ironically, removed any last doubts that black people may have had about his trustworthiness. A restricted person was restricted to a certain area and could never meet with more than one person at any time, and certainly not publish anything or make any public appearances. Yet during his restriction Naudé received hundreds of black and white church leaders, politicians, foreign visitors and friends. He had become, in the words of VillaVicencio, "a symbol of resistance and hope" (1985: 12). He could devote much time to further theological studies and he could also spend more time than ever before with his wife Ilse. It was also during this period that Naudé decided he could no longer remain a member of a church that resisted the Christian calling for unity with its "daughter" churches on grounds of race or colour. He quit the DRC and applied for membership in the Alexandra congregation of the black Dutch Reformed Church in Africa (DRCA). In March 1980 a special ceremony was held in the church hall of the DRC Parkhurst - he was not allowed to enter Alexandra township - where the minister of his new congregation, Sam Buti, welcomed him as member.

When his banning unexpectedly came to an end on 26 September 1984, Naudé once again faced an uncertain, albeit much more hopeful, future. Shortly afterwards he was elected to the position of General Secretary of the SACC, which he held for three years. He gave countless public lectures in South Africa and abroad, calling for the liberation of South Africa's oppressed, for the unbanning of the liberation movements, for the release of political prisoners, for economic sanctions against South Africa and more. He also took part in political events, for instance attending the Lusaka meetings with members of the ANC in May 1987. During this time he was also ordained as a minister of the DRCA and played a leading role as DRCA representative in the process of unification between the DRCA and the coloured Dutch Reformed Mission Church (DRMC). When the Uniting Reformed Church of Southern Africa (URCSA) was finally established in April 1994, Naudé shared in the joy and gratitude of the delegates.

\section{A legacy of justice and reconciliation}

Unlike many other Afrikaner dissidents, including the lawyer Bram Fischer, Beyers Naudé was, as he himself has often said, fortunate to see the emergence of the "promised land". During the years after his banning Naudé received wide recognition in South Africa and abroad. He was given numerous awards ${ }^{11}$ and

11 Some of the awards that he received were the Bruno Kreisky Award (1972), the Reinhold Niebuhr Award (1974), the Franklin D Roosevelt Four Freedoms Award (1984), the Robert F Kennedy Human Rights Award (1985) the Order of Oranje-Nassau of the Netherlands (1995), the Freedom of the City of Johannesburg (2001) and the Highest Award of the Afrikaanse Taal-en Kultuurvereniging (2004). 
honorary doctorates ${ }^{12}$ and a number of collections ${ }^{13}$ and biographies ${ }^{14}$ were published in honour of his life. He has to a certain extent been "welcomed back" by many Afrikaners who had come to recognise the injustice of apartheid and questioned its biblical foundations. At its 1994 General Synod meeting the DRC offered an apology to Naudé for their rejection of his position; he was welcomed with a standing ovation. In December 2000 Stellenbosch University awarded an honorary doctorate to Naudé. A year later a new research centre for public theology was established at Stellenbosch and named after him. Naudés name had come to stand for the process of reconciliation in a formerly divided country. Under apartheid he won the trust of many black persons and became for them a symbol of hope that white people can change; after apartheid many Afrikaners also recognised in him a symbol of hope for the peaceful transformation of society..$^{15}$ The vision that he had for a just society and for an ecumenical church captured the hope of many people across the boundaries of race and ethnicity. He had earned the trust of those who strive for justice. And to echo Bilheimer's words after Cottesloe: without trust there is no hope!

History will continue to define the contribution that Naudé had made to the church and society in South Africa. A number of these can be mentioned - I want to mention three only. Firstly, his life demonstrates that it is often in the real encounter with the other that one comes to question one's own position. In an interview with Dorothee Sölle, Naudé (1986: 4-7) mentioned three decisive events or experiences that changed the course of his life, namely a growing awareness, through his interest in mission, of the emerging black voice in post-colonial Africa; his exposure to the living conditions of black, coloured and Indian communities; and the shootings at Sharpeville in 1960. Naudé's life shows that the open encounter with others is not simply an exposure of the self to the other, but it also exposes the self to the self.

A second, more concrete contribution is his theology. Although he never regarded himself as an incisive theologian, in his resistance and protest he became one of

12 Among the numerous honorary doctorates that he received are those from the Free University of Amsterdam (1972), the University of the Witwatersrand (1974), the University of Cape Town (1983), Notre Dame University (1985), Limburg University in the Netherlands (1989), the University of Natal (1991), the University of Durban-Westville (1983), the University of the Western Cape (1997) and the University of Stellenbosch (2000).

13 Charles Villa-Vicencio and Carl Niehaus (eds.) 1995. Many Cultures, One Nation. Festschrift for Beyers Naudé. Cape Town: Human \& Rousseau; Charles Villa-Vicencio \& John W De Gruchy (eds.) 1985. Resistance and hope. South African essays in honour of Beyers Naudé. Cape Town: David Philip; Charles Villa-Vicencio et al. 1985. Met de moed der hoop. Opstellen aangeboden aan Dr C F Beyers Naudé. Baarn: Ten Have; and Peter Randall (ed.) 1982. Not without honour. Tribute to Beyers Naudé. Johannesburg: Ravan Press.

14 Biographies include those of Bryan (1978) and Ryan (1990) as well as Naudé's autobiography (1995).

15 In this regard it is interesting to note the many references to his devotion to principle as, in fact, a recognizably Afrikaner trait - see, for instance Klaaren 1997: 374. 
very few Afrikaner theologians to read Karl Barth's critical theology seriously, to commit to ecumenism and to embrace the ideals of liberation theology (Klaaren 1997: 374). These theological emphases certainly stimulated much debate in the Afrikaans and English-speaking churches during his lifetime. They have since attained a measure of prominence within the theology of the DRC and certainly in the broader Dutch Reformed family of churches. Naudé's participation and commitment to the process of unification between the churches of this family can also be seen as an expression of this theological commitment.

A third contribution is the many outcomes of his participation in the struggle against apartheid. The work and influence of the Christian Institute cannot be overestimated, as the frequent references to the CI in historical accounts of the church struggle in South Africa attest. The CI also demonstrates the interesting shift in thinking of white theologians who opposed apartheid and the DRC from a rather scholarly approach - often based on the confessing church movement in Nazi Germany - to a more contextual theology that drew on black consciousness and liberation theology. Even after the CI was banned, its witness continued through key figures in both the black and the white churches, thus strengthening its form of contextual and liberation theology within the struggle churches (Walshe 1995: 57). This resulted in a prophetic theology in South Africa that took on a quite different form to, for instance, that in Latin America. Rather than creating a "third way" approach where Christian communities sought an alternative to the liberation movement, prophetic theology in South Africa identified with the goals of the liberation movement and leading church figures often played very public roles in the struggle. ${ }^{16}$ It is for this reason that Nelson Mandela could in 1992, during the - at times precarious - negotiation process for a new dispensation, call on the churches to act "as a midwife to the birth of our democracy" (cited in Walshe 1995: 147).

Naudé personally remained influential in the struggle even during his banning, not only by meeting with prominent church and political figures, but also through his symbolic presence. When the United Democratic Front (UDF), a coalition of political, church, community and cultural organisations, was launched in 1983, Naudé was named one of its patrons (Walshe 1995: 88). As soon as the restricting order was lifted, he was swept onto the public stage once again, most importantly as SACC General Secretary, where he contributed to strengthening the SACC's international ties (1995: 112-113). He also threw his weight behind such antiapartheid initiatives as the Institute for Contextual Theology, which was

16 The result of this has been multifaceted: on the one hand, the church became recognized and acclaimed as a crucial instrument in the struggle for justice; on the other hand, the close ties that were formed between the church and what would be the future government placed many churches in a post-apartheid South Africa in a precarious position with regards to their prophetic function in society. This question of what form the prophetic task of the church must take in post-apartheid South Africa is discussed more and more at church conferences and meetings. 
instrumental in the drafting of the Kairos Document in 1985, and the Durban-based pastoral centre Diakonia (1995: 116-118).

Friends, colleagues and even critics have described Naudé as a "very lovable" person with a "grit-like determination" in the fight for justice. His devotion to principle is for many his strongest quality. Some Afrikaners still call him a man led astray (often referring to his decision to "leave his church" and his "betrayal" of the Broederbond), but others have come to recognise the moral claims that he raised (and symbolically continues to raise) as the claims of a fellow Afrikaner who had shown that people can change. His is at once a practical and a symbolic contribution. Many agree that Naudé had been able to develop a remarkable balance between his evangelical roots and his sense of realism and in this never let go of his hope and his ability to imagine a future where God's justice will reign. Villa-Vicencio echoes this when he writes that for Naudé one's understanding of the Scriptures

“... must be tested within a community of people of goodwill, including both Christians and those who care not to be known as such. It must be concretised in relation to ongoing political and economic analysis, and ultimately verified in a deeply personal inner conviction. [Naudé] is today at once a deeply spiritual and a profoundly secular person. ... His is a worldly Christianity, but one deeply grounded in a very traditional understanding of theological identity" (Villa-Vicencio 1985: 8, 13).

\section{Conclusion}

The life and legacy of Beyers Naudé challenges the idea that Afrikanerdom had a hegemonic and monolithic cultural and political structure. Naturally the establishment would paint him as an exceptional case and treat him accordingly, but his resistance as such cannot be regarded as an exceptional action for Afrikaners. The commitment to cause and the devotion to principle do become remarkable, however, when the personal cost attached to such commitment and devotion is significant. This has certainly been the case in Naudé's life.

The "seemingly contradictory position" in which Naudé found himself in 1963 is therefore surprising and noteworthy, but not inconsistent with his identity as an Afrikaner who maintained his integrity beyond concern for his own future. Yet at the same time - as also demonstrated by the many tributes at his death - he remains a prototype. He represents the best of what South Africans, also Afrikaners, can be and should be. His openness to others, his commitment to Christian reconciliation and his fearless quest for justice will remain as a beacon of hope for generations to come. 


\section{Bibliography}

Bosch, David. 1984. "The roots and fruits of Afrikaner civil religion". In J W Hofmeyr \& W S Vorster (eds.) New faces of Africa. Essays in honour of Ben Marais. Pretoria: Unisa, 14-35.

Bosch, David. 1985. "The fragmentation of Afrikanerdom and the Afrikaner churches". In Charles Villa-Vicencio \& John W De Gruchy (eds.) Resistance and hope. South African essays in honour of Beyers Naudé. Cape Town: David Philip, 61-73.

Bryan, G McLeod. 1978. Naudé. Prophet to South Africa. Atlanta: John Knox Press.

De Gruchy, John W. 1979. The church struggle in South Africa. Cape Town: David Philip.

De Gruchy, John W. 1985. "A short history of the Christian Institute". In Charles VillaVicencio \& John W De Gruchy (eds.) Resistance and hope. South African essays in honour of Beyers Naudé. Cape Town: David Philip, 14-26.

Durand, Jaap. 1985. "Afrikaner piety and dissent". In Charles Villa-Vicencio \& John W De Gruchy (eds.) Resistance and hope. South African essays in honour of Beyers Naudé. Cape Town: David Philip, 39-51.

Klaaren, Eugene M. 1997. "Creation and apartheid: South African theology since 1948". In Richard Elphick \& Rodney Davenport (eds.) Christianity in South Africa. A political, social and cultural history. Cape Town: David Philip, 370-382.

Naudé, C F Beyers \& Sölle, Dorothee. 1986. Hope for faith. A conversation. Geneva: WCC Publications.

Naudé, C F Beyers. 1995. My land van hoop. Die lewe van Beyers Naudé. Cape Town: Human \& Rousseau.

Randall, Peter, ed. 1982. Not without honour. Tribute to Beyers Naudé. Johannesburg: Ravan Press.

Ryan, Colleen. 1990. Beyers Naudé. Pilgrimage of faith. Cape Town: David Philip.

Villa-Vicencio, Charles \& De Gruchy, John W, (eds.). 1985. Resistance and hope. South African essays in honour of Beyers Naudé. Cape Town: David Philip.

Villa-Vicencio, Charles \& Niehaus, Carl, (eds.). 1995. Many Cultures, One Nation. Festschrift for Beyers Naudé. Cape Town: Human \& Rousseau.

Villa-Vicencio, Charles et al. 1985. Met de moed der hoop. Opstellen aangeboden aan Dr C F Beyers Naudé. Baarn: Ten Have.

Villa-Vicencio, Charles. 1985. "A life of resistance and hope". In Charles Villa-Vicencio \& John W De Gruchy (eds.) Resistance and hope. South African essays in honour of Beyers Naudé. Cape Town: David Philip, 3-13.

Walshe, Peter. 1983. Church versus state in South Africa. Maryknoll: Orbis Books.

Walshe, Peter. 1995. Prophetic Christianity and the liberation movement in South Africa. Pietermaritzburg: Cluster Publications. 


\section{FROM THE ARCHIVES OBEDIENCE TO GOD}

Beyers Naudé

Our text this morning is taken from Acts 5:29 which reads: "We must obey God rather than men."

To understand what these words mean for the Church and for society, and also for you and me, we must begin by clearly understanding their context.

Here we see a group of men and women (actively) proclaiming Jesus Christ as $\mathrm{He}$ revealed Himself to them by the outpouring of the Holy Spirit. Their proclamation is not just a recitation of history; it is certainly history, resurrection history, but it is much more: it is a witness to Jesus Christ, as Resurrected Lord, as the Living One in their midst. And because he is alive, they experience his life in them; they experience transformation and renewal of their whole being. Their message is of Easter and Pentecost, of the gift of new, divine life affecting every aspect of human life and transforming all human relationships. Is it any wonder that this message brought many to total acceptance, but just as many others to fierce resistance?

Now the word of Scripture becomes a vivid truth of experience for the apostles: the Gospel is a sign which shall be spoken against, a savour of life unto life and death unto death, a word active and powerful and sharper than any two-edged sword. That this sword cuts two ways is clear as the opposition reveals itself - and this from the side of the high priest and the Sadducean party which called together the Sanhedrin as an ecclesiastical body, before which Peter and the apostles must present themselves - the same body, this, which condemned Jesus. The high priest is perturbed that the apostles have ignored the previous command no longer to teach in the Name of Jesus Christ: the Sanhedrin had hoped by persuasion to impose silence on the apostles. Now they accuse the apostles of disturbing the peace of Jerusalem ("You have filled Jerusalem with your teaching") and the peace of the church with a message which they classify as self-willed ("your teaching") and they reprove the apostles for trying to lay the death of this Man at their door. Had they so soon forgotten that but a short while before precisely this was the wish expressed by the people before Pilate: "Let his blood be upon us and upon our children!"

1 Translation of the sermon preached by Beyers Naudé on Sunday, 22 September 1963 at the Aasvoëlkop Congregation in Johannesburg on the occasion of his announcement of his decision to accept the directorship of the Christian Institute of Southern Africa. (Originally published by the Christian Insitute in a collection of sermons, My Decision, by Beyers Naudé. n.d.: 3-11) 
What defence can Peter and the apostles offer? Apparently the charge is well grounded. They have been disobedient. What can Peter say by way of rebuttal? How peculiar: he offers no defence whatsoever. He could, had he wished, have referred to the recent miraculous works of healing and the equally miraculous release from prison the previous night, but he does not even mention it. What he does is this: he brings them face to face with God as they have come to know him in and through Jesus Christ. Peter says, briefly and boldly: when God commands, all authorities and powers must not be obeyed. On the contrary: "Let every man be subject to the powers set over him" says Paul. However, when the will of man conflicts with the will of God, then man must realise: now I must obey God rather than man.

But how does one know when it is God who speaks? Does conscience tell us? And how do we know whether our conscience is always right? How did Peter know? How could he prove it? The fact was: he could not - he stood defenceless before his judges and before the people. The only anchor he had was the inner certainty of faith which God had given him through his Spirit - the certainty God gives to everyone who through conflict is prepared to come to total dependence on him and to be persuaded by him to that obedience which he expects of us.

In this shining certainty, the apostles now offer to their church and people in the name of the living Christ, salvation and forgiveness of sin. Their message to the Sanhedrin is: Christ is ready to make a new beginning with the ancient people of Israel: the door is still open; his grace is available (vv. 30-32). And they? What do they make of this offer?

The reaction of the Sanhedrin is immediate and sharp (v.33). The words pierce their hearts (but in quite the opposite way to that of the crowds of Pentecost) and arouse enmity and resistance, resentment and anger.

But amongst them is Gamaliel, the well-known Jewish theologian, highly respected by his people - the man to whom we usually refer as the sage counsellor of the Sanhedrin. In a way this is true: what Gamaliel says contains much wisdom and truth. But when we look more deeply, we realise that he is not concerned with Christ, the Truth and the Wisdom of God. His real concern is not for the apostles, i.e. for Jesus, but for the Sanhedrin, the Jews. He speaks a word of warning ("For if this idea of theirs or its execution is of human origin, it will collapse; but if it is form God, you will never be able to put them down, and you risk finding yourselves at war with God"), a word whose prophetic truth and import he does not appreciate - just as Caiaphas is unwittingly used by God to speak prophetically when he said of Jesus "it is more to your interest that one man should die for the people than the whole nation should be destroyed."

What does Gamaliel's advice amount to? Do you know? "Postpone the decision: do nothing now - the time is not yet ripe." I believe Gamaliel perceived the 
integrity of the apostles; I believe he felt very unhappy about the course of events in the Sanhedrin - but in his counsel he avoids a decision, and leads his people away form Jesus by a devious path!

And the conclusion of the whole matter? The Apostles rejoiced that they were counted worthy to suffer for their Master, and they continued with their teaching disobedient yet at the deepest level obedient, unfaithful, yet faithful at the deepest level.

Thus far the exposition. Now the question arises: what has all this to do with us? With you, with me, with the situation in our church, in our people, in South Africa and in Africa? I know some will say: is it not sheer audacity to draw an analogy from this story to the situation in which we find ourselves today? Only the Holy Spirit, my brethren, can persuade each one of you to what extent Acts 5 applies to our situation. As for myself, I have tried to find guidance for my own decision in other passages of Scripture, and I have tried to find reasons which would enable me to sever my connection with Pro Veritate and the Christian Institute and continue peacefully and happily with my pastoral work. But time and again sometimes with great conflict, fear and resistance in my heart - the Lord brought me back to this passage of Scripture, as if to say: whatever this text may mean for others, this is my answer for you: obey God rather than men!

And now I pass on to you the insight as God has given it to me in recent days, through many events, and sometimes with great resistance an unwillingness on my part:

The decisions of Synods, Presbyteries and Sessions, and the consequent reactions, have clearly indicated to me that, although the Synod has not in so many words prohibited pronouncements which are not in accordance with church policy and the traditions of the past, in spirit and in practice these decisions come to this: that the God-given right and freedom of minister and member to witness to the truth of God's Word in the spirit of the prophets and the reformers is so restricted that the minister of the Gospel in principle no longer enjoys the freedom to declare his deepest Christian convictions in the way or at the place and time given him by God to speak through his Word and Spirit.

Consequently the choice facing me is not primarily a choice between pastoral work and other Christian work or between the Church and Pro Veritate, or between the Church and the Institute. No, the choice goes much deeper: it is a choice between obedience in faith and subjection to the authority of the Church. And by unconditional obedience to the latter, I would save face but lose my soul.

By joining the Christian Institute, I am not leaving the Church. On the contrary, I wish, through the Institute, to serve my church in the wider ecumenical content [sic - ed.], even if my church today does not officially see it in this light, or so desire it. Nor am I abandoning the ministry of the Word - for this very reason, I 
applied for permission to retain my status in order to show my church that I did not wish to be anything other than a minister of the Word. Concerning the decision of the Examining Commission, I would only say that I regard it as unreasonable and unjustified - a decision which cannot be upheld on the basis of ecclesiastical policy nor founded on precedent. And so I pray that the day may soon dawn when this decision will be rescinded. In the meantime there is only one way for me: to be obedient to God! This is God's Word and Way for me. Therefore I must go.

But this text has a meaning for this congregation - because this step of mine affects you even though neither you nor I willed it so. You also are called upon to choose, to decide. You cannot escape it. And please note: the decision has nothing to do with my person or convictions, with my remaining with or leaving the congregation, or with your views about Pro Veritate or the Christian Institute fundamentally it concerns Christ. If so, obey his word. Do you live by his word? God will not let you go until you have chosen!

For our Dutch Reformed Church also, our text this morning has a meaning. We are in such a specially privileged, and therefore all the more responsible, position, that the voice of our Church ranges far and can exercise great influence. The life of our Dutch Reformed Church is interwoven with the life of our people in this time when our existence is threatened. And every true Afrikaner is deeply in sympathy with his people in this anxious time (and I associate myself with them as an Afrikaner who, just as in the past, today still wishes to serve his people with the same love and faithfulness).

Now I realise that there are many today who say: This is not the time to speak even if many things are not right, or not morally defensible: this is the time to keep silent and to stand by your people. Brethren, no matter how well-intentioned such a view may be, do we not as Christians understand that such an attitude is born of fear, and that fear is a sign of unbelief? Do we not believe that if we obey God in all things according to his Word, we can leave our future and that of our people with safety in his hands? Whose kingdom comes first: the Kingdom of God, or that of our people? Which is more important: that we stand together or that we all follow God? And what does it mean to follow God if it does not mean proclaiming the kingship of Jesus Christ over all peoples (and therefore also over our people) - and this applies also to our ecumenical and race relations? And when we as a Church fear or refuse to do this freely, then we let our people down - we betray our people!

If the DR Church will not take heed and carry out this obedience which God demands, then we shall suffer endless damage and sorrow. Not only will we lose or frustrate some of the best intellectual powers in our ministerial ranks, not only will we lose the confidence of thousands of members who seek more Scriptural illumination on all these burning questions of Church and state, of kingdom and people, of race and colour without finding it in their Church - even more: our 
Church is irrevocably estranging the affections of our "daughter" churches of Africa. If our Church continues with this conscious and fear-inspired process of isolation, with its tragic withdrawal from the Holy Catholic Church in South Africa and Africa, we shall, spiritually, wilt and die! O my Church, I call today with all the earnestness that is in me: awake before it is too late, stand up and stretch out the hand of Christian brotherhood to all who reach out to you in sincerity! There is still time, but time is becoming short, very short.

But also for us as ministers of the word, Acts 5:29 has meaning. Very many ministers are deeply concerned about the course of events in our Church. Many are concerned because it appears that the Church is not free to act solely on the authority of God's Word because other influences and powers are playing the dominant role. Many are convinced that great changes will have to take place in our ecclesiastical and race relations on many levels. But for various reasons they suppress these convictions:

the fear that if they speak, the Church will be harmed, the fear that our members are not yet ready to accept these truths, the possible repercussions in our congregations.

In such a situation we are all called to act with the utmost responsibility, but certainly not to remain silent. The proclamation of the truth of the Gospel cannot harm the Church of Jesus Christ! And if our members are not influenced by all sorts of other powers but are enlightened fully and fearlessly as to just what the Word of God requires of all people (white as well as non-white), then will the Spirit of God not lead them into all truth? Why then do we fear? Has the time not arrived for us to proclaim clearly and with joy: Thus saith the Lord?

Finally: this text has meaning for the other churches in South Africa and for the Christians in those churches (white as well as non-white). You who with us confess faith in Christ and his Word: Is your first obedience and your highest loyalty to Christ? Are you prepared to call on your people to seek this obedience and set it above all else? Even where it conflicts with their deepest human sentiments? Are you prepared to recognise injustice where injustice has occurred (also against the Afrikaner) to give love and sympathy where it is needed and to humble yourself so that Christ may be magnified?

To all Christians of all churches and peoples and languages and races who sincerely seek and pray for this highest obedience to God comes his glorious assurance even for the unsure future: if God is for us, who can be against us? 
Dr M Nash ${ }^{2}$

\section{Introduction}

Good morning and thank you for the opportunity to share with you in this reflection on the life of Beyers Naudé. When I see people like James Cochrane, John de Gruchy and others who have not only worked with Beyers but also reflected much more deeply and more academically than I have, I feel somewhat inadequate. However, I have known Oom Bey for rather a long time, having met him at the 1951 Winkelspruit constitutional conference at which the Christen Studente Vereniging (Student Christian Association) voted to split - into five racially based sections. (To my shame I voted for the new constitution, thinking only of the advantages for the English-Medium Work.)

\section{Beyers Naudé: A life of mystery and revelation}

For me the life of Christiaan Frederik Beyers Naudé has always had the character both of mystery and of revelation. Mystery in the sense that the trajectory of his life changed so radically at a stage when it was very difficult to do so. Revelation in that the change reflected the ongoing interplay between divine grace and human response. I sometimes think Martin Buber could have had Beyers in mind when he wrote: "All revelation is summons and sending. God remains present to you when you have been sent forth. He who goes on a mission has always God before him. The truer the fulfilment the stronger and more constant God's nearness".

I shall try to set out the life and times of Beyers against the background of three lines of influence and activity: South African history; the unprecedented growth of the ecumenical movement expressed at student level in the World Student Christian Federation (which in 1896 gave birth to the Christen Studente Vereniging (Students Christian Association) in Stellenbosch and at an older level in the Edinburgh 1910 International Missionary Conference and the host of organisations which followed it, leading to the World Council of Churches; and developments in the Dutch Reformed Churches.

1 Tribute to Beyers Naudé delivered at the celebration of his 89th birthday on 31 May 2004 at the Beyers Naudé Centre for Public Theology at the University of Stellenbosch.

2 Margaret Nash served on the CI National Council 1973-77. Her UCT doctoral thesis on "Ecumenical Movement in the 1960s" was published by Ravan Press in 1975. 


\section{Early influences}

\subsection{Childhood}

I as an English-speaking person have no real concept of the depth of bitterness in the Afrikaans community at the end of the South African War (1902). Beyers's father was one of the bittereinders (diehards). In later years he named his firstborn son after the famous Boer general who drowned crossing a river after the Rebellion in 1915, when the Afrikaners were split on the World War I German-British Allies conflict. Beyers was born into this identity, it was impressed upon him, he knew it and grew up with it.

However, there were other influences on the Afrikaans faith community. The great Protestant missionary revival of the 19th century gave rise to the Andrew Murray revivalist preaching and the practice of the Pinkstertyd Biduur (Pentecost prayer meetings). During his father's Pinkstertyd preaching in 1930 Beyers underwent a deep spiritual conversion which never left him.

Growing up in the pastorie (the minister's residence) he also experienced tensions. For example, when his father was called to Graaff-Reinet and there preached his first sermon in Afrikaans rather than the traditional Dutch, there was uproar and the congregation split.

\subsection{Student years}

Unsurprisingly, there was a strong independent streak in Beyers, manifest in his student years. He and his brother, Jozua (Joos), went to Stellenbosch University, very much at the insistence of their mother, Ada. There the two young men enjoyed a new range of opportunities. They joined the debating society, the hiking fraternity (Berg-en Toerklub) and the SCA. These enabled them to mix with young women more freely than in the past. They also contributed anonymously to Pro Libertate, an 'alternative' student paper competing with the more conventional student publication.

Through the hiking club Beyers really got to know Ilse Weder, daughter of Moravian missionaries in Genadendal, where he began to visit with her. Genadendal was a non-racial Christian community, predominantly so-called coloured. For Beyers this was a new experience because up to that time, in his own church and community circles, the separation had been almost complete. The black or coloured communities were objects of mission. They were not fellow-Christians in the sense of the body of Christ. The importance of Ilse in the life of Beyers cannot be over-emphasized.

Turning to South African history, during the 1930s there was a strong upsurge of Afrikaner nationalism, culminating in the centenary re-enactment of the Great Trek. At the time I was a pupil at a Roman Catholic convent school and still remember how even we were subjected to the black-and-white films of the 
struggles and achievements of the Trekkers. Beyers and Ilse actually attended the great Pretoria celebrations in December 1938. Who could have anticipated the future of those two young people?

During Beyers's time at the theological seminary there were contradictory influences. Some of the leading professors had attended the 1910 Edinburgh Missionary Conference and become involved in the International Missionary Council. But conservatism was a growing force. The heresy trial of Professor Johannes du Plessis, which began in 1928, effectively closed down debate, especially on biblical criticism and interpretation. Men like B B Keet, who was still at the seminary, felt they had to be very cautious. After four years Beyers was glad to leave what he described as an atmosphere of dull mediocrity. Later in life he acknowledged having a very shallow theological foundation. He graduated, married Ilse and they moved to an assistant pastorate in Wellington.

\section{Beyers Naudé's ministry in the DRC}

In Wellington Beyers discovered that the missionaries of the church - the sendelinge - were being given a relatively second-grade education at the Mission Institute in contrast to the academic curriculum of the kweekskool in Stellenbosch. This seemed like a sharp contradiction. In student Christian circles members of the Student Volunteer Missionary Movement were the crème de la crème, the missionary task of the Church - bringing civilization and Christianity to Africa - being regarded as of the utmost importance.

In the meantime the Second World War intensified the split in the Afrikaans community on the issue of support for the Allied war effort. Beyers's father was among those who in 1918 established an organization initially called Young South Africa, later Die Broederbond (The Brotherhood). It was to be a service body for the reconciliation of all the Afrikaners in a single brotherhood, one in which Afrikaners, amidst confusion and disunity, would be able to work together for the survival of the Afrikaner people and the promotion of Afrikaner interests. In 1920 the Broederbond, of which Bey's father had become president, decided to go secret. It gradually became the most powerful structure in the country, and to the extent that apartheid succeeded, it was the achievement of the Broederbond.

The Nationalists came to power in 1948 on a minority vote, the constituency system being loaded in favour of the rural areas. The country already had racial discrimination, formal and customary. The new government moved swiftly to systematise and entrench racial separation through the Population Registration Act, Group Areas Act and the Immorality Act. The Suppression of Communism Act was to penalise opposition. These four laws alone were enough to start changing, with painful effect, not only the social geography but also the human relations and sense of dignity of most people in this country. 
The African National Congress, established in 1912 in reaction to the British handover of South Africa to the white minority, and other "non-white" political organisations embarked on strong programmes of resistance. Notable were the Defiance of Unjust Laws Campaign (1952), the Freedom Charter Campaign (1955) and the Women's March to Pretoria (1956). In between this polarization of Afrikaner and Black South Africans were the supposedly more liberal white English-speaking people, most of them unwilling to sacrifice their privileges and restricting themselves to verbal criticism. By 1960 the country was ripe for disaster. It came in the form of the March 21 Sharpeville massacre in reaction to a nonviolent anti-pass law demonstration, followed by a state of emergency, bannings, detentions, etc.

From Wellington Beyers soon moved to Pretoria as a student chaplain and became involved in organising the KJV (Kerklike Jeug Vereniging). In 1953 he and Ds. W Strauss made a six-month study tour of youth ministries in Europe and North America at the invitation of the WCC Youth Department director, Dr Albert van den Heuvel. This was the first of many attempts by van den Heuvel to conscientize white DRC clergy. However, at the time, Beyers commented that his overseas experiences on the tour had not particularly influenced him.

From Pretoria Beyers moved to Potchefstroom, to his fifth congregation. Here some of the theological students whom he had met earlier during his student chaplaincy and who now were ministering in black, coloured and Indian "daughter" churches, were coming to him and saying: "Beyers, do you know what's happening to our people? Come and see!" At their insistence he began to visit them and found he could no longer ignore the unjust and destructive effects of apartheid.

However, he was also deeply embedded in structures of a church that was handin-glove with the apartheid government. His reaction was to say: "I've got to educate myself on the Bible, the church, the place of race in the Bible..." And so, right through to the end of 1961 there was no outward sign of dissent, opposition, resistance to apartheid on his part. I term this the Nicodemus stage of Beyers's movement towards challenging racial injustice. For years he concentrated on educating himself with the help of those colleagues and others. He took advantage of the meeting in Potchefstroom of the World Reformed Ecumenical Synod and studied with the Doppers, the Gereformeerde Kerk (Reformed Church). He was becoming theologically much better educated.

The 1960s became very important ecumenically. The December 1961 Third Assembly of the World Council of Churches in New Delhi was marked by three important developments: the International Missionary Council was to be integrated into the WCC and a large number of new churches were admitted, mostly from East Europe and the Third World (the former mission field), reducing the dominance of Western churches. 
The third development came through an unexpected theological input by Dr Joseph Sittler, a Lutheran theologian from Chicago. Speaking about the call to unity, he expounded the Colossians view of unity as cosmic, as God's will for the unity and harmony of the whole of creation, including but not restricted to church unity.

The WCC constituency wasn't ready for this new perspective. It caused confusion and controversy. They didn't know what to do with it, so they referred it to the Faith and Order Commission, due to meet 18 months later. When the Commission duly met in Montreal in 1963, it decided to set up a study commission headed by Dr Hendrikus Berkhof, a famous Reformed theologian from the Netherlands. Not having much of a budget, they circulated correspondence to 100 theologians throughout the world, asking them to reflect on and to respond to Sittler's paper. Remarkably, by the time Faith and Order met again at Bristol in 1967, there were no conflicts. It had become quite obvious that Sittler was right; that the essential context of church unity was the unity of the Whole.

This was to prove relevant to the South African situation in that during the 1960s socio-political and economic tensions and conflicts had intensified in many parts of the world - the Civil Rights movement and Anti-Vietnam War movement in the USA, the growing consciousness of the effects of decolonization, the youth and student rebellions in 1968 and 1969. The 1966 WCC Church and Society Conference in Geneva was a very turbulent affair and the South African churches and some other Western churches were saying that the World Council of Churches had been "hijacked" by the leftists, that it had been politicized and had lost its theological base. Yet quietly there in the Faith and Order Movement a theological base was being established that addressed the whole of life and not just the parts labelled 'religious'.

Returning to South Africa: when the Sharpeville crisis occurred, reactions varied. Some people and institutions were almost paralysed. Fortunately the WCC picked up the challenge and sent American Presbyterian theologian Dr Robert Bilheimer to consult individually with the WCC member churches, with a view to bringing them together in prayer, consultation and commitment to joint action. As a result of his dedicated work a consultation did take place at Cottesloe in December 1960 with WCC representatives as well.

Together they prayed about and reflected on the political crisis. The South African representatives came up eventually with a statement that was not that radical about how God moves people to unity - and committed themselves to move forward together. The apartheid government saw this as a threat and put heavy pressure on the DRC representatives to recant.

Beyers was the one member of the DRC who did not recant. He bought time through a process of meetings, consultations and organizing prayer and study 
groups which reached across racial and denominational boundaries in a way that had previously seemed unthinkable. They expressed and strengthened a growing breadth and depth of ecumenical awareness and commitment, and were supported by many overseas churches. The journal Pro Veritate was developed as a channel for theological reflection. Through these activities Beyers became a powerful leader of biblically-based opposition to apartheid. He was also involved in a number of law suits. One way or another, his position in the DRC was becoming untenable.

\section{The years at the Christian Institute}

In 1963, as first moderator of the newly founded Synod of the Dutch Reformed Church in the Southern Transvaal, Beyers was high up in the ecclesiastical hierarchy. Possibly the Broederbond had been instrumental in his being pushed up through the ranks until, metaphorically, he was standing on the roof of the temple, with Satan beside him, pointing to the power of DRC leadership and saying: "I'll give you all this IF..."

He had to choose between working with a small committed body of people comprising the Christian Institute, which would take action on issues of injustice based on true biblical principles, or a bright career in the church hierarchy. Beyers, with the full support of Ilse, courageously chose the Christian Institute. It must have been like walking into the desert that was desolate but full of demons. The story of the CI from 1963/1964 to 1977 is a complicated and bewildering tale. Interactions between Beyers and the Dutch Reformed Church leadership continued, Beyers' attitude to the Church being like that of Job towards God: "Though you slay me yet will I trust you". At the same time he was continually reaching out to the clergy and lay members of the Dutch Reformed daughter Churches, building links between them and overseas supporters - I recall an incident in 1971/72 which shed light on this process. The parish council of St Saviour's Church, Claremont, had invited Professor HW van der Merwe, Director of the UCT Centre for Inter-Group Studies and a deacon in the powerful Rondebosch DRC congregation, to discuss Christian responsibility in regard to the migrant labour system. When asked by one of our councillors whether Beyers Naudé had not lost influence when he resigned from office in the DRC, HW replied that in his opinion Beyers was the single most influential Dutch Reformed Church minister in the country!

In 1966 the Christian Institute and the South African Council of Churches jointly issued a Message to the People of South Africa. It was the South African equivalent of the 1934 Barmen Declaration of the German Confessing Church, setting out what true faith in God meant in that situation. The fierce ensuing debate led to SPROCAS I, the independent Study Project on Christianity in an Apartheid Society. SPROCAS established six commissions composed of 130 South African theologians, educators, health workers, sociologists and economists of all races. Their specialist 
study groups dealt with different aspects of society, analysing the changes needed in a post-apartheid era. In the process many ad hoc publications were issued and much educational work was done. This hugely demanding project extended over five years and also led to the establishment of Ravan Press managed by Peter Randall.

The SPROCAS I reports led to more controversy, this time about how to translate theory into action. SPROCAS II was comprised of two elements. One was the Black Community Programmes which built on the Black Consciousness Movement and facilitated grassroots work in literacy, health, job creation, etc. The CI, respecting the feelings of black leadership, played a background role of support in securing resources. The second element was a White Consciousness of Values Programme that attempted to help white South Africans to reflect on their lives and attitudes and to change direction. Unfortunately, the white programme petered out quite soon. It was followed by a Programme for Social Change, which suffered a similar fate in an increasingly repressive situation.

In the years 1972 to 1975 the so-called Schlebusch Commission of Inquiry investigated "certain organizations suspected of subverting the state". These, of course, included the CI. In the 1975 Final Report of the Schlebusch Commission the CI was declared an "affected organization", preventing it from receiving any foreign funding in the future. In anticipation of this development at least three ecumenical organizations had emerged: Diakonia in Durban, the Pietermaritzburg Action for Christian Social Awareness (PACSA) and the Theological Education and Action Movement (TEAM) in Cape Town. All three effectively became channels of foreign funding and support for the $\mathrm{CI}$ and similar work

The CI itself began to restructure, developing a constitution for a locally sustainable organization. Then came the June $16^{\text {th }}$ Soweto Uprising in 1976 and an unprecedented intensification of the anti-apartheid struggle followed. On October 19th 1977 the government announced comprehensive bannings: all major black organizations, certain black newspapers, some important black individuals and Beyers Naudé and the Christian Institute. This testified to the fact that he and the $\mathrm{CI}$ had indeed become an acknowledged part of the liberation movement.

These years of Beyers's life are best summarized by Charles Villa-Vicencio: "Beyers relentlessly sought to cross frontier after frontier. The Christian Institute, that initially bore the marks of his white reformed and scholarly theology, became increasingly open to the cross-currents of ecumenical thought and above all, black thinking and critique". He quotes Beyers as saying: "I discovered that one's quest for life and liberation is an enduring journey. There are repeated barriers to cross; and each time there are those who refuse to make the crossing right through. That is just the way it always is. All one can do is to take people as far as they can go. It is never easy to travel alone, but then there are always a few who are already on the road. It is merely a case of linking up, travelling on together." 
Humanly speaking, the banning was the end. However, as our Lord told his followers on the eve of his own crucifixion, "A grain of wheat remains a solitary grain unless it falls into the ground and dies; but if it dies, it bears a rich harvest" (John 12.24).

\section{The legacy of Beyers Naudé for today}

I must apologize for this very patchy presentation. It must be very frustrating for those of you who know the story backwards, and perhaps too patchy for those of you who are newcomers to the country or to the story. But I do want, in conclusion, to spend a few moments on the question: How best do we celebrate and honour this person as a latter-day prophet? - "we", in this case, referring to white participants here today. I shall not presume to give advice to fellow South Africans from the underside of apartheid. In trying to answer this let me use a couple of images.

The first is from the opening chapters of the Book of Ezekiel. In it we read about fantastic visions of the glory of the Lord with "a windstorm coming out of the north - and an immense cloud with flashing lightning and surrounded by brilliant light", etc. Then a voice tells the prophet that he is being sent on a very tough mission, and he is translated in the spirit to Babylon, sitting among the exiles beside the river Kebar outside the city. Elsewhere we read that they were very depressed, saying "How can we sing the Lord's song in a strange land?" since for them God was back in Jerusalem. In Ezekiel 2.15 we read that the prophet sat there with them seven days and seven nights, dumbfounded, overwhelmed. It was only then that the Word of the Lord came to him.

For me the combination provides a very powerful image, one that often came to mind when I was a liberal white activist during the apartheid era. It also makes me think of 1980, when Dr John Pobee of the WCC Theological Education Fund addressed an SACC conference on The Kingdom of God and Justice in a Sustainable Society. He ended his address with a short series of questions, one of them aimed specifically at white South African Christians. He spoke about the credibility gap between what we said and what we did, and appealed to us to address the crisis of confidence which that caused. The question he posed was: Where in this unjust context is the mark of the cross in your lives?

Today those of us who are white middle-class South Africans are still beneficiaries of the old, unjust and unsustainable apartheid society. In the new South Africa we have a human rights-based political dispensation, but we still have gross disparities between rich and poor. As a country we are part of a global system that is fundamentally unjust and morally indefensible.

I believe that in such a situation it is not enough for us just to study, write articles and books, not enough to be content with presenting verbal criticism of economic 
injustice. But what should we be doing? I cannot answer for others. I can only point at what happened to Beyers in the late 1950s, when his colleagues who were ministering among black South Africans went to him and said: "Come and see!"

Most of the black people here at this gathering have been exposed to poverty and township life, but that does not apply to those of us who grew up in privileged environments. On the whole most of us here in this conference are still living in comfortable middle-class settings; we have the professional, academic and ecclesiastical frameworks and responsibilities that give meaning to our lives. Suppose for the sake of argument that one set aside two or three hours a fortnight just to "go walkabout" in a township, an informal settlement or rural area amongst the farm workers - it better be an empty-handed walk. Leave your Rolex and your wallet behind.

The aim would not be to do something for others, but simply to expose oneself to another side of life. This exposure to the actual life of people who are in dire need and endure lives of degradation, exposure to their sense of helplessness and frustration is often needed in our own personal journeys. When Mother Theresa of Calcutta was teaching in a convent school for daughters of the wealthy, she used to go walkabout in the afternoons in the slums, where she saw a different side of India. Because she was a nun she could not do this alone and was accompanied by other nuns. Over many years she came to an understanding of what God was calling her and some of her companions to do.

To return to Ezekiel: I do not know whether subjecting oneself to the frustrations and needs of others would lead to seeing obvious remedies. It could be a slow and painful process. But I suspect that unless we do have this exposure to and involvement with the poor, there is likely to be a continuing problem of a credibility gap.

Finally, I want to refer to a book called Love Life - positive HIV stories, which James Cochrane's wife gave me two weeks ago. It is a book on life with HIV and Aids, composed by people living with Aids in Khayelitsha. In many ways it is a very positive book but also very sobering. The medical aspects involved are pretty horrific. But more than that, what is revealed through the individuals' stories is the state of social instability and even chaos in their lives, an amorphous, amoral pattern of people drifting through life without any anchors. It's almost as if HIVAids is a symptom of a societal pathology in our country that is light-years away from the ordered patterns of existence we middle-class people take for granted.

The problems in our present-day society are no less serious than those of the apartheid era, but whereas then we knew we occupied the high moral ground, nowadays the complexities are endless. We can pray for God's Kingdom to come on earth as in heaven, but that does not mean we know how best to live that prayer in South Africa today. In Beyers's life we have seen the sign of the cross. To honour 
him and our calling as Christians is to be confronted daily with the question: Where is the cross in your and my life? 


\section{THE FLAME OF FIRE AND SLEDGEHAMMER ${ }^{1}$}

Beyers Naudé

"Is not my word like fire," says the Lord, "and like a hammer which breaks the rock in pieces?" (Jeremiah 23:29, RSV)

No man would be able to exist under a word of the living God which does nothing more than continuously sear him as with fire and batter him as with a hammer. Is his Word not infinitely more than that? Is it not a healing salve for our wounds, water for thirsty lips, the word of peace for the troubled soul?

Certainly, that too is the Word of the Lord, and Jeremiah, the author of our text, does not deny it. If ever there was a man whose sensitive spirit and poetic soul yearned for the comfort and solace of the Word of God, Jeremiah was that man. Born the son of a priest, reared in the silent beauty of the countryside, this man of God was enlisted in the service of God while still very young, and his call to serve brought him in a peculiar way to Jerusalem. In conflict with his own temperament, and against his own wishes and desires, he was called upon by God to pronounce some of the most searing judgements against his own people that we have ever heard form the lips of a prophet. And this coincided with one of the greatest times of crisis in Israel's history - a time when her very existence as a people was threatened.

Time after time, Jeremiah confesses that God has laid a burden on his heart and mind through his Word, that, through this same Word, God grips and challenges him, that this Word has overwhelmed and crushed him, so that he cannot help crying:

O Lord, thou hast deceived me, and I was deceived; thou art stronger than I, and thou hast prevailed. I have become a laughingstock all the day; every one mocks me... If I say "I will not mention him, or speak any more in his name," there is in my heart as it were a burning fire shut up in my bones,

1 Farewell sermon delivered by Beyers Naudé at the Aasvoëlkop Congregation on Sunday, 3 November 1963. (Originally published in the collection of sermons by Beyers Naudé, My Decision, by the CISA. n.d.: 12-20) 
and I am weary with holding it in,

and I cannot.

(Jeremiah 20:7, 9 RSV)

This is what happens to a man when God's Word becomes a sledgehammer and a flame of fire!

But why is it that Jeremiah uses these figures of speech to describe the working of God's Word? Is it not precisely to portray the double action of the Word: that in one sense the Word apparently destroys like fire and shatters like a hammer blow but that in fact it renews and rebuilds? Think of your own life: have you not also found that the Word of God invades our private lives, addresses us, compels us to answer, in exactly those areas of our life which we so scrupulously try to hide and conceal? It is then that the Word comes to us in all its sharpness as a double-edged sword, piercing as far as the place where life and spirit divide, judging the thoughts and motives of the heart, and laying bare the deepest and most secret motives of our life!

The same is true if the life of our community: does not God use his Word to bring all the pleasant forms and customs of the Church, all our human systems and relationships, and all our social grandeur and traditions under the testing fire, under the sledgehammer of his judgement? Does not God, sometimes in a moment, break down the walls which we human beings have so nicely built up in our own wisdom over the years? Do we not often have to watch with shame as the fire of God consumes our handiwork of wood, hay and stubble and sends it up in smoke? God must break us before he can build.

But the opposite is also true: it is this selfsame fire which refines our dross, this sledgehammer which builds while it hits. Have you not experienced this in your own life: how God has created a new man in you, has given you a new heart, has given you new vision and power?

And also in the life of our community: is it not this the power and wonder of the Word, that it continually reconciles, recreates, renews? That God offers his Word to each community, each group, each nation and country, as the light of their life, the hope of their existence, the power for their struggle?

\section{Opposition by evasion}

But now comes this strange phenomenon: man, including Christian man, in theory accepts the Word (no, he does not reject it openly, that would look just too terrible) but in practice he renders the Word powerless in many ways:

1. By doing what the false prophets did in Jeremiah's own time - giving the people the hollow assurance that as long as the temple stood in their midst, no disaster or calamity would befall them. That was why they cried "Peace! 
Peace!" while Jeremiah warned that there is no true peace. Is it not true, beloved, that we too are often afraid to handle the Word as a fire and as a hammer, because it rouses men to opposition and revolt, because - possibly - it will burn our own hands and bruise our fingers? Therefore we too cry out in false security "Peace! Peace!" instead of sounding the trumpet-blast: "Awake, sleeper, rise form the dead, and Christ will shine upon you."

2. Or we allow the Word to be subjected to, to be enshrouded in, or to be replaced by the tradition by which its sharpness and cutting power is blunted, its absoluteness is rejected, its challenge lost. For how many have churchgoing, Bible study, the catechism, baptism, became dominant traditions? And are there not also national traditions which cannot stand up to the testing of the Word, but which we place alongside or above the Word? Does not the call for national unity which we have heard so often recently also run the danger of becoming a perilous and untrustworthy tradition if it is not constantly subjected to the truth of God's Word?

3. Or we acknowledge and accept the Word in theory for Sunday, but we disobey it by our reluctance to work it out in all its consequences from Monday to Saturday, in our thoughts and deeds in every aspect of our lives. And as soon as men of God boldly begin to do just that, the false cry goes up: the Church must confine itself to spiritual matters!

\section{Evasion leads to destruction}

What is the result when we thus dodge the Word? For quite some time one can successfully shy away from the appeal and the demand of the Word: apparently it does no damage, does not trouble the conscience, does not affect the church's service. But in fact there is a process of spiritual decline, of moral degeneration, of the disintegration of the Church, which sooner or later results in complete collapse. It is always so: no man, no community can withdraw any part of life from being subject to the Word without eventually finding the whole of life ruined thereby.

Over against that there is the sure and glorious knowledge that when we bow in obedience to God's Word, where we let ourselves be subject to it, where we set and seek Christ and his kingdom above all, then the Word becomes in the fullest sense Word of Redemption, Word of Renewal!

\section{The practical consequences}

What has all this to do with the situation in which we find ourselves today? If I am to answer that in the light of our text, then I must say: God is busy with his Church in South Africa as never before. One indication of this is the number of news articles on church affairs that appear almost daily in the press. This is true, not only of the Afrikaans churches, it is true also of the Church of Christ among the English- 
speaking people, it is true of white and non-white. Some of us do not like this - we say that it provokes unrest and controversy. Some people blame it on the statements and actions of certain churches or church leaders. It is certainly true that by the actions of men a situation is created in which Christendom and the Church are hard pressed by the world. But this is not the whole truth - for behind the decisions of churches and the resolutions of ministers stands God. It is he who brings matters to a head, it is he who brings his Church, his servants, his children to total obedience to his Word. It is he who comes to us with a Word that flames like fire, which shatters like a hammer blow to bring us back to the fundamentals of our faith, to the source of all light and life - his Word. And when I say "his Word", then I mean primarily his living Word Jesus Christ.

That is what God is doing. He is doing it because he loves his Church, loves it too much to let it keep silence because it is afraid, too much to let it witness only through pious worship, too much to leave it quarrelling in discord, too much to leave it frozen in formality.

And for that we must be thankful; we must not be angry or rebellious against God. Rather, we must see all this as the hand of God busy with the renewal of his Church. And we must see that he calls each one in his own individual way, calls him, sends him, places him as God sees best - sometimes along ways that we do not know and cannot understand. God meets peculiar times with strange deeds. One cannot help noticing - for it is conspicuous - that there is hardly a single aspect of life with which the Church today is not concerned: Sunday observance, marriage and family life, labour and technology, disease, prayer and healing, race relations, the threat of the atomic bomb, the vocation of the Church with regard to the state, the whole question of moral values - everywhere God is involving his Church in the struggle. Precisely for that reason, it is of the greatest importance that the Church of Christ should see just where God is busy and what he expects from every professing Christian: to take the Word seriously again, to wrestle with the Word so that once more it becomes the infallible rule for all our thinking and living, for our every being! So that God's Word again becomes predominant - and everything else subject, that God's Word may again take its free course, and that we may allow ourselves to be carried by that Word.

Where that happens, God's Word will lead us to God's Spirit, God's Spirit will urge us to prayer, prayer will lead us into fellowship, and fellowship will express itself in witness. Then the Church will again become the bearer of the Word which moves out into the world. Flame of fire and hammer blow!

If, however, we do not let God's Word be for us the renewing fire, then other fires will consume us; if we do not let God's Word be for us the hammer that breaks the rock, then the other hammers will destroy us. Hear this, O people of God! 
The servant in your midst

With this message this morning I bring to an end my ministry to you - so different from what any of us ever dreamed or expected. What lies ahead, no one knows but that is not really the important thing. What is important is that I have always stood in your midst as servant of the Word to bring you the message of God. And even if you forget everything else, if you remember only that for the first four years of the life of this congregation, God sent you somebody who in the midst of many human failings continually tried to summon you and bind you to obedience to God's Word, then my ministry here has not been in vain.

Also in the new work to which God calls me, I would do no more and no less than to summon Christians of different churches, and, in God's name, to challenge them to take his Word with all seriousness, to challenge them to think through and discuss, with honest and whole-hearted commitment, the burning questions with which life faces us, the problems of our time - all this, resolutely, in the light given by the Word.

What you yourselves may think of the step I am taking is not of decisive importance. What is of the utmost importance is that you should realise that God is summoning you through recent events. Let Christ take hold of you, Christ the living Word, let your thoughts and decisions be determined above all by him, the Word: let the future of your church, your people and your country be decided by him, the only living Word.

And if you are uncertain, if you have doubts, do not turn away. Wrestle with him, the living Word, just as Jacob wrestled with God and demanded "I shall not let you go until you bless me." Whoever does that will discover what every man and every community must discover: the answer to our question, the light of our life, the hope for our future, lies in total obedience to him who is the living Word - and to him alone. 


\section{BEYERS NAUDé: UNLIKELY CHAMPION OF JUSTICE}

Archbishop D M Tutu²

\section{The divine sense of humour}

I have often been amazed, perhaps tickled, by examples of what I can only describe as the divine sense of humour. Who would have picked as a primary spokesperson for the deity someone like Moses who had a speech impediment? We would have expected God to choose someone who was as golden tongued as John Chrysostom, but no, God chooses a stammerer. You recall that when God encountered Moses in the wilderness at the burning bush, God suggested that Moses should return to Egypt to confront Pharaoh. "God, you can't be serious - you know why I left Egypt? No, no - in any case", continued Moses, telling the omniscient One who knew and knows everything, "God, I stammer!" It didn't get him off the hook.

God was up to God's old ways even in the matter of the Incarnation. Now we would have expected that the Son of God, King of Kings would have a dazzling pedigree with parents who belonged only in an exclusive Who's Who list. But no, God chooses a village carpenter and a teenage village girl to be the parents of God's Son. Well, where are royalty born? - in sumptuous royal palaces of course. Well, this Son of God the only begotten had parents who did not even have enough clout to procure a room in the overcrowded village inn. They say Joseph approached the innkeeper and said, "Please, help me - my wife is about to give birth!" And the innkeeper retorted, "Well, that's not my fault!" And Joseph replied, "It's not mine either."

And so the Son of God was born not in a royal palace but in a stable with the animals nuzzling the Babe in the manger.

\section{The divine preferences}

God is forever seemingly turning upside down our expectations about rank and position. Just look at the one we are honouring tonight by naming this Centre after him. C F Beyers Naudé, affectionately referred to by many, many as Oom Bey.

You know, I was appointed General Secretary of the South African Council of Churches in 1978 in very large part because the officers of that splendid body believed it was time that it should have a black General Secretary, since its constituency was so overwhelmingly black in its member churches. Well, when I left in 1985 to become Bishop of Johannesburg, do you know those very same

1 Address delivered at the official opening of the Beyers Naude Centre for Public Theology, Stellenbosch, 21 November 2002. Copyright Archbishop D M Tutu. Used by permission.

2 Archbishop Desmond Tutu is Archbishop Emeritus of Cape Town of the CPSA. 
people who had been so committed to black leadership, without batting an eyelid and with no one feeling that they had thoroughly contradicted themselves, appointed as my successor a white man and not just any white but an Afrikaner to boot. And there was no outcry; in fact the appointment was widely acclaimed. That Afrikaner was Beyers Naudé, someone named after a general in the Anglo-Boer war by a patriotic father. This father, himself a dominee, had been a founding member of the Afrikaner Broederbond, which was to wield such very considerable power and influence in the affairs of the Afrikaner community. You could not amount to anything in any sphere in public life, in business, in education, in politics, if you were not a member of, or approved by, the Broederbond.

Beyers had the most impeccable pedigree in the Afrikaner elite establishment. He himself was to become the youngest member of this clandestine body and everyone who was anyone predicted that he was destined for great things either in the Church or in politics. They said it was just a matter of time before he would hold the highest position in Church or State as he chose. And it seemed as if these expectations, indeed predictions, were already being fulfilled since he quickly became first the acting-Moderator and then Moderator of the N.G.K Synod in the then Southern Transvaal after his training here at the University of Stellenbosch and after church appointments as a dominee in places such as Wellington, Pretoria East and Potchefstroom.

How could such an unlikely candidate, such a quintessential NG dominee, who saw nothing wrong with apartheid and who opposed supporting Britain against Hitler in World War II, have become the man who could be appointed General Secretary of the South African Council of Churches without anyone raising an eyebrow or being outraged? What had happened to effect what seemed such an extraordinary metamorphosis? For as a supporter of apartheid, which had been declared a heresy by the SACC following the epoch-making declaration by the WARC in 1982, he would have been total anathema, someone that that organization would not have wished to touch with the proverbial barge pole, especially as the Church to which he belonged then had left the SACC two decades previously. What had happened?

\section{The Damascus experience}

I don't need to rehearse the history of our land with which we are all familiar. Suffice it to say that things had reached such a state that the political organizations of the disenfranchised majority of our land, the ANC and PAC, called for demonstrations against the iniquitous and much hated pass laws, which restricted the movement of blacks so severely in the land of their birth. And so it happened that on March 21st, 1960 that the PAC organized a demonstration in Sharpeville. A huge crowd marched on the police station to surrender their passes. Disaster struck when panic-stricken police opened fire without apparently receiving orders to do so and sixty-nine persons were killed, most of them shot in the back as they 
were trying to run away, and several others were wounded. The world was appalled by this example of the inherent brutality of a vicious system. The economy was shaken to its foundations. Dr Verwoerd, sometime professor here and who had taught here, and then Prime Minister, the brilliant architect of apartheid, responded with the intransigence that was to characterize all apartheid governments until the courageous initiatives that President F W de Klerk announced on February $2^{\text {nd }}, 1990$. Dr Verwoerd imposed a state of emergency and banned the ANC, PAC and SACP, which now went underground and adopted the armed liberation struggle, since they could no longer operate openly and nonviolently.

The World Council of Churches convened a meeting, the famous Cottesloe Consultation, of its South African member churches, which included the NGK and NHK. This historic meeting produced a resolution that condemned apartheid as unscriptural. Most of the delegations concurred, including the NGK, although the NHK rejected it. The Prime Minister fumed and caused the NGK to repudiate the Cottesloe resolution and it walked out of the WCC.

Perhaps that was Beyers Naudé's Damascus road experience. He rejected his Church's decision. He was already married to the Moravian, Ilse, with whom he used to visit Genadendal, where he was exposed to inter-racial social intercourse and mixed church services, which were in stark contrast to the rigidly segregated worship of his own Church. These experiences may have begun to sow doubts in this Saul, and Cottesloe served as the catalyst that helped to transform him into a new Paul. On his own submission, it actually all started while he was a student here. He had been appalled by the heresy trial of Professor Johannes du Plessis, who was vindicated by the Supreme Court but expelled from the Seminary which, however, paid his salary until his death. Beyers was greatly influenced by his ethics professor, B B Keet, who in 1961 wrote a disturbing book entitled, The Bell has Already Tolled. Later he was influenced by Professor Ben Marais, who in 1952 wrote Die kleur krisis en die Weste, which questioned the biblical and theological justification for apartheid. His last sermon to his NGK Aasvoëlkop congregation was on the imperative to obey God rather than man and he was from then on out in the cold in a sense ${ }^{3}$. He had founded a theological journal, Pro Veritate, of which he was editor. Two years after Sharpeville he was surprisingly elected Moderator of his Synod, which asked him to resign this editorship. He refused. It was a costly decision that he had made and the price he was to pay consisted of his being ostracized and vilified by his own Afrikaner community which regarded him as a traitor, a verraaier, a turncoat who had betrayed the Volk. Social ostracism is harsh and painful, particularly for Afrikaners who, like Africans, are a very communal sort of people deriving nurture from the intimacies of corporate existence. To be banished from the community was a living death, an experienced hell.

3 See pages 25-29 of this publication - ed. 


\section{The integrity of the gospel}

Many in the black community were seeking someone who might restore some credibility to the gospel of Jesus Christ and to faith in a God who seemed so unmoved by the plight of God's creatures. Blacks did not doubt the existence of God, nor that God was omnipotent, nor even that God is good. The theodicy that would make sense for them was one that answered the question, "God, for goodness' sake, on whose side are you? Why have we been identified as the objects of so much suffering and that at the hands not of pagans but of those who called themselves Christians, who go dutifully to church every Sunday and also purportedly read the same Bible and worship the same God?"

In God's inscrutable ways, it was to be this Saul with such unprepossessing antecedents who would become the Paul to recover that integrity for the gospel of Jesus Christ. Beyers with some close associates founded the Institute in 1963 which helped people to realize that the living God was a God who was notoriously biased, always choosing to side with the voiceless, those without clout, the hungry and homeless. This was the same liberator God of the Exodus who had led a rabble of slaves out of bondage to freedom, who was engaged in the fray to set free all God's children from the bondage of injustice and oppression. This God cared that people lived in squalor, in deprivation, that their dignity was daily trodden callously under foot and who rejected "pie in the sky when you die" religion as an abomination. The Christian Institute helped to rehabilitate Christianity in the eyes of the oppressed.

It supported the Black Consciousness Movement of a Steve Biko and the Black Theology of such as Itumeleng Mosala and others. It pioneered theological training for the pastors of the so-called African Independent Churches and proved a thorn in the flesh of the apartheid regime and a radical partner to the churches, always asking awkward questions and refusing to make peace with injustice, oppression and suffering.

It did not take long for the government to regard the Institute as anathema and its director, Beyers Naudé, as more than just an irritant. For the multitude of blacks who had been running the gauntlet of a vicious system the gospel had found the champion they had been longing for. Here was someone who proclaimed a God who did not give useful advice from some impregnable mountain fastness, but one who was indeed Immanuel, immersed here with them in the muck of their misery, who entered the fiery furnace of their anguish. It was not long before Beyers fell foul of the repressive regime's draconian laws.

After the death of Steve Biko in detention in 1977, the government resorted to its usual strong-arm tactics - it banned several newspapers, detained several persons who were seen as agitators and the counterparts of the external terrorists, the ANC and the PAC. The Christian Institute was declared an affected organization, 
meaning it could not receive funds from abroad, which effectively hobbled it, and Beyers had a five-year banning order slapped on him. He would now be a prisoner at his own expense, condemned to a twilight existence when he could not leave his home all through a whole weekend, confined to a specific magisterial area. $\mathrm{He}$ could not attend a funeral or a wedding without special permission from the authorities and he could meet with only one person at a time, otherwise it would be a gathering which he was prohibited from attending.

Ironically, the world flocked to Greenside in Johannesburg to see someone who had become a legend in his lifetime. And even more ironically, he was banned under the provisions of the Suppression of Communism Act. Not too surprising in a land that could provide us with the appellation "Foreign Natives", meaning blacks from other countries. God had found the champion God had been looking for, who proved his mettle as others had done before him by the extent of his suffering. He had already suffered through being expelled from his Afrikaner community, but it was compounded now by this enforced isolation. He was bearing witness to the imperatives of the gospel in the time-honoured way of suffering. He was not killed but he underwent a white martyrdom - a true martyr/witness/martus and that gained him considerable support in the black community. There could now be no doubt whatsoever about his sincerity - it was being attested in this painful and public manner. He was speaking about a God who cared and yet the oppressed remained in their condition for a few more decades.

Was he preaching a delusion? Did God really care? Theology was not just a neat, tidy thing for books and lectures; it was engaged; it was authenticated by striving to answer questions of life and death. It was particular and contextual. Was God there at all? Was it not just a matter of words?

\section{Vindication}

Beyers remained under banning orders for seven years (a biblical number?). To the annoyance of the apartheid government each act of vilification, of harassment, each denigration from them and their sycophantic cohorts perversely enhanced his reputation and credibility here among the oppressed, and abroad. They seemed to say that if he was being attacked by this illegitimate and repressive government, then he must be a splendid person. The government should have tried praising him even if it stuck in their gullet, but then they would have lost support in their constituency.

And then 1990 happened and South Africa was never to be the same again. What an extraordinary vindication awaited Beyers. He had already experienced some measure of reward for all his suffering. At the highly charged funeral of the Cradock Four who had been brutally killed by the security establishment, some of 
the huge crowd carried their idol Allan Boesak on their shoulders, and there was a white man who was also acclaimed in this fashion, and that was Oom Bey.

That was an enormous feather in his cap. The people proclaimed that his skin colour was a total irrelevance. The most important thing about him was that he had courageously opposed apartheid and had paid a heavy price for that opposition and the people were now rewarding him. When the ANC and the National Party began negotiations that would lead to the birth of democracy in South Africa, wonder of wonders, Beyers was included as a member of the ANC delegation. That was one of the highest compliments that the liberation movement could pay a non-member, inclusion in these crucial discussions, inclusion of one who had had such antecedents - speak of a wheel coming full circle - he was moving in very exalted political circles, but not as had been expected when people made their predictions about what lay ahead for him.

And then his Church, which had treated him as a pariah, invited him and Ilse to a session of their General Synod and there made a handsome public apology for the manner it had treated him and others of its members who had been prophets.

I was with Beyers in the vestry of the NGK Pretoria University Church before the start of a memorial service for Professor Johann Heyns. The assembled clergy asked Oom Bey to lead them in prayer. I asked him how it felt to be welcomed back and he said with tear-filled eyes how thankful he was to God that it should have happened while he and Ilse were alive.

The divine bounty has been limitless in the case of Oom Bey - God has really gone to town in lavishing on this servant of God honours and awards as if God were rehabilitating Job. When Madiba was celebrating his $80^{\text {th }}$ birthday and his marriage to Graça, there was an opulent celebration at Gallagher Estate. I was sitting next to Oom Bey at the head table and this Afrikaner renegade was surrounded by a constellation of some of the brightest luminaries of the Struggle, the Walter Sisulus, etc., and he and I contemplated yet another example of the exquisite divine sense of humour. But I think the accolade that really takes the cake was when the City of Johannesburg honoured him with its Freedom and then lavishly decided to name a major highway in his honour. I suspect that they were rolling in the aisles in heaven when D F Malan Drive became Beyers Naudé Drive. I suspect that Dr Malan in heaven joined in the mirth. They named the City Hall Gardens the Beyers Naudé Gardens as well.

For him one of the greatest moments was when his alma mater at last acknowledged that it had produced a great, an outstanding, man in Beyers when it awarded him that honorary degree and now this Theological Centre. He told me when I saw him last a fortnight or so ago, "I told Ilse that she should reprimand me if she should detect arrogance because of all these honours." 
What a spectacular vindication for Oom Bey but, in a very real sense, what a spectacular vindication for God. God has been vindicated in the vindication of God's servant that indeed lies can never prevail for ever over truth, injustice and oppression can never have the last word, that this is indeed a moral universe, that goodness is stronger than evil, that light is stronger than darkness, that life is stronger than death. Victory is ours through Him who loves us.

Thank you for honouring a great man, a dedicated and faithful servant of God. May your work here be richly blessed and done to the honour and glory of God and in service of all God's children and for the expansion of God's Kingdom of truth, equity, justice and compassion. 


\section{FROM THE ARCHIVES \\ THE AFRIKANER AND RACE RELATIONS ${ }^{1}$}

Beyers Naudé

\section{The historic attitudes of the Afrikaner}

I will try to express these attitudes as objectively and truthfully as possible by mentioning outstanding characteristics of the Afrikaner as seen in his history:

1. A general attitude of seeing himself and his people as a nation apart from others - separate first of all from the other white cultural groups (especially the English-speaking South Africans of British decent), but also from the non-white national groups in our country. Despite his famed hospitality and sincere friendliness towards strangers, a certain aloofness and mental reserve appears; a curtain of non-commitment, or fear of involvement comes down the moment the Afrikaner feels that a situation arises which could threaten his identity, his nationhood, his cherished spiritual and cultural heritage. This is especially discernible when he becomes involved in situations where race and colour become factors.

2. A deep sense of mission as a "Christian nation" towards the non-Christian people around him (as expressed by extensive missionary efforts for more than a hundred years and the ever-growing financial support being given to all such efforts). But because such efforts are being conducted towards and draw in people of another race and colour, the accepted premise is that the fruit of such efforts should lead to separate churches for separate racial groups where each can worship God and express his understanding of the Christian faith in his own "indigenous" way amongst his own people. Two elements of human conduct, therefore, hold sway here: association as well as separation - with all the tensions and incongruities they create.

3. A third attitude to be found is the general view held by the majority of our Afrikaner people up till a short while ago of the basic inferiority of the nonwhite and the necessity that the Afrikaner (and for that matter the white man) should see himself in and accept his role of guardian over millions of people who are regarded as "children" and who for many years to come (some even talk of centuries) will be no more than people of inferior origin or background struggling to achieve some sort of maturity and responsibility - which can only

1 Excerpts from an address given in Johannesburg in December 1967 in which Beyers Naudé gives his own impressions of the characteristics of the Afrikaner on the issue of race relations from a historic and, at the time, current perspective. The address was originally published by the SA Institute of Race Relations as No. 9 in the series Topical Talks. n.d.: 1-9. (Copyright: SAIRR. Published with permission.) 
be gained with the assistance and leadership of the white man. In recent years this attitude has, for many, undergone a significant change. It is conceded that the theory of basic inferiority may not be capable of proof, but that the basic differences between the white and non-white races are so great and so fundamental that the only realistic way to deal with these is to keep the races as far as apart as possible.

4. Against this, there is the deep sense of justice which the Afrikaner has developed in accordance with his understanding of the Christian faith and what it demands of him in terms of just and humane dealings with those who, although they are regarded as basically or historically inferior, yet are also part of God's creation. Out of this understanding has grown, on the one hand, the attitude of those who felt themselves justified in "keeping the Kaffir in his place", but also those who (especially during the last quarter of a century) pointed out that justice demanded an attitude of equal rights and opportunities so that each racial and national group could develop to the fullest of its latent capacities - and that this could only be achieved through a full and total territorial separation of these widely divergent cultural and racial groups.

5. With regard to the relations between Christians of different races belonging to the same church, it is interesting to note that in the first hundred years of the history of the Dutch Reformed Church there was no separation on the basis of colour within the life of the Church in the Cape Province. All catechumens were instructed in the local congregation (sometimes in separate classes) and were admitted as members to the same congregation where the sacraments were administered to all in the same service, regardless of race or colour. Admittedly these were Coloureds and not Africans, but it was only after 1857 that the Cape Synod, after a long controversy and serious debate, decided that as a result of the "weakness of some" separate services would be organized and allowed for White and Coloured. This concession to weakness led first of all to the practice of separate services with separate sacraments and eventually was elevated to a principle of separate churches for separate ethnic groups, which became the "newer tradition" structure of the N.G. Kerk, where today we have four separate autonomous churches - one each for the Whites, the Coloureds, the Africans and the Indians - and linked together in an advisory Federal Council of Dutch Reformed Churches meeting once a year for a day or two. And this pattern of separation in the church in turn stimulated and so strongly influenced the thinking of the Afrikaner people that from this eventually emerged the political policy of separate development. Thus does false theology always create ideology.

6. Another attitude of the Afrikaner which has been and still is very prevalent is his fear of being overpowered, swamped or submerged by a hostile world. This holds true of his general attitude towards non-Afrikaners on the White side as 
expressed in years gone by in his fear of everything British, together with his fear of the "black masses" surrounding him with their preponderance of numbers, their more rapid growth in population, his vulnerability on account of their economic indispensability, their lower cultural, economic and religious standards and their increasing political demands resulting from their national awakening. This creates an attitude of insecurity, a kind of schizophrenic conduct where both sympathy and fear determine his attitude.

\section{Factors and forces which created and contributed to these attitudes}

It gives no satisfaction, however, to give a description of attitudes without also analysing the factors or forces in the life of a community which created or contributed to such attitudes. I will try to point out and explain the main reasons which have influenced the Afrikaner. Then I will consider some current trends and attitudes.

1. The first - and to my mind the strongest - factor in moulding the attitude of the Afrikaner has been his explicable but nevertheless unacceptable identification of his people as "a chosen people" with Israel, the chosen people of God of the Old Testament. In this respect the Afrikaner is not unique. Many other nations have, at some stage of their history done the same (e.g. the British, the Americans, the Germans). Joseph Chamberlain, for example, declared once: "The Anglo-Saxon race is infallibly destined to be the predominant force in the history and civilization of the world", while an American, Herman Melville, wrote: "We Americans are peculiar, chosen people, the Israel of our times; we bear the ark of the world."

This view of the Afrikaner people as a chosen nation called to a special Godgiven mission and manifest destiny as ordained by God was born out of a totally wrong interpretation of the Old Testament which led to a distortion of God's purpose. Afrikaners saw themselves as a chosen people, planted by God in the southernmost part of a vast continent, for the special purpose of being the torchbearers of the Gospel to the millions of heathens in dark Africa. What was first seen as an analogy eventually became a divinely ordained command and was proclaimed as such in numerous sermons of clergy, speeches of national and political leaders, and repeated and re-echoed in interminable letters to the press from the days of the Great Trek up to this day. In this conviction the Afrikaner was further strengthened by his strong Calvinistic outlook, his longing to find the direction for his whole life in Scripture, his consciousness that, just as Israel was surrounded by heathen tribes, so was he; that, just as Israel had to trek through the wilderness and face the hazards of the unknown, so it was with him and his people. The comparisons between the vicissitudes of the chosen people, Israel, and those of his own nation were so striking and so manifold that he fell prey to the natural temptation of a false identification of 
himself and his people with that of Israel. And in this the main blame rests on the Church and the clergy for their lack of sound theological insights and for their misleading Biblical interpretation. This misleading interpretation is also to be found in the distorted exposition of passages, like the curse of Ham (Gen. 9:10), the Tower of Babel (Gen. 11:1-9), the use of the word "bastard" (Deut. 23:2), God's purpose with the creation of man and the birth of nations (Acts 17:26) and the ignorance with regard to the true meaning of the Incarnation and the nature of the church.

2. Another factor which moulded the Afrikaner's view on race was the fact that the difference between Christian and heathen, between civilised and uncivilised, was determined and made discernible on the basis of colour. Add to that the fact of the Afrikaners' sense of mission as the bearer of the Christian faith to the unevangelised millions (all dark-skinned people) and the fact that, as the pioneers of a new country, their association with the non-whites was nearly always in the form of clash, strife or warfare in which they eventually always came out victorious - then one can understand how in the course of time contact with the non-white peoples always tended to leave the conscious or unconscious impression of superiority combined with fear - neither of which attitudes are conducive to the building of harmonious human relations. It is this fear of being overwhelmed, deeply instilled into the mind and heart of the Afrikaner, which has unconsciously moulded so much of his thinking and his emotional reaction to the non-white (especially the African).

3. A third factor which played a decisive role in determining the Afrikaner's attitude toward race was the ever recurring clash between Briton and Boer and his conviction (right or wrong) that the British race policy was much too liberal, unrealistic and fallacious and even dangerous. Time and again this clash occurred and unfortunately nearly always coincided with a situation where the Afrikaner's security was jeopardised, his rights were being threatened and the denial of what he regarded as his legitimate claims went hand in hand with the granting of increased rights and privileges to the "foreigner" or the non-whites. (As examples I would mention the liberation of slaves, the discovery of gold, the first and second Anglo-Boer Wars.) Thus British Rule became to be associated in the minds of the Afrikaner with a serious threat to his existence - a threat coming both from overseas and from his black neighbour's presence at his doorstep.

4. A fourth factor which deeply influenced the Afrikaner's attitude to race were the liberal attitudes and actions of overseas missionaries who came to South Africa. The fact that men like Philips, Van der Kemp and Read saw nothing wrong in social intercourse with non-whites on a basis of equality and that one of them eventually expressed this concretely in marrying a Coloured woman, brought to the surface all the abhorrence deep in the hearts of the rank-and-file 
Afrikaner of the dangers of miscegenation and the "subtle forces" undermining his traditional outlook on life. Here again we are faced with an inadequate and a distorted understanding of Scripture, on the basis of which any marriage between white and non-white was not only regarded as taboo but as sin. Thus a combination of British domination and liberal overseas missionary conduct created the deep-rooted fear and distrust of overseas agencies of the Englishspeaking churches and missionary societies, and of the ecumenical movement as symbolised by the Christian Council of South Africa and the World Council of Churches (not to mention the Vatican Ecumenical Council). It is against this background that the deeply regrettable reactions against the Cottesloe Consultation of December 1960 must be seen, which led to the withdrawal of the Dutch Reformed Churches from the World Council of Churches and to their present fear of becoming involved in any ecumenical activity.

5. Another factor which contributed to the present outlook of the Afrikaner was his historic isolation as a small, relatively poor and relatively uneducated rural community until the 1940s. While most of the Western nations were experiencing the changes inherent in situations of increased communication, of rapid social and economic change, causing violent spiritual and intellectual upheaval, the Afrikaner community, through its secluded and often selfimposed isolation, was largely unaware of all these forces which were changing the outlook and relations of millions of people, including the relations between white and non-white. New theological trends, new patterns of human behaviour, new standards of judgement, a new appraisal of the worth of the human being regardless of the colour of his skin, new challenges of communist enticement to the world's non-white population-groups - all these developments appeared on his horizon at a fairly late stage and with an impact which immediately called forth the reaction of shock and fear: a buttressing of all the conservative values, which make any meaningful changes well-nigh impossible.

6. The last factor I would like to mention in explaining the Afrikaner's traditional attitude to race is fear. I have already touched upon the Afrikaner's fear of the so-called "foreigner", whether he be British, Continental or Asian. I also pointed out how his minority position in numbers, in wealth, in education and international standing created a fear of losing his identity, his nationhood, his position vis-à-vis the growing number of non-whites. For the ordinary Afrikaner his traditional enemy always had a black face or included one - and it is this fear which determined so much of his attitude and policy towards his non-white neighbour in this country (despite his acknowledgment that the nonwhite need not be feared if the whites treat him in a just and equitable way). 


\section{Current trends and attitudes: Signs of change?}

Having now tried to indicate the major factors and forces over a period of 300 years that have formed the Afrikaner's attitudes towards race, it now becomes necessary to enquire which of these need to be changed and whether there are new forces at work effecting such change.

1. Scripture and Race: Although the traditional concepts regarding race may still be found amongst some of the laity in our Afrikaans churches and a very small minority of clergy who still attempt to justify apartheid on Biblical grounds, we may state without fear of contradiction that since 1950 a very significant change has come about in the theological approach on race of two of the three Afrikaans churches, namely the N.G. Kerk and the Gereformeerde Kerk. No theologian of any significance would any longer try to defend apartheid or separate development on Biblical grounds and, although there is presently an unhealthy silence in the ranks of those theologians who have rejected the traditional historic concepts, yet we know that such traditional concepts as the Afrikaner people being in a special sense "an elected people", of the curse of Ham as referring to non-whites, of the divine creation and separation of nations, have been rejected for good. It will still take a long time before this understanding penetrates the rank and file of the Church, especially because very little instruction or education on the controversial issues of race relations in the light of Scripture is currently being given. Because of serious difficulties which sometimes arise where such issues are dealt with, many clergy tend to avoid touching upon them in preaching and teaching - but despite this there is a new understanding slowly growing amongst the laity of the true nature and implications of the Biblical demands on these issues.

2. The Ecumenical Movement: The withdrawal of the major Dutch Reformed Churches from the Christian Council of South Africa as well as from the World Council of Churches has had a very disruptive effect on the whole ecumenical movement as well as on the Afrikaner people with regard to their relations with the English-speaking population, and it will take a long time before this breach is healed. It has once again focussed attention on the basic difference in approach to race relations between English- and Afrikaans-speaking church communities, but it has also resulted in a small number of Afrikaans-speaking clergy taking a definite stand on principle on these issues different from the traditional viewpoints held by the average Afrikaans clergy and the majority of its laity. It has also resulted in a renewal of interest and involvement in the race issue on the part of the twenty-seven churches and missionary societies belonging to the Christian Council, and thus the signs are there of a new stirring of mind and conscience which must affect the whole racial situation in South Africa. 
At the same time it must be stated that there is today very little difference between the attitudes on race of the English- and the Afrikaans-speaking laity. More and more English-speaking whites adopt the same attitudes as the Afrikaner, use the same unchristian arguments to justify their prejudice, privileged position or their fear - and where they do not agree in principle, they support outlooks on the basis of expedience. In this respect the ecumenical movement faces a serious challenge because of the lack of ecumenical consciousness amongst the majority of our laity. If the English-speaking Christians are not prepared to put their own house in order, they have no right to complain about the unchristian attitudes with regard to race found amongst the Afrikaners.

3. Secular forces creating change: The continued urbanisation of the Afrikaner, the process of secularisation creating a new generation with very loose ties to the traditional church, the inexorable process of economic integration of the nonwhite in our society as well as the stirrings in the cultural life of the Afrikaner (the phenomenon of the "Sestigers") and the political tensions of the struggle between "verlig" and "verkramp" - all these are factors denoting changes which must in the long run influence the whole outlook of the Afrikaner people towards his fellow-men of other cultures and colours. It is difficult to predict the eventual outcome, but it is clear that a new outlook is slowly emerging where a proportionately small but growing number of Afrikaners are not satisfied with the status quo or with the traditional practices of racial separation since they have discovered that, apart from being unchristian, they cannot meet the needs of an increasingly integrated society.

\section{Forces of separation or reconciliation: Which will conquer?}

In this address it has been impossible to deal with the attitude of the average English-speaking white citizen of our country or of the non-white people of our land. The crucial question to be answered (from the Christian viewpoint) is: which forces will eventually conquer and prevail - those of increasing separation or of true reconciliation? The majority of our Afrikaners (and for that matter the majority of all whites in South Africa) seemingly believe that only in separate development can true reconciliation, peace and harmony be found. They regard this as the only basis for a just and orderly settlement of our racial problems. I do not hold that view, as I am convinced that this policy is morally indefensible and incapable of implementation. It is especially the Afrikaner who currently is in a position of power to decide our future course. Whether he will gain the wisdom and the moral insight to act on a basis of justice, equity and truth, I do not know. I do know, however, that our dilemma will only be resolved in the measure that all the inhabitants of our country, Afrikaans- and English-speaking, white and nonwhite, are prepared to determine all our attitudes and actions in race relations in 
the Spirit of Christ: his love of all men, his justice as proclaimed to all, his Kingdom including all who wish to obey and serve Him in spirit and in truth. 
Prof. D M Ackermann²

\section{The man and his context}

"There is a fascination about individuals who pit themselves against the might of a state, particularly when this involves a spiritual rebellion against their own community, with all the ostracism and pain that this brings," writes Peter Randall in an essay on the life and work of Beyers Naudé. ${ }^{3}$ Such individuals crop up in the histories of different societies. South Africa has been blessed to have individuals who have pitted themselves against the might of the state, women such as Emma Mashinini, Albertina Sisulu, Helen Joseph and Mama Zihlangu, and men such as Steve Biko, Walter Sisulu, Nelson Mandela and Desmond Tutu. What sets Beyers Naudé apart is the fact that he was compelled to take up a stance against his very own community and to pay the particular price that such action demands.

Who was Beyers Naudé? Born on 10 May 1915 in a parsonage of the Dutch Reformed Church (DRC), from an impeccable Afrikaner Calvinist background, Beyers Naudé was named after General Beyers, a staunch Afrikaner nationalist who headed a rebellion against South Africa's participation in First World War. His childhood and youth were typical of most patriotic and religious Afrikaners of that time. Not surprisingly, he decided to enter the ministry and went off to study at the University of Stellenbosch. ${ }^{4}$ There he revealed leadership qualities by being elected primarius of his residence and president of the student's representative council. Interestingly, signs of a rebellious streak emerged when he - together with several other students - started an anonymous campus newspaper called Pro Libertate (devoted to liberty and truth!) which raised controversy during its short life on the campus. After completing his theological studies, he became a minister in the Dutch Reformed church in 1939. In 1940 he was also formally and ritually inducted under oath of secrecy into membership of the Afrikaner Broederbond. ${ }^{5}$ This secret society was committed to Afrikaner domination of institutions of power in South Africa - the government, the economy, education, social institutions and the church.

1 Lecture given at the postgraduate research development workshop at the Beyers Naudé Centre for Public Theology at the University of Stellenbosch on 11 November 2004.

2 Denise Ackermann is extraordinary professor at the Department of Practical Theology and Missiology at the Faculty of Theology at the University of Stellenbosch

3 Peter Randall, "Not without honour: the life and work of Beyers Naudé" in Peter Randall (ed.), Not without Honour: Tribute to Beyers Naudé, (Johannesburg: Ravan Press, 1982), 1.

4 His lecturer in Sociology was Dr H. F. Verwoerd, later Prime Minister of South Africa, who was responsible for the development and consolidation of the policy of apartheid.

5 Randall, "Not without honour", 10. Literally meaning 'Afrikaner Brotherhood'. 
Beyers Naudé served as a minister to six congregations in various parts of South Africa. In 1953 he undertook a study tour of North America and Europe that further broadened his experience and his understanding of societies different to his own. ${ }^{6}$ In 1958 he was elected to the moderature of the Transvaal Synod of the DRC, an influential position which signalled that he was being prepared for higher office. One result of his new position was that he came into contact with younger and more sceptical DRC dominees who were questioning the application of the Group Areas Act and the race classification of the coloured community. ${ }^{7}$ Tensions had begun to surface within the DRC. A series of informal meetings took place in the homes of disaffected members in an attempt to deal with the deplorable ignorance of white DRC members with regard to the implications of segregated structures in church and community.

An event then occurred that was to change the course of history in South Africa. On 21 March 1960 a crowd of black people protested peacefully against the pass laws outside the police station at Sharpeville, an African township near Vereeniging. Police opened fire; sixty-nine protestors were killed and hundreds others wounded. According to Peter Walshe, this incident signalled the culmination of a decade of "sporadic black passive resistance". ${ }^{8}$ Roman Catholic Archbishop Denis Hurley, commenting on the effect of Sharpeville on Beyers Naudé, writes: "Out of that tragedy God spoke to Beyers Naudé". 9 A state of emergency followed Sharpeville; the African National Congress and the PanAfricanist Congress were banned; the already draconian security apparatus was tightened; capital flowed out of the country; the economy slumped and Verwoerd withdrew South Africa from the British Commonwealth. Tensions between English-speaking multi-racial churches and the state increased. 10 "Afrikanerdom was rocked to the foundations by the Sharpeville massacre. How could a policy designed to reduce friction lead to such violence?" comments Johan Kinghorn. ${ }^{11}$

The second crucial event in the life of Beyers Naudé was the Cottesloe Consultation, which took place in December 1960. The initial move for this consultation came from Anglican Archbishop Joost de Blank with the support of

6 It is important to note the influence on Beyers Naudé of his colleague Ben Marais in the Pretoria East Congregation. Marais's book Die kleur krisis en die Weste (The colour crisis and the West), raised critical questions regarding segregation, race and human dignity in the church. A further influence was Prof. B B Keet, whose book Suid-Afrika Waarheen? (Whither South Africa?), published in 1955, caused a stir in the DRC as it held that apartheid was a betrayal of the Christian calling.

7 "Coloured" was the term used during apartheid times to describe people of mixed racial origins.

8 Peter Walshe, "Mission in a repressive society: The Christian Institute of Southern Africa" in Randall (ed.), Not Without Honour, 52.

9 Denis E. Hurley, "Beyers Naudé - Calvinist and Catholic" in Randall ed., Not Without Honour, 71.

10 Randall, "Not without honour", 17.

11 Johan Kinghorn, "Modernization and apartheid: the Afrikaner churches" in Richard Elphick and Rodney Davenport (eds.), Christianity in South Africa: A Political, Social and Cultural History (Cape Town: David Philip, 1997), 148. 
the World Council of Churches (WCC) and its member churches in South Africa, which included the Cape DRC, the Transvaal DRC and the Nederduitsch Hervormde Kerk (NHK). Eighty representatives from the South African churches and six WCC representatives met from 7 to 14 December 1960. It is clear from subsequent accounts that many of the participants were deeply affected by their experience of this international, ecumenical and interracial gathering. For Beyers Naudé it was the first experience of true ecumenism. ${ }^{12}$

Cottesloe, a symbolic watershed in the life of Beyers Naudé, caused one "of the most acrimonious debates in the history of Afrikanerdom between 1950 and $1980 "{ }^{13}$ Although its findings were modest, Cottesloe did go to the heart of the policy of apartheid and its resolutions were in direct conflict with Prime Minister H F Verwoerd's policy of total territorial separation.

"Most important [the Cottesloe resolutions] recognized all racial groups as 'indigenous' and as citizens of South Africa and demanded equal rights for all to participate in the life of the country and to share in the responsibilities, rewards, and privileges of citizenship. It asserted that there were no scriptural grounds for the prohibition of mixed marriages; it acknowledged that wages received by the 'nonwhite' majority were below subsistence level, and affirmed that the right to own land 'wherever he is domiciled, and to participate in the government of his country, is part of the dignity of the adult man $[\text { sic }]^{\prime \prime} .{ }^{14}$

Beyers Naudé attempted to explain these findings to his people. A storm broke over his head. To Verwoerd and his followers, Cottesloe meant treason in Afrikaner ranks. The Prime Minster called on the churches to rid themselves of their betrayers, and they did. Severely reprimanded, the DRC delegates were stripped of their synodical duties, and opposition to government polices in the DRC was stifled. As debate closed down in the Afrikaner establishment, it was kept alive by small groups within the DRC, often in home-based Bible study groups. As a result of this crackdown Pro Veritate, a monthly Christian journal appeared in May 1962, edited by Beyers Naudé and overseen by an ecumenical, multiracial board. During this period Beyers Naudé became convinced that effective change could only take place outside the official framework of the mainline churches. According to John de Gruchy, "[t]he idea of forming a confessing church in South Africa, similar to that born during the struggle in Nazi Germany, had long been debated in South Africa. It had inspired Beyers Naudé to

12 Randall, "Not without honour", 19.

13 Kinghorn, "Modernization", 148.

14 Kinghorn, "Modernization", 148-149. 
launch the Christian Institute."15 This ecumenical and interracial body came into being in 1963 with Beyers Naudé as its director.

The next two years were times of turmoil and personal conflict for Beyers Naudé. Here was a leading candidate for moderator of the General Synod of the DRC and a true Afrikaner taking a stand that was extremely threatening to the foundations of Afrikaner civil religion. In 1963 he was elected as moderator of the Southern Transvaal Synod of the DRC. "This despite Cottesloe, despite Pro Veritate, despite his resignation from the Afrikaanse [sic] Broederbond: Could he have made a mistake after all; was the church in fact ready for change? Or was it a strategy to tempt him into compromise; was it pressure to bring him back into line?" asks Randall. ${ }^{16} \mathrm{He}$ was soon to know. Virulent attacks on the Christian Institute (CI) and on his person increased and finally he was faced with an ultimatum. He was called to resign from Pro Veritate and had to choose between the $\mathrm{CI}$ and his position as a minister of the DRC. He chose the Christian Institute. ${ }^{17}$ After serving six different congregations over his twenty-three years as a minister of the DRC, Beyers Naudé, preached his last sermon to a packed church at Aasvoëlkop, Johannesburg, on 22 September $1963 .^{18}$ Then, in a gesture symbolising the stripping of his status, he took off his robe before a silent congregation, some of whom were weeping. ${ }^{19}$

I have devoted time to recounting certain events in the life of Beyers Naudé in order to illustrate the changes that occurred in his life. I came to know him in the seventies through my membership of the $\mathrm{CI}$ and gratefully acknowledge the lifechanging role he played in my life as I struggled to live my faith in apartheid times. In the CI I met an eclectic group of Christians, some of whom were members of the Black Consciousness Movement (BCM), who spoke about liberation and black theology, poetry and drama and who openly envisaged a future in which black people would exercise political power. Those were heady days. Not surprisingly they came to an end abruptly when the CI was banned in October 1977. The above few sentences do not communicate the excitement and the dangers of those times. The CI's Cape Town offices were twice set alight; shots were fired at the home of Theo Kotzé, its director in the Western Cape and a leading light in the anti-apartheid struggle who eventually went into exile. Beyers Naudés passport was confiscated; ties between the Reformed churches in the Netherlands and those in South Africa were broken, and the Soweto riots of 1976 shocked the world. In

15 John W. de Gruchy, “Grappling with a colonial heritage: The English-speaking churches under imperialism and apartheid" in Elphick and Davenport (eds.), Christianity in South Africa, 167.

16 Randall, "Not without honour", 22.

17 Alan Paton commented as follows: "One is forced to conclude - because one does not reach such a conclusion lightly - that this is the work of the Holy Spirit and that Beyers Naudé was struck down on some Damascene road". See "Church and State in South Africa", Christianity and Crisis, September 1974.

18 See pages $25-29$ of this publication - ed.

19 Randall, "Not without honour", 29. 
1976 the security police continued their harassment of the CI, regularly searching its offices, while political rhetoric against the CI heated up. In 1977 Steve Biko, the first president of the South African Students Organization and a leading black consciousness leader who was closely involved with the $\mathrm{CI}$, was murdered in detention. Shortly thereafter the $\mathrm{CI}$, together with seventeen other organisations mainly black consciousness groups - was declared an unlawful organisation, its offices were closed down and all its documents confiscated. This event also signalled the end of Pro Veritate. At the age of sixty-two, Beyers Naudé was subjected to a banning order that restricted him to his home, cut him off from attending meetings of any kind, whether social, political or religious, did not allow him to speak in public and made it unlawful to quote him. Commenting on this kind of punishment Peter Randall writes:

"Banning causes a profoundly damaging loss of spontaneity in one's human relationships. There is the risk of developing a permanent attitude of distrust towards new contacts - and even some old contacts - and a general feeling of suspicion: could they possibly be agents of the system....The loss of spontaneity in terms of Christian fellowship must have hit the Naudé's particularly hard. Expressions of fellowship, for a banned person, are limited to meeting with one other at a time; for a couple or a family there is not legal opportunity to experience anything of the fullness of Christian community." 20

Public Christian witness in fact became a forbidden activity. This was a period of intense frustration and very hard on Beyers Naudé, his wife Ilse and his family. Originally banned for five years, his banning order was subsequently extended for a further three years and then, to his surprise, lifted after a total of seven years on 26 September 1984. Barely a month later he was approached by the leaders of the South African Council of Churches (SACC) to succeed Desmond Tutu, who had just been appointed bishop of Johannesburg. He accepted reluctantly. "I was white, for many years I belonged to a church that defended apartheid on biblical grounds, I was already sixty-nine, and after seven years of banning...I had not had much contact with what was happening in my country and particularly in the black churches....Moreover I was very hesitant to stand in Desmond Tutu's shoes...". ${ }^{21}$ However, he accepted the position and served as secretary of the SACC from 1985 to 1988 .

During that time and thereafter Beyers Naudé continued to speak, teach and preach about the need for confession, reconciliation and unity among the churches. He pleaded ceaselessly for the DRC to become one united church. Ecumenism,

20 Randall, "Not without honour", 41.

21 Beyers Naudé, My Land van Hoop (Cape Town: Human and Rousseau, 1995), 124. All quotations from this work are translated by me. 
economic justice, love and the value of the human person were his abiding themes. He led protest marches and visited sites of struggle, suffering and conflict. I have an abiding memory of him at the funerals of young black activists - often the only white face.

This potted biography does not do justice to a man whose integrity and personal charm, whose courage and honesty and above all whose prophetic humility set him apart from his contemporaries. Suffice it to say that the moving homage paid to "Oom Bey" 22 after his death by the South African nation speaks volumes for the high regard in which he was held. After these glimpses into his life, I shall now attempt to assess Beyers Naudé as a public theologian.

\section{On being a public theologian}

In South Africa the explicit use of the term "public theology" is fairly recent. This does not mean that public theology was not practised in a variety of ways, particularly in opposition to apartheid. According to Nico Koopman, public theology is found in publications, seminars, conferences, public declarations, civil protests such as marches, hunger strikes and memoranda to the government, welfare programmes and the quest for economic and political justice, and even in an official confession (The Confession of Belhar, 1986). ${ }^{23}$

There are of course different understandings of what is meant by public theology. For some it is the need to explain, justify and defend theological claims in a public way and to seek at least a degree of consensus and universality, as represented by David Tracy's critical correlation approach. David Hollenbach describes public theology simply as "the effort to discover and communicate the socially significant meaning of Christian symbols and tradition" which serves the church as well as society. He continues - "Public theology wants to bring the wisdom of the Christian tradition into public conversation to contribute to the well-being of society". ${ }^{24}$ Martin Marty believes that "purely private faith is incomplete". He continues: "Public theology wants to bring the wisdom of the Christian tradition into public conversation to contribute to the well-being of society". ${ }^{25}$ Lastly, Robert Simons explains that "When theology is described as public, the meaning of "public" is that such theology is accessible to intelligent, reasonable and

22 "Oom Bey", literally "Uncle Bey", was the name by which he was affectionately known by the many South Africans who knew and loved him.

23 Nico Koopman, "Some comments on Public Theology Today". Journal of Theology for Southern Africa, $117,2003,3-19$.

24 David Hollenbach, "Editor's Conclusion". Theological Studies, 40, 1979, 700-715.

25 Martin Marty, "Foreword" in R. Levin (ed.), Religion and American Public Life (New York: Paulist Press, 1986), 1-4, at 1. 
responsible members of a society, despite otherwise crucial differences in their beliefs and practices" ${ }^{26}$

I have argued that public theology as public practical theology not only affirms the public character of all theology but points to the fact that theology lives in the tension between theory and praxis, between what we believe and what we do about what we believe. Public practical theology that is done in service of the reign of God comes out of a critical consciousness informed by social analysis, a concern for justice, the creative use of human imagination and the willingness to risk actions that express our hope for a better world. ${ }^{27}$ All these understandings of public theology assume that the church is sensitive to the public order that surrounds it and with which it desires to be in communication.

In the light of these understandings the question arises: was Beyers Naudé a public theologian and, if so, what kind of public theologian?

Before tackling this question, I want to refer to Ronald Thiemann's paper "The Public Theologian as Connected Critic" delivered in Prague, June 2003. I was struck by his caution that the churches' contributions to the res publica need "a clear and authentic understanding of their status as public theological institutions" and his description of their role as that of "connected critics". Connected criticism, according to Thiemann, "oscillates between the poles of critique and connection, solitude and solidarity, alienation and authority. Connected critics are those who are fully engaged in the very enterprise they criticize, yet alienated by the deceits and shortcomings of their own community". ${ }^{28}$ Thiemann's understanding of a "connected critic" is my entry point for attempting to answer the question posed above. I shall, with reference to Thiemann's description of the connected critic and to my own understanding of public practical theology, argue that Beyers Naudé was eminently a public theologian.

\subsection{Beyers Naudé, a connected critic}

\subsubsection{Critique and connection}

In the early part of his life Beyers Naudé was not critical of his context and background. Describing this background, he told Dorothee Sölle - in a published conversation - that he came "from a very conservative, deeply religious Afrikaner [sic] home ... [my] whole background is one of a deeply religious, strongly

26 Robert G. Simons, Competing Gospels: Public Theology and Economic Theory (Alexandria, NSW Australia: E. J. Dwyer, 1995), xv.

27 Denise M. Ackermann, "'Doers of the Word'? Public theology as public practical theology", paper read at the Centre of Theological Inquiry's (CTI) Conference on Public Theology in Central Europe, Prague, June, 2003.

28 Ronald F. Thiemann, "The public theologian as connected critic", paper delivered at the CTI Conference on Public Theology in Central Europe, Prague, June 2003. 
nationalist Afrikaner tradition". ${ }^{29}$ His rise in the hierarchy of the DRC, his membership of the Broederbond, his professional path as a minister, would not have been possible had he been a critical member of his community. It demanded loyalty which he described as follows: “...in the Afrikaner society there is such a deep sense of loyalty... Loyalty to your people, loyalty to your country, loyalty and patriotism have in a certain sense become deeply religious values... So that anybody who is seen to be disloyal to his nation, to his people, is not only deemed to be a traitor, but in the deeper sense of the word, he is seen as betraying God." 30 He understood this loyalty (and subsequently its traps), and he never lost his deep connection with his own people.

Despite remaining an Afrikaner in body, mind and soul, Beyers Naudé became a fearless critic of his people, precisely because he cared for them and remained deeply connected to them. His coming to critical awareness was a process, as described above. Critical awareness was followed, quite naturally, by the need for change-making actions. Critique and the active seeking of change do not sit comfortably in a society that demands loyalty and baulks at change. Beyers Naudé knew what it was like to be torn between loyalties to one's family, friends, church and people on the one hand, and the injustice and suffering caused to the majority of South Africans, on the other. Talking about forced removals to Dorothee Sölle, he said: "And, you know, I must feel the agony of this, especially because I know that the people who are in control and in power doing this, these are my people. I cannot deny that I am an Afrikaner. I don't want to deny it. How can I? I am nothing else but an Afrikaner, and yet in that sense I don't see myself to be there...". 31

The establishment of the CI under his leadership was a major turning point in Beyers Naudé's life. Writing about its establishment, he stated that the CI was an organization born in the church and that it wanted to work in the church, not in a competitive manner but supportively. ${ }^{32}$ Remaining connected to the church was a primary consideration throughout his life. But the church is more than the white DRC. The separation of the white DRC from the black family of Dutch Reformed churches was intolerable for Beyers Naudé. "No one who loves the church as the Body of Christ can ever be happy about this state of affairs", he wrote. ${ }^{33}$ He saw his church undergoing a "purposeful and fear-ridden process of isolation". ${ }^{44}$ Through his work in the CI, Beyers Naudé developed a profoundly ecumenical understanding of the church, while at the same time remaining a faithful member

\footnotetext{
C.F. Beyers Naudé and Dorothee Sölle, Hope for Faith: A Conversation, (Geneva: WCC, 1986), 4.

Naudé and Sölle, Hope for Faith, 11.

Naudé and Sölle, Hope for Faith, 9.

Beyers Naudé, “Die Christelike Instituut en die Kerk". Pro Veritate,6, 8, December 1967.

Pro Veritate, 6, 8, December 1967, 4.

International Commission of Jurists (ed.), The Trial of Beyers Naudé: Christian Witness and the Rule of Law (London: Search Press, 1975), 10.
} 
of the Dutch Reformed family of churches. His understanding of the church was inclusive: "If we mean by church mainly the institution, the structure, the visible, traditional symbols, then I believe that the church, in that sense, will experience one crisis after another, until it comes to the recognition, understanding that the church in the real sense of the word, is where the people of God are, where life is being discovered again, the true meaning of love, of human community, of mutual concern for one another, of caring for people, of seeking true meaningful relationship, understanding between people, not only between Christians, but between all people." ${ }^{35}$

Beyers Naudé's commitment to ecumenism is clear from a statement he made before the Schlebusch Commission set up in February 1972 to investigate certain organisations, including the $\mathrm{CI}$. He described the $\mathrm{CI}$ as follows:

"The Christian Institute is an organization of individual Christians from all churches in South Africa, with four main aims and objectives. In the first place, to give a more visible expression to the biblical truth of the unity of all Christians, all believers. In the second place, to relate the truth of the Gospel more immediately to the questions of our daily existence and to make its meaning more clear to its members and to all who wish to know it. In the third place, to act as a group of Christians who wish to help bring about reconciliation between the widely divergent, divided and conflicting groups of Christians of different Churches and colours in our country. And in the fourth place, to offer the services of our members to any Church or group of Churches who wish to make use of them to give a better expression of the Kingdom of God in South Africa." ${ }^{36}$

Once he had committed himself to the CI which, in his words, "seeks deep and radical change, in repentance and faith, obedience to the will of God and the transformation of society in his name", ${ }^{37}$ his critical voice became clear and unambiguous. He described the CI as "a fellowship of Christians who seek individually and together to be used by God to give practical expression to a growing desire for fellowship and understanding between Christians in our country". ${ }^{38}$ Writing in Pro Veritate, he said that the CI was convinced "that bringing every facet of life into obedience to Christ means rejecting the heresies of racism, apartheid and 'Christian nationalism'". ${ }^{39}$

35 Naudé and Sölle, Hope for Faith, 21.

36 See International Commission, 55. Recounting this event in his autobiography (p.100), he recalls how he refused to pay the fine imposed on him and went to jail for a night instead, where he read Amos and then slept like a $\log$ (soos ' $n$ klip geslaap), before a friend bailed him out the next morning.

37 Pro Veritate, 13, 1, May 1976, 10.

38 International Commission, 11.

39 Pro Veritate, 13, 1, May 1976, 10. 
Clearly he had set himself on a collision course with his own people and their policies. In 1976 he wrote: "Majority rule will be coming to South Africa in the next decade...[because] the culture of any community cannot be secured by entrenching itself in isolation or by ensuring its future existence through selfish legislation, but only through the inner vitality of its culture, its moral values and its willingness to serve its fellow men. And this is the challenge that every minority group in South Africa has to face today". ${ }^{40}$ These and many similar views, expressed in Pro Veritate, resonated with black Christians who suffered discrimination and alienation from white Christians who supported traditional DRC views on apartheid. They felt connected to the CI and its mouthpiece and saw them as beacons of hope in dark times. An unknown black man wrote in Soweto in 1971: “Every night I hurry into my room where I light my candle and take Pro Veritate from under my mattress to read. Then my heart is full of hope and I thank Christ. Then I can go to sleep". ${ }^{41}$

\subsubsection{Solitude and solidarity}

In his autobiography Beyers Naudé's chapter on his banning is called "Sewe maer jare" (seven lean years). Faced with being cut off from all his previous activities and interests, he recounts how he was faced with three options. First, he could devote himself to further theological study and learn a black language; second, he could write a book about the questions and problems that had brought him to this place; third, he could leave South Africa so as to further the cause of the CI in exile. He wrestled with these options, but when his wife Ilse said: "If you feel that it is your duty to go, do so, but do not expect me to follow you", he dropped the third option. Instead he decided to expand his contact with members of the Black Consciousness Movement and to find ways of helping those who were opposing apartheid..$^{42}$

This was not an easy decision. Describing his experience of his banning, he tells Dorothee Sölle: "... and the moment they succeed in making you a non-person, whatever you say, therefore, loses significance and loses meaning, and therefore in that sense they invalidate what you are saying, and ...remove the danger that the ideas and thoughts that you present could therefore have some impact." 43 Beyers Naudé knew a kind of solitude, albeit an enforced solitude which he subsequently described as the most enriching time of his life. In his enforced solitude he found solidarity.

40 Beyers Naudé, “On Majorities and Minorities", Pro Veritate, 14, 11, April 1976.

41 Quoted in Roelf Meyer and Beyers Naudé, "The Christian Institute: A short history of a quest for Christian Liberation", in Ian Liebenberg, Fiona Lortan, Bobby Nel, Gert van der Westhuizen (eds.), The Long March: The Story of the Struggle for Liberation in South Africa (Pretoria: HAUM, 1994), 164.

42 Beyers Naudé, My Land van Hoop, 115-116.

43 Naudé and Sölle, Hope for Faith, 15. 


\begin{abstract}
"They came to our front door, one by one, day after day, black but also white, young but also old, from early in the morning to well after dark and sometimes deep into the night. And as I began to discover how little I really knew about what lived deep in the hearts of the majority of our population, I began to realise that I must use my banning to listen and to learn. Thus seven years of listening and learning followed and the seven leanest years of my life became the seven richest years of my life." 44
\end{abstract}

He became involved in the illegal activities of the African National Congress (ANC) as he supported young activists intent on joining the military wing of the ANC. He records that he always asked each one of them the same question: are you sure that you have no other option? He assisted in disseminating ANC literature and helped, with small sums of money, some young people who went into exile or crossed the borders seeking military training. Most of all, he built up relationships of trust with members of the BCM as well as with members of the liberation movements and came to make their cause his own.

\title{
2.1.3 Alienation and Authority
}

Beyers Naudé attests to the blessings of his seven years of banning. It was not primarily an experience of alienation. This does not mean that he did not experience alienation, particularly from his own people. His persecution by the state and his increased support for the liberation movements alienated him more and more from his own people. His support of the WCC's Programme to Combat Racism was greeted with shock and horror by his own community when, in 1970, the WCC granted R143, 000 for non-military purposes to the liberation movements in South Africa. His support for this grant had consequences which he described in an article as "The Parting of the Ways". "Die tyd vir vroom woorde is verby" (the time for pious words is past), he wrote in Pro Veritate. ${ }^{45}$ In his view South Africa was now separating itself from the world community by the further enforcement of racist rule. This was also a testing time for white people who had to face the rightness of the black cause and black majority rule. Finally, it was a decisive time for the DRC which had to decide whether to continue to support apartheid or to work for a new South Africa. ${ }^{46}$

As he inveighed against the apartheid state, as his alienation from his own people grew, his moral authority and stature grew. His voice, though crying from the wilderness, was a voice that gave hope to the millions who saw in him a man of prophetic courage and deep and abiding moral values precisely because he had dared to confront his own community. In an article entitled "The South Africa I

44 Beyers Naudé, My Land van Hoop, 116.

45 Pro Veritate, 9, 6, October 1970.

46 Beyers Naudé, “Die skeiding van die weë". Pro Veritate, 9, 6. October 1970. 
want", Beyers Naudé wrote that he did not want authoritarian rule or a political ideology based on a system of separate advantages for whites and control of people's movements. He wanted the permanency of all South Africans to be recognised, freedom for all, black political representation, the pass laws repealed and free compulsory education for all South Africans.

Whatever it is that confers moral authority on a human being who is willing to suffer for her or his beliefs, who identifies with the suffering of others in visible and practical ways, who is prepared to face alienation from her or his own community, and who is quite clearly a person whose actions and thoughts are undergirded by profound faith, Beyers Naudé possessed this. Above all, he was a person of extraordinary humility. He had an almost childlike acceptance of and belief in the ultimate goodness of humanity. Self-effacing, open and always hopeful, Beyers Naudé gained a moral stature rare in these times.

\section{Beyers Naudé, public theologian}

Ron Thiemann's categories for evaluating a "connected critic" are not divorced from my understanding of a public theologian. Thiemann writes: "Connected critics are those who are fully engaged in the very enterprise they criticize, yet alienated by the deceits and shortcomings of their own community" (my italics). ${ }^{47}$ For 'fully engaged' I read 'praxis', action or 'the doing of the word'. In the paper I gave in Prague in June 2003, I concluded that public practical theology was theology involved in praxis for the reign of God. "Public practical theology takes praxis, the 'doing of the word', as the measure by which its integrity and its authority will be judged in the public square". .8

I never heard Beyers Naudé refer to himself as a public theologian. He would probably have rejected labels and simply called himself a servant of Christ. Yet his life and work met the criteria of a public theologian who, in Hollenbach's words, wanted - with passion and courage - to "bring the wisdom of the Christian tradition into public conversation to contribute to the well-being of society". He was without doubt "fully engaged" in actions that expressed the values of the reign of God: justice, love, freedom, peace, wholeness and the flourishing of righteousness. He was primarily driven by his desire to be obedient to where his God was leading him. He could in a sense do no other. His life was quite simply an active living out of his faith in a highly charged public arena at a particular time in South African history. ${ }^{49}$

47 Thiemann, "The public theologian", 11.

48 Ackermann, "Doers of the Word?"

49 In a sermon delivered to his congregation in Aasvoëlkop in 1962, Beyers Naudé set out his credo. He had to counter suggestions that he was propagating a false gospel. Taking I Cor. 2:2 as text for this sermon, he set out his beliefs. The Bible is the only true Word of God given to humanity as guiding principle for belief and life and as such it has authority over our lives. He confessed his 
In his farewell sermon to the Aasvoëlkop congregation in 1963, he chose Acts 5:29 as his text. After a straightforward exegesis of the text, Beyers Naudé turned his attention to the difficult question: in situations of conflict how do we know that we are in fact obeying God rather than "man"? Through our conscience? How do we know that our conscience is right? He talked about his own struggle to find reasons to cut his ties with Pro Veritate and the CI, something the Southern Transvaal Synod of the DRC insisted on if he wanted to keep his status as a minister in his church. "But time and time again, at times with great agonizing, fear and resistance in my heart, the Lord brought me back to this part of Scripture, as if he wanted to say: Whatever this text may mean to others, this is my answer to you: obey God rather than man"..$^{50} \mathrm{He}$ then explained that the choice went deeper than his concern for his pastoral work, the church, Pro Veritate or the CI. "It is a choice between religious conviction and submission to ecclesiastical authority. By obeying the latter unconditionally I would save face but lose my soul".$^{51}$ He then addressed his congregation and his church. He concluded with these words:

"If the NG Kerk does not understand and exercise more deeply this obedience demanded by God, then we will suffer endless loss and sorrow....If our Church continues with this deliberate and fearinspired process of isolation, with its tragic withdrawal from the Holy Catholic Church in South Africa, in Africa, we will spiritually wither and die....Oh, my Church, I call this morning in all sincerity from my soul - awake before it is too late. Stand up and give the hand of Christian brotherhood to all who sincerely stretch out their hand to you. There is still time, but the time is short, very short." 52

His plea was not heeded. His words were indeed prophetic. Today the white DRC is still struggling to come to terms with its history, with its separation from its "sister" churches and with the experience of being truly ecumenical.

Duncan Forrester writes: "Truth is not something to be comprehended, controlled, used or appropriated. It is rather to be indwelt, lived out in action and witnessed

faith in Christ "the eternal and only Son of God". He confessed his faith in an inclusive church which shares communion with all its members equally and which calls us to love our neighbours in all our differences. He affirmed his belief that a group, nation or civilization can only be assured of God's care if it practises justice and seeks the truth. Lastly, he affirmed the prophetic calling of the church to speak on matters of justice, charity and compassion. He then asked his congregation: "Do you believe this?" This sermon was nothing more than a simple statement of reformed faith.

51 Beyers Naudé, My Land van Hoop, p. 159.

52 Beyers Naudé, My Land van Hoop, p. 160. When this sermon was quoted at his trial ten years later, the advocate for the defence asked him: "Now, Mr. Naudé, in the ten years since you preached that sermon have you had any reason to change your opinion in any way?" He answered: "No. In the past ten years that opinion has only been deepened, broadened and confirmed." 
to. And that is what Christian public theology is about today."53 Beyers Naudé lived his faith with consistency, courage and hope. His witness was that of a public theologian who devoted himself to the cause of human dignity and justice in South Africa through very demanding times. He was a prophet outside the walls of the church, who loved the church to the end and is assured of an honoured place in the painful story of South Africa's transition to democracy.

53 Duncan B. Forrester, Truthful Action: Explorations in Practical Theology (Edinburgh, T \& T Clark, 2000), 139. 


\section{STEVE BIKO: THE MAN AND HIS MESSAGE}

Beyers Naudé

Steve Biko: The Man and His Message - This is what I have to talk about. I have no problem in doing so except to say that I know that this is impossible to do justice to a person whose breadth of vision, whose true humanity, whose outstanding talents, whose deep commitment to his ideal and whose political wisdom placed him in the category of a future Prime Minister of our country. And Prime Minister, I believe, he would have become had his life been spared to play this significant role.

My dilemma is, however, that I have to speak to a white or predominantly white audience about a South African of whom $90 \%$ of white South Africans know little or nothing. This is but another proof of the tragedy and the danger of the abysmal ignorance which the policy of racial separation has created about leading and outstanding black personalities who, in any normal society, would have been widely known and acclaimed, but whose death in our society now calls for the incredible response from so many: "But who is Steve Biko?" Here we also find another proof of the despicable system of bannings whereby the public at large is deliberately prevented from being exposed to the creative and challenging ideas of such a person as Steve Biko. In the case of Steve it did not and could not succeed, however, because his beliefs and actions were so vital, so relevant, to his whole community and following that it could not be confined in a banning order or to a prison cell. This is the stature of the man we are talking about.

Who was Steve Biko? He was one of the most outstanding black leaders this country has ever produced - a person of the same quality and stature as Albert Luthuli, only more so. Young in years yet exceptionally mature in insight and wisdom, with a sharp analytical mind which unerringly and rapidly led him to focus any discussion on the heart of an issue and to present its essential solution. In addition to that, a person with a depth of commitment to the cause of black liberation which won him the admiration and devotion of all young blacks as well as the respect of all his people. Thus he became the creator, the leading representative and the most able exponent of the black consciousness movement. But above all he was a person with a deep respect for every human being regardless of race, a Christian with a deep concern for all his fellow men. That is why he towered above all radical prejudice, all class distinctions, all ethnical and tribal loyalties. His was a commitment to humanity as a whole and the recognition of the dignity of every human being. Is it therefore surprising that he simply could

$1 \quad$ Address delivered at the Citizen's Protest Meeting, Johannesburg, September 19th 1977. 
not and would not fit into such a society which subscribed so willingly and obeyed so slavishly to a set of moral and social values which Steve utterly rejected? This man is the man South Africa has lost - and could not afford to lose. This man who has been sacrificed on the altar of separate development.

What was his message? I believe that Steve Biko's witness will grow in influence and significance as the years advance but to-day already his life and death has a three-fold message:

1. A message to the black community: It would be presumptuous for any white man to try and present his message. I do not believe that any white man has the right or the moral authority to convey this message to the black community. There is also no need for this. This response of the millions of blacks to Steve's vision and leadership is clear enough proof of how fully that message was understood, accepted and gladly responded to, even if this entailed suffering, sacrifice and death because they knew that it was a message of liberation for themselves and everybody else in our country.

2. To the English-speaking white community: But Steve Biko is also addressing himself through his life and death to the English-speaking South African community - including the white liberals. To the growing number of conservative, English-speaking people supporting the Government out of fear and/or self-interest Steve is saying: You are building your future existence on a false security. Break away from the illusion that this road will bring you the safety and security you are so anxiously seeking.

To the white liberal Steve is saying: It is no longer good enough to voice your opposition to apartheid or separate development only through motions and resolutions. You should go further: you should become truly committed to the cause of freedom by your willingness to relinquish illegitimate privilege and power and to share it with all the people of the land. You should participate more actively and meaningfully in a radical programme of non-violent action to bring about fundamental social and political change. 
3. Aan die Afrikaner gemeenskap²: Maar Steve Biko se lewe het ook 'n spesiale boodskap vir die Afrikaner-seksie en vir elke individuele Afrikaner. Dis die Afrikaner met sy heroïese geskiedenis en offerhande vir 'n grootste ideaal en sy strategie wat ook as sterk impetus gedien het vir Steve om sy konsep van swartbewussyn en sy strategie van swart solidariteit te ontwerp en in toepassing te bring - nie om die Afrikaner daarmee te bedreig nie, maar as hy gewillig is, hom te help om hom van sy ideologiese verknegting te bevry en in te lei in 'n groter en omvattende Suid-Afrikanerskap waarin daar genoegsame ruimte sal wees vir alle mense, alle groepe, klasse, rasse en kulture - maar dan

2 3) To the Afrikaner community: But Steve Biko's life also has a special message for the Afrikaner segment and for every individual Afrikaner. It is the Afrikaners with their heroic history and sacrifice towards a grand ideal and their strategy that also served as strong impetus for Steve to develop his concept of black consciousness and his strategy of black solidarity and to put them into practice not to threaten the Afrikaners with this but, should they be willing, to help liberate them from their ideological servitude and to introduce them to a greater, comprehensive concept of being South African that will accommodate all people, all groups, classes, races and cultures - but not as members of a privileged elite claiming for themselves the right to rule the lives of others and to determine their identity.

Therefore Steve Biko's death speaks to the Afikaners especially, challenging them to undertake a new heroic task. That is what Steve Biko would have told the Afrikaners if he was given the opportunity, if his promising life was not cut short so prematurely and inexplicably. Even if his death left you Afrikaners cold, I would like to say to you that your lives and your future did not leave him cold - on the contrary, it concerned him deeply. For the Afrikaner, too, he wanted to create room as a person of equal value in the new South Africa. His untimely death plunged our country into an extremely serious crisis with far-reaching and unforeseeable results for the whole of the country.

So, should you ask me what message Steve Biko's life has for the Afrikaners that we should heed today, I would say it was this: break free from the prison of your subservience to an ideology that is leading our country towards disaster and that can destroy the Afrikaners as well. Break free from this ideological system that is enslaving and suffocating your whole life. Do not seek security in weapons, in an exclusive identity or in clinging to false loyalties. Realise that the solution to our problems will not be found within the framework of separate development. Stop talking behind closed doors or in the boardrooms of white political power over black people and stop taking decisions on their behalf. Step outside and meet with black people, as they offer themselves in all sincerity to you. Grab the hand of friendship that is still being extended, even at this late hour, to you as Afrikaners and as white rulers of this country, and say to them: let us plan and determine the future of this country together. Let us seek peace together in this torn, tragic, divided South Africa.

Won't there come to the fore, from the ranks of our Afrikaner academics, our Afrikaner youth, our Afrikaner workers, yes, even from that of our Afrikaner ministers men and women willing to say: Steve Biko's death has opened my eyes to what is truly happening and to all that is at stake; Steve Biko's message has taken hold of me and it will not release its grip; Steve Biko challenges me to not keep quiet any more but to voice my deepest convictions about what is right and true, to stand up for them and to suffer for them if necessary - even if this should mean that I would have to endure condemnation and rejection by my people; Steve Biko's death has helped me to wake up to my life, my true liberation. If this is to be the impact of Steve Biko's death on a significant part of the Afrikaner people, then Steve Biko did not live in vain. In fact, then he and his message have started to truly live only now. 
nie as 'n bevoorregte elitegroep wat homself die reg toeëien om ander se lewens te beheers en hulle identiteit te bepaal nie.

Daarom spreek Steve Biko se dood die Afrikaner in besonder aan en daag hom uit tot 'n nuwe heroïese taak. Dít is wat Steve Biko aan die Afrikaners sou gesê het as hom die geleentheid gegun was om dit te doen, as sy belowende lewe nie so ontydig en onverklaarbaar kortgeknip is nie. As sy dood $\mathrm{u}$ as Afrikaners koud gelaat het, wil ek aan $u$ sê dat $u$ lewe en $u$ toekoms hom nie koud gelaat het nie - inteendeel dit het hom diep aangegryp. Ook vir die Afrikaner wou hy 'n gelykwaardige plek as mens in die nuwe Suid-Afrika inruim. Sy ontydige dood het ons land in 'n uiters ernstige krisis gedompel - met ingrypende en onvoorsienbare gevolge vir ons hele land.

As $\mathrm{u}$ dus my sou vra wat die boodskap van sy lewe aan die Afrikaner is waaraan ons op hierdie oomblik gehoor moet gee dan sê ek dit is dit: Breek uit $\mathrm{u}$ gevangeskap van 'n slaafse navolging van 'n ideologie wat ons land op 'n ramp afstuur wat ook die Afrikaner kan vernietig. Breek uit 'n ideologiese sisteem wat $\mathrm{u}$ lewe verkneg en verwurg. Moenie $\mathrm{u}$ sekuriteit probeer soek in wapens, in eksklusiewe identiteit of in die behoud van valse lojaliteit nie. Besef dat die oplossing van ons probleme nie gevind kan word binne die raamwerk van selfstandige ontwikkeling nie. Hou op om agter geslote deure of in die raadsale van blanke politieke mag oor die swartman te praat en vir die swartman te besluit. Kom uit in die ope en ontmoet die swartman, soos hy homself in opregtheid aan u bied. Gryp die hand van vriendskap, wat selfs in hierdie late uur nog aan $\mathrm{u}$ as Afrikaner en as blanke heerser van hierdie land uitgesteek word, en sê aan hom: laat ons saam die toekoms van hierdie land beplan en bepaal. Laat ons saam die vrede van hierdie verskeurde, tragiese, verdeelde Suid-Afrika soek.

Sal daar dan nie uit die kringe van ons Afrikaner-akademici, ons Afrikanerjeug, ons Afrikaner-arbeiders, ja selfs ons Afrikaner-predikante, manne en vroue navore kom wat bereid sal wees om te sê: Steve Biko se dood het my oë oopgemaak vir wat werklik gebeur en vir wat alles op die spel is; Steve Biko se boodskap het my in die hart gegryp en ek kan nie daarvan los kom nie; Steve Biko daag my uit om nie langer stil te bly nie maar om my diepste oortuigings van wat reg en waar is nou uit te spreek en daarvoor te staan en te ly as dit nodig is - al beteken dit ook dat ek die veroordeling en verwerping van 'n deel van my volk moet verduur; Steve Biko se sterwe het my gehelp om my lewe, my ware bevryding te vind. As dit die uitwerking op 'n betekenisvolle deel van die Afrikaner volk gaan wees van Steve Biko se dood, dan het Steve nie verniet geleef nie. Inteendeel, dan begin hy en sy boodskap nou eers leef.

This is the message of Steve Biko, the man: will we heed it and respond while there is still time? 
Thank you very much for this opportunity and the warm welcome here this morning. I was delighted to listen to the other speakers. Margaret's lecture brought back so many memories; the most powerful was of Margaret herself as an activist. I don't think there's a more dramatic picture in my memory than of Margaret lying in front of the bulldozers in Crossroads, and daring the police to act against her. You're an example to us all. ${ }^{3}$

\section{First Impressions: Beyers Naudé: an enabler of people}

Beyers Naudé visited Chicago in 1963 when I was a student there. He was travelling around the United States, trying to contact South African students who were living and studying there at that time. He phoned one of my friends, a Dutch Reformed student from the Free State, Gerrie Rademeyer, and met with us. He shared his vision of the Christian Institute and said: "When you come back to South Africa, please call and see me and tell me about your experiences." Beyers was a wonderful enabler of people and this is why I start with this little account, because my experience of him is of one who was always trying to enable others to do things that they were passionate about in terms of their theology and the situation in South Africa.

Beyers Naudé was a man of great vision and commitment, but one who got beside people to enable them to pursue their vision as well. So when I returned I went to visit the offices of the Christian Institute which had been opened in Braamfontein a year or so before, and met with him there, and we talked about a number of things. We talked about the need for civil disobedience in South Africa, and the need for people to start thinking and writing about this. I remember I was thinking of doing some work in that direction. And at that particular moment Beyers said: "Shush not sure who's listening into this conversation." So I was taken into another room with Fred van Wyk, who was the assistant director, to talk about that. One thing led to another and I became involved in the CI and served on the editorial committee of Pro Veritate.

1 Tribute to Beyers Naudé delivered at the celebration of his $89^{\text {th }}$ birthday on 31 May 2004 at the Beyers Naudé Centre for Public Theology at the University of Stellenbosch.

2 John de Gruchy is professor emeritus at the University of Cape Town and is currently extraordinary professor at the Department of Systematic Theology and Ecclesiology at the Faculty of Theology of the University of Stellenbosch.

3 Reference to the address by Dr Margaret Nash at the same occasion. (See pages $31-40$ of this publication - ed.) 
Then a very interesting development took place. As was indicated earlier by other speakers, Beyers was very involved in the ecumenical scene internationally as well as in South Africa. There were a number of ecumenical events that took place in the mid-60s around the theme Pseudo-Gospels in South Africa. And one of the meetings took place at Marianhill, the Roman Catholic monastery near Durban. There, for the first time, I began to see some of the giants in the ecumenical movement - Beyers Naudé, Archbishop Dennis Hurley and others - reflecting theologically on the public issues that were facing us around the theme of pseudogospels or false gospels, apartheid being one of them. It was in that interaction that gradually emerged the joint declaration by the $\mathrm{CI}$ and the SACC that became known as the Message to the People of South Africa.

At the same time as this was happening Beyers had begun establishing the Bible study groups in various parts of the country. They had been going on for a quite a while by then - we had one in our manse in Durban, where I was a minister at the time. And we began to study the documents that were emerging out of the PseudoGospels Conference and also out of other conferences that were held to follow up the Church and Society Conference held in Geneva in 1966. That was a very important moment for Beyers Naudé. Already he was established as a prophetic figure in the South African situation. He went to the Conference in Geneva together with Bishop Bill Burnett, who was the new general secretary of the South African Council of Churches. When they returned they were asking exactly the question that one of the previous speakers has posed here this morning: What are we going to do?

Now, when you don't know what to do, you convene meetings. So they convened meetings around the country, following up on the Pseudo-Gospel ones, but now specifically for reflection on the Geneva Church and Society Conference. There had been for the World Council of Churches, and for the ecumenical movement in general, a very radical shift in focus at the time. A number of important things had also come into effect by 1966, not least of which was the impact of Latin American liberation theological thinking. This was very important in the reshaping of the thinking and focus of the World Council of Churches in terms of Church and Society issues. So we had these various workshops around the country on PseudoGospels and then Church and Society. At the same time, behind the scenes, there was a group at work drafting the Message to the People of South Africa.

Then in early 1968 a conference on Church and Society was held in Johannesburg where these different groups, or their representatives, participated in a big gathering of about 200 people. A dramatic moment at that conference was when a Methodist minister, Paul Welsh, who had been secretary to the Drafting Committee of the Message to the People of South Africa, got up and he read the Message. The atmosphere was electric. There were informers in the conference; there were also many people there who had come but who were not ready for this 
moment and very unsure about how to respond. Now, when looking back, it seems a little tame, but at that moment it was as though a bombshell had landed in the midst of the conference, declaring apartheid was a false gospel, a false ideology, and calling upon Christians in South Africa to reject it unequivocally.

This declaration has been compared with the likes of the Barmen Declaration in Germany, but it had two very important differences. The one was that it was not made up of six theses; it was eight pages long, and took about three quarters of an hour to read. And the second one was that it was clearly a political document in a way that the Barmen Declaration was not in any direct sense. At that stage I was quite deeply involved and in the process of making a decision whether to join the CI staff or the SACC staff. Finally I moved in the direction of the SACC, not least because my church asked me to do so. So, I moved into Dunwell House, a building opposite Diakonia House, where we eventually moved together with the CI.

Dunwell House, in Braamfontein, was a remarkable place. It housed the offices of the CI, the SACC, as well as those of the Black Consciousness Movement black theology project. And when you moved into that environment you moved into an amazing network of people and of daily events. It was a hum of activity. We were rubbing shoulders day by day with about 25 to 30 people on the staff of these various organizations. At the centre of it all was Beyers Naudé, the great enabler, who would draw you into his office and consult with you, even if you were a junior person. He'd want to know, "What do you think about this?" - he was remarkable at doing that. Whether he followed up what you thought, or what he thought, I'm not too sure. But he certainly was a great listener.

\section{Three themes on Beyers Naudé as a public theologian}

I now want to pick up three themes very briefly. First of all on Beyers as an ecumenical public theologian. Secondly, he was a confessing public theologian. And thirdly, he was a public theologian in solidarity with the other.

\subsection{Beyers Naudé as ecumenical public theologian}

Dr Nash has given us a wonderful kaleidoscope of the ecumenical context within which Beyers was nurtured and in which he functioned. In the 1960s, when he was explaining the Bible Study Movement, which laid the foundation for the CI, Beyers said: "Without the united church or the united standing of the Christian community there was no possibility of making any impact on the world with regard to our message or our mission. It was the mission of the whole church to the whole world, not of one church to a small number of people around them. The church had to look at the needs of the world and say: If we are truly the people of God proclaiming the gospel of salvation and liberation, the transforming of human beings in society, then the church has to be one." 
In Beyers's development as a public theologian the first move was a move from simply being a Dutch Reformed theologian to becoming an ecumenical one. The critical turning point was, of course, Cottesloe, and that was an ecumenical event. Beyers became the heart and soul of what Cottesloe was all about. And he became that for the very reason that here was a person coming out of a very noble pedigree within Afrikanerdom, the Broederbond and the Dutch Reformed Church. It was quite easy for the English-speaking church leaders who were at Cottesloe to affirm what was in the Cottesloe Declaration. It wasn't a radical document. Chief Albert Luthuli and ZK Matthews were there, representing the black perspective on things. They wanted to move it much further than it actually went. For Beyers and the Dutch Reformed Church, however, it was a very significant move away from giving support to apartheid. And, it should be remembered, a draft of the Cottesloe Declaration had been prepared before the Cottesloe meeting by the Dutch Reformed delegates, and largely by Beyers Naudé.

Beyers realized that this was the way to go; we had to go ecumenically. We could no longer deal with the issues facing us in South Africa within our denominational structures. He, therefore, became more and more involved in the ecumenical movement: the World Council of Churches, the Reformed Ecumenical Synod, the World Alliance of Reformed Churches, etc. But even more than that, I think, within South Africa, he kept on trying to make links. Archbishop Hurley later wrote an article about Beyers in which he calls him Calvinist and Catholic. And I think that just about sums up what I'm trying to say here. He was a Reformed theologian to his fingertips; he was Catholic in his breadth, in his commitment, in his vision, and in what he was doing. This was, of course, anathema to the leadership of the Dutch Reformed Church at that time, the fact that he was a person who was so open to people of other traditions and other denominations, including Roman Catholics, who were joining the Bible Study groups that he had started, and who were encouraged to do so in light of the developments at the Second Vatican Council. So here we have Beyers's major move as a public theologian, from the Dutch Reformed to the Ecumenical Church.

\subsection{Beyers Naudé as a confessing public theologian}

The second theme that I would like to mention briefly is that of Beyers as a confessing public theologian. If the first shift in his understanding of being a theologian in the public arena - and he was in the public arena right from the word go - it was as a confessing public theologian. And here I want to suggest the shift is from a confessional theologian to a confessing one - and there is a very important difference in those two words. Again I quote from an article he wrote in Pro Veritate in 1965. He wrote several articles on the question of whether or not the time had come for a confessing church in South Africa. And he wrote the following in the July issue of that year: 


\begin{abstract}
"It should be clear to anyone who is familiar with the development of the church situation and the Third German Reich and looking at the events in our country affecting the church and the state that there are more and more parallels between Nazi Germany and present-day South Africa. If I think about all these signs, then it is clear that the time has arrived for a confessing church in South Africa."
\end{abstract}

His study tour of Germany in 1953 had a remarkable impact upon him, because it was the first time that he really encountered the story of the confessing church, the Barmen Declaration and Dietrich Bonhoeffer's writings. I think this impact must have hibernated until after Sharpeville, and then at Cottesloe it came back to him with a vengeance as he began to think very clearly and decisively about a confessing church movement in South Africa. Not a new church, not a new denomination - that was not what he had in mind at all. He was contemplating a confessing church movement that would bring together people of all denominations who would become a powerful movement similar to the confessing church in Germany.

Now I've already mentioned that Beyers was a Reformed theologian to his fingertips, and when he was a student here at Stellenbosch he would have been and he was - very well versed in the confessions of the Reformed church. I remember once being here in 1957, at the time of the 100th anniversary of the Dutch Reformed Kweekskool, the Seminary, as an invited guest as a student leader from Rhodes. We all lined up outside this building and marched to the Dutch Reformed church just across the road. The preacher that day was Professor Keet. He was professor of Systematic Theology here at the time, and he was one of the formative theologians who affected Beyers Naudé for good during his studies at Stellenbosch. He was a remarkable man, Professor Keet, one of the first Dutch Reformed theologians to really come out publicly with a critique of apartheid. I remember he spoke for about an hour and a half about the Reformed Church's theological legacy, on that occasion. It was a tour de force covering the whole terrain. But what also remains vivid in my mind is that on that day there were about sixty newly-trained proponente (candidates for ministry) of the Dutch Reformed Church who had all been through Kweekskool. They stood there looking very smart in their black suits and white ties. And they were asked to confess their faith in terms of the Confessions of the Reformed Church in order to be licensed. This was a great moment in their lives and in the life of the Seminary. I was rather overwhelmed by this moment, when they confessed their faith in terms of, amongst others, the Heidelberg Catechism, the Synod of Dordt - I had to go back to find out what these were. Beyers had, of course, gone through a similar ceremony. That was part of becoming a confessional theologian. But now he had shifted to becoming a confessing one. This meant that you publicly said what was meant in terms of the issues of the day. And he learnt part of that from Keet; and the 
situation in Germany; and he expressed it in his writings in Pro Veritate at that time.

And then there was that rather remarkable sermon that he preached in the Aasvoëlkop congregation in Johannesburg where he had been the minister. It was a very large, very plush Dutch Reformed Church, a wonderful big building that he had been instrumental in building, where the leadership of Afrikanerdom in Johannesburg worshipped and where the leader of the Broederbond was a member. He preached his farewell sermon in September 1963 just before he started full-time as the director of the Christian Institute. And his text was from Acts 5:29: "We must obey God rather than man." 4 It was a very powerful sermon, even when one reads it today. What he said in that sermon expressed the change that was taking place in his life. He said: "Many people have said to me, now is not the time to speak out. We must work behind the scenes and we must talk to the government in private." But then Beyers said, this is the time to speak out; and we must obey God rather than man. It must have been an electric moment for that congregation when that sermon was preached.

Beyers was a true patriot. There is a false patriotism which is simply saying yes, yes, yes to everything that the government does, and there is a true patriotism which seeks to do what is right for the sake of the nation. And the latter is precisely what Beyers did at that point. He did not change from being a patriot to being unpatriotic; he changed from being a false to becoming a true patriot. And I think in that he was influenced by Dietrich Bonhoeffer.

I also just want to say one thing about SPROCAS, the Study Project of Christianity in Apartheid Society, which grew out of the Message to the People of South Africa to which I referred to earlier. There were six commissions around the country, comprising of about one-hundred-and-thirty high-powered people from all walks of life, academics, a lot of public figures and others. What brought them together around the Message was Beyers's vision of what South Africa could become. Because the Message said apartheid is a false gospel, we must now work for reconciliation. But I remember him saying on several occasions at meetings that we had in his office: it is no good us simply saying "that", we have got to work out what "that" means in the public arena. Because government can simply say to us: "Alright, you say that what we're doing is wrong, well, what should we do? You say the that gospel we believe is false, and that yours is true, well, put some nuts and bolts to that gospel of yours. Let's see how it would work in education, let's see how it would work in social structures, in health policy, let's see how it would work in the line of the church, in economics, law, and so forth." And so Beyers set up these commissions through SPROCAS and each one of them was to look at a particular aspect of public and social life in terms of the Gospel. Many of the

4 See also pages 25-29 of this publication for the complete sermon - ed. 
people who became involved in those commissions later became important and influential political figures - Frederick Van Zyl Slabbert was one of them, but there were lots of others. This is where they cut their teeth in terms of the reshaping of South Africa and the future.

There are two other things that I should also mention in connection with the shift from being a confessional to a confessing theologian, one who, therefore, addressed the public issues as a confessing theologian who did not simply repeat the confessions of faith but confessed them publicly. The first was the visit of a very prominent Dutch theologian called Johannes Vercuyl in 1970. He was a wonderful man. He was a missionary from Indonesia, who had gone back to the Netherlands where he met Oom Bey and was impressed by him. He began to strengthen the support base for the Christian Institute in Holland.

Johannes Vercuyl was a fairly conservative theological figure, whose confessional credentials nobody could question. And Beyers, who was a genius at getting the right person at the right time in the right place, invited Johannes Vercuyl to visit South Africa. And even the South African government, which was very good at that time at refusing visas to people whom they didn't want, could not refuse Vercuyl without losing face within the Reformed Church worldwide. He met with Dominee Koot Vorster and with the rest of the DRC hierarchy. Then Vercuyl had a debate on radio with two or three leaders, including Dr Gericke, of the Dutch Reformed Church at that time. I remember listening to that radio debate. I had met Vercuyl in our Braamfontein offices. We had spent some time there talking. About the debate: I cannot remember the details, but I do remember the DRC participants accusing Vercuyl of being a communist, which was just so completely out of court, so unthinkable that Vercuyl did not know how to answer the accusation. That was, however, exactly what the Christian Institute was labelled as by this stage; it was "communist" and people who supported it were likewise. Even those with very strong Reformed credentials, like Vercuyl, were now all rejected along with Beyers Naudé.

The second thing I want to mention here, in connection with Beyers's shift from confessional to confessing theologian, is a public discussion he had with the German theologian Dorothea Sölle in 1986. Oom Bey and Sölle were discussing the peace movement, liberation, environment, issues of that kind. In 1986 these were major issues in Europe and around the globe. Right at the end of this discussion Beyers asked Dorothea a question: do we not now need a new confessing church around the questions of liberation, environment and peace? This notion of a confessing church that would confess faith publicly around these issues remained with him throughout. 


\subsection{Beyers Naudé the public theologian in solidarity with the other}

Finally, in this last shift in the career of Beyers Naudé, I would like to say something on his shift from white to black. The first shift was from Dutch Reformed to ecumenical, the second was from confessional to confessing theologian. Then the third was from white to black. Here one could mention many things, which we do not have time for. I am not going to read the statement which he gave in court during his trial in 1973, but by that time he was making it very clear that there is no reconciliation possible in South Africa without justice. And that there is no way to understand what justice means without doing precisely what the previous speaker was saying to us earlier: getting alongside the people who are suffering.

The important things that moved Beyers towards the above had started long before this period in the history of the Christian Institute. But the Programme to Combat Racism and the Mindolo Consultation that lay behind that were very important ecumenical moments, especially the former. I remember we had in the offices the speech of Martin Luther King Jr - I think it was the one "I have a dream". It was banned in South Africa, but we made recordings of it and we put them in inconspicuous plain covers. This speech then circulated around the country because Beyers was captivated by Martin Luther King as he had been by Dietrich Bonhoeffer. Now also by black theology, which had emerged as a very powerful force in the late 1960s and also had its offices right there in Dunwell House.

The notion of liberation theology, of the option for the poor, all of this was pushing Beyers to recognize that it was no good any longer to merely think of the Christian Institute, as an instrument that brought largely white, largely liberal people together to do Bible study. That was totally inadequate. This realization he had come to during the 1960s, and the Christian Institute was now more and more becoming not simply a non-racial organization, but one which was driven by the vision of solidarity with the other.

Then of course came the critical point; or rather three critical points. The first was in 1974 in Hammanskraal at a conference organised by the SACC on racism, where Beyers and Doug Bax proposed a resolution on conscientious objection, which was subsequently adopted. The reason for this was, as Beyers and Doug said at the time, we had to do something. The situation in the country, the deterioration and the violence, was such that the only way that young white Christians - and not only young ones - could signal their opposition to the militarization of South Africa, to the war that was taking place, to the violence in the townships was through conscientious objection to military service. It was a very important moment in the story of the church's struggle.

Then, in 1976, the Soweto uprising occurred: that, like Sharpeville, was another moment of truth. South Africa could never be the same after the Soweto uprising. That signalled a dramatic change and led to the death of Steve Biko, murdered by 
the security police. And it was largely because of the stand that the Christian Institute was taking on the Soweto uprising, its identification with those who were appalled by the death of Steve Biko, as well as the fact that the Christian Institute was now clearly an organization that had identified itself fully with the liberation struggle, that it was banned in 1977 and Beyers's own seven "lean years" began.

\section{Final impressions}

Let me end by referring to two things. The first is that during those seven lean years the prophet revealed again that he was a pastor at heart. I started off by talking about Beyers as the one who enabled others, this pastor of the pastors. During those seven years of his banning people made pilgrimages to his home to talk to him. And as he said at that lecture he gave at UCT on those "seven lean years" after it was over, there was no way that he could remain outside of what was happening. Even in his enforced silence Beyers spoke as pastor but also as prophet, as people came to discuss issues with him - some of which was highly confidential and politically explosive stuff. The second thing I would like to mention in closing is that I do not think that I have ever met anybody - and I'm sure this will be true for many, many others who knew him - anybody, who in the most adverse circumstances, in the most appalling times of darkness, was always full of hope and courage. You could be in a conversation in which things were so bad in terms of your prognosis of what was going on around you that you didn't know where to turn, and Beyers would come into the meeting and all of a sudden he would begin to open up possibilities. He would once again be an enabler by beginning to project a vision and to instil courage in the people who were there.

Thank you very much. 


\section{FROM THE ARCHIVES \\ THE NEED FOR POLITICAL REFORM ${ }^{1}$}

Beyers Naudé

In accepting the singular honour of dealing with a theme of such crucial importance in our country as stated in the title address, I am deeply aware of many personal shortcomings in doing justice to the subject. On the other hand, my deep concern for the future of our country leaves me no choice but to share with you and I hope with many others outside this hall - my views, insights and concerns, as well as the steps which I believe to be urgently required in order to prevent a major catastrophe in the future.

Because of the wide scope of issues included in the full title, The Need for Social and Political Reform, I was forced to concentrate mainly on the need for political reform because of the seriousness of our current political situation and because in our country, with its dangerous legal restrictions of social issues, social reform could only become operative and effective when fundamental political change has been brought about.

\section{The present political position}

The report of the SPROCAS Political Commission has dealt so clearly with the basic ethical principles which, for a Christian in any case, should underlie his political criteria and judgements, that I do not see that it could serve any useful purpose to try and repeat the contents thereof. Similarly, the different SPROCAS reports have dealt so ably and with such devastating accuracy with the harsh and bitter realities of the policy of apartheid and with the long, sad history of the breaching of ethical principles, the erosion of practically all black political rights, the removal of civil liberties and the disastrous effect this has already had and is increasingly going to have on black and white people, that I see no point in repeating what we all know - or should know: that for all practical purposes no black man in this country has any effective say or share in any of the political decisions of our country. This situation has existed for many years, even before the National Party came to power, but since 1948, it has deteriorated badly. Although political leaders of the African and Indian racial groups have tried for many years to bring about political change, the increasingly repressive actions of the Government through increased discriminatory legislation, constant bannings, harassments and intimidation by the Security Police, buttressed by a widespread system of paid informers, succeeded in crushing or suppressing temporarily and effectively all black political opposition.

1 Lecture given by Beyers Naudé on 12 June 1973 in Durban as part of a series of SPROCAS lectures. Naudé talks on the need for social and political reform. 
This situation still exists, except for the emergence of African political leadership in the African homelands - a product of the Government-sponsored agencies, which the Government cannot suppress out of fear that this might be seen as an admission of failure on the policy of separate development. But the creation of this limited form of political action in itself cannot be seen to make any appreciable difference to the lack of political rights of the black people of South Africa.

If it is claimed that our political situation today is much more serious than before, yes, even dangerous, surely this could only be the case if a number of important new factors have emerged which previously did not exist - or if they existed, did not have any definite or decisive influence on the political situation. Are there such factors or forces present today, and if so, to what degree do they contribute substantially to the situation to make the need for social and political reform more urgent than before? Or, to put it differently, to what degree have new elements or factors been introduced which make the continuation of white domination more dangerous and potentially more explosive?

I wish to mention seven factors which up till approximately three years ago were either non-existent or had very little possibility of making any worthwhile impact but which from 1970 onwards have created a situation fraught with danger for all South Africans, but especially for the whites.

1. Increasing isolation of South Africa from the outside world: during the last three years the voices from many quarters clamouring for the isolation of our country from the outside world have gained tremendous momentum. Nowhere is this more clearly discernable than in the area of sport, where we are witnessing the increasing success of a world campaign to exclude our country from all international participation in sport until such time as South Africa fully subscribes to and implements the principle of non-racial sport, clearly implying the selection of players from club level upwards solely on the basis of merit. These pressures have already been partially successful, forcing our Government to institute a system of multinational sporting events. The fact that the public of Pretoria (the city where the headquarters of a number of verkrampte movements like the HNP and Sabra are centred) responded so positively to this multiracial experiment is proof that many Afrikaners are far more open and amenable to such racial contact than the Government was prepared to admit or to give them credit for, but this will by no means diminish the pressure from the outside world on our country. The fact that a limited measure of success has already been achieved is only going to serve to increase the efforts at isolating our country until such time as we acknowledge that the choice is a simple (but for many Afrikaners an agonising) one: integration - or isolation. And if attempts at isolation could be implemented effectively in one sphere (that of sport), we should not be surprised if in other spheres, such as art, drama, cultural 
exchanges, opportunities for overseas study and participation in international cultural and academic conferences, similar efforts are going to be made.

2. Increasing economic pressures: The average white South African is to some degree aware of news reports of individual actions by certain bodies of investments, e.g. the World Council of Churches; the growing chorus of voices from international labour organisations calling upon trade unions to refuse to handle South African goods at ports of trade, e.g. the most recent I.L.O. Conference in Geneva. Not as well known is the full extent of increasing pressures being exerted upon American, British, Dutch, German and Swiss firms operating in South Africa not only to increase all black wages substantially, but to ensure that full and equal labour rights, as generally accepted throughout the Western world, would be accorded to all South African labourers regardless of race or colour. A number of firms could perhaps withstand these pressures for a shorter or longer period, but eventually the majority will be forced by world opinion and world pressures either to accede to these demands or to pull out of the country. South Africa finds itself in the fortunate position of its economic strength being determined to a much greater degree by its mineral wealth than by its industrial productivity.

Time and again, in one or more important sectors of our economy, a crisis has been averted by such events as the rise in the price of gold or the devaluation of the dollar, and because our economy has remained at this level of strength and the pressures have not yet increased substantially, the Government's position has remained fairly secure. The recent African labour strikes with their demands for a substantial increase in wages, the spiralling cost of living with the spectre of inflation already threatening the existence of all lower income groups, plus the insistent and growing demands of the whole world that South Africa should be hit where it hurts most, i.e. in the fields of trade and investment - all these are signs of a situation of potential danger which could rapidly materialize if our economy takes a wrong turn.

3. Increasing threat of terrorism and military action: It is generally accepted that there are areas of confrontation where warfare could erupt: Vietnam, the Middle East, Southern Africa. With America's withdrawal from Vietnam the attention of the whole world has been focussed much more on the other two areas. During the last three years an increasing number of government, church and private agencies have made contributions to the humanitarian needs of movements described as liberation movements by the world outside, and as terrorist organisations by the white inhabitants of Southern Africa. The difference in terminology is in itself a telling comment on the basic differences in understanding and interpretation between the white minority of southern Africa and the whole outside world. The increased threat of guerrilla and terrorist action in Rhodesia is not only drawing more and more white people 
into a common white laager of fear, but is also pushing South Africa closer and closer to a situation of armed conflict and war. Even to the uninformed white South African it should now become more evident that our country is slowly drifting - or being inexorably pushed - into a form of open warfare. I am aware of an increasing number of young whites, including married couples with families, who have either already left the country or are seriously contemplating emigration simply because they see no future for themselves and their children here.

One tragedy is that so many whites become highly emotional, angry or defensive when hearing of increased terrorist incursions in Mozambique and Rhodesia, instead of acknowledging that our racial policies are the main cause for such actions and that if South Africa were to bring about a fundamental reform tomorrow to meet the legitimate political demands of our black population, terrorist action would hold no threat for our country but would in fact be met by the rebuttal of a united front of black and white. Another tragedy is that many blacks have lost all hope that the majority of the white electorate, through a long process of ideological brainwashing, is able any longer to recognise the root causes of the emerging confrontation between black and white, namely the racial policies of our country, and thus to change the course of our history by supporting a political party which advocates a fundamental political and social reform. Thus, these whites have become the victims of their fatalism. If it is true that the majority of whites already consciously or unconsciously accepted that an armed conflict with black Africa is inevitable, then the position of the white people is even more dangerous and vulnerable than they themselves realise.

4. Growing black consciousness - and bitterness: For many years a number of white and black leaders have been voicing their concern at the continued growth of frustration, anger and bitterness in the hearts of the black people of our country against the whites because of the continued discrimination against and humiliation of people of colour. During the last three years we have seen the emergence and rapid growth of black consciousness, of black political awareness, linked to the mounting criticism of practically all the homeland leaders against the policy of separate development. Daily we sense the growth of the bitterness in the hearts of the black people; increasingly we experience the polarization between black and white and the rejection of everything and everyone seen to be white. What future hope is there of building peaceful and harmonious relations between black and white if and as long as the whites stubbornly refuse to face the many injustices they have inflicted upon the blacks and to seek to bring reform in every sphere, especially the political and social ones? 
5. South Africa's vulnerability vis-à-vis South West Africa: Up till three years ago the situation in South West Africa (Namibia for the outside world) was not seen by the majority of whites to be playing any significant role in the future of our country. The unexpected strike of the Ovambo labourers, the increased pressure of the UNO, the voice of concern and protest emanating from the black Lutheran Churches, the danger of Angola eventually becoming a base for terrorist operations against S.W.A. - all these new factors brought home, in no uncertain terms, to the whites of South West and South Africa the vulnerable position of this mandate territory and of the country governing her. It should be clear to all of us to what degree the hasty and full-scale implementation of the policy of separate development has increased the opposition and bitterness amongst the indigenous groups of people of South West and has strengthened the determination of many nations of the world not to rest until the rule of this territory is taken away from South Africa. The military weakness of the United Nations must not blind white South Africans to the potentially explosive situation which the implementation of the policy of separate development has created.

6. The present sterility in white politics: Up till three years ago there still seemed to be some form of dynamism and drive in white politics. During the last two years, it has become abundantly clear that both the National Party and the official Opposition are unable or unwilling to face the political, social and economic realities of our situation. The National Party is unable to do so - even though some leaders may be willing - because it would require a fundamental reversal of every main principle upon which the NP has based and sold its racial policy to the electorate. Moreover, in order to remain in power, it would need a much longer period to bring around its supporters to accept a policy of non-discrimination against and full potential participation by blacks than the time we have left. The United Party, in turn, is unwilling to do so because it would require taking a much bolder stand against the NP in the field of race relations - which seems a very remote possibility.

No better proof of this political deadlock could be found than the emergence of the verligte movement of a number of Afrikaans academic leaders desperately seeking ways and means of breaking this deadlock. Their task will be made more difficult by the tragic ignorance in which the Afrikaans electorate is being deliberately kept by the Afrikaans political press, the radio and the Afrikaans churches regarding many aspects of our racial situation. They will also discover the dangerous effect of widespread apathy and fear which has been created by the wilful suppression of movements for social change through the vilification, intimidation and labelling of many persons of integrity with such smear labels as "Kafferboeties", liberalists or communists. A crucial test for their concern for and commitment to change will be their willingness to take a determined stand in public in the face of similar accusations. 
In evaluating the present political impasse the following facts have to be added to complete the picture of frustration in the situation.

1.1 Only two population groups are at present determining the trend of political events in our country: the Afrikaners - and the black people. The other groups feel very strongly left out in the cold, and these two groups stand miles apart.

1.2 Political power still lies in the hands of the whites but the political initiative is rapidly passing into the hands of the blacks. For black people this is a source of joy and hope - for whites a source of fear.

1.3 At this moment in our history our country urgently needs a person of stature, integrity, charismatic leadership and political acumen who has won the trust of both black and white to such a degree that both groups would be willing to entrust their future to his hands. But where is a leader with such gifts and qualities to be found, who could lift our country out of the present political morass in which we are bogged down? And if he is found, will both groups accept him?

This leads me to refer to another situation of danger which could arise, depending on certain developments. If the UP, as official Opposition, remains as weak as it is at the present and if a crisis situation arose in race relations, either in South Africa or in South West Africa, which the Prime Minister interprets to be a serious threat to national security, I would not be at all surprised if Parliament's right to govern would be seriously curtailed or even temporarily suspended and a military regime established. The effect which such a step could have not only on black feelings but also on world opinion would be very serious indeed. Therefore, everything possible must be done to prevent such a development from taking place.

\section{Some guidelines for political reform}

In view of the potentially dangerous and explosive situation in which we find ourselves at present, as I have sketched it above, it is of the utmost importance that all South Africans who have the peaceful development of our country at heart should urgently seek practical and effective solutions in a new direction. The Political Commission of SPROCAS has come forward with a number of conclusions and recommendations which merit careful consideration. On the basis of this report I shall now try to summarize the kind of reform which I believe is needed in order to defuse the mounting tension and eventual violent confrontation, not only between South Africa and the black movements outside the country bent on overthrowing racial injustice by armed insurrection, but also between white and black within our borders. I present these thoughts as guidelines for the urgent 
consideration of all those in positions of power as well as for the ordinary citizen who is concerned about the future peace and prosperity of our country.

1. All political reform must start from the accepted premise that it has been conclusively proved that the policy of separate development as implemented from 1948 onwards has failed both in principle and practice - especially as far as the urban African, the Coloured and the Indian groups are concerned, and that a more satisfactory political policy must be devised to meet the needs and demands of the year 1973.

2. Any political and social reform, to be seen to become relevant and effective, must start with the withdrawal of all statutory forms of discrimination based on colour or race within a specified period.

3. All worthwhile political reform should be based on the principle that all the people of our country should have a just, responsible and effective share in the political decision-making processes of the country.

4. The inhabitants of the African homelands should be given the opportunity by way of a plebiscite (free from any outside control) to indicate whether they wish their homeland to become a fully independent and autonomous state like Lesotho, Swaziland, or Botswana within a specified period, or whether they prefer remaining part of South Africa. A binding promise would have to be given that whatever the outcome of the plebiscite, the South African Government would abide by it - even if it implies discarding the whole Bantustan concept.

5. One of the first and most urgent steps in the reform sought would be to encourage and create opportunities for consultation on the highest level between white and black leaders to work out in mutual agreement a course of political change which can allay the legitimate fears of the whites with regard to an eventual black majority rule, as well as ensure the full participation of blacks in the political decisions of the country. What we urgently need in our country today is not a consensus between white and white (which is nothing but a strengthening of the white laager!), nor in the first instance a consensus between South Africa and hostile African states, but a consensus between the white and black citizens of our land.

\section{An Appeal}

Because of the crisis situation in which South Africa finds itself at present, and because of the serious danger that the state of undeclared war in which we already are may unexpectedly lead to declared armed warfare against the subcontinent, I wish, with all the strength of conviction and feeling at my command, to make the following appeal: 
1. I wish to appeal to our Prime Minister to act in the same statesmanlike way as he has done following the Natal labour strikes, to tell the country that the real security of our country does not lie in a consensus of white political opinion, but of white and black opinion - and that all our efforts should in the first place be directed towards that goal.

2. I wish to appeal to the group of verligte Afrikaner academics which has expressed its deep concern about the present political sterility and apathy amongst whites to recognise that no verligte white movement has any hope of success unless it has the support of the responsible black leadership of South Africa. Today such a group will still find a positive black response to its approach - tomorrow it may be too late.

3. I wish to appeal to the leaders of commerce and industry in view of the emerging dangers of increased labour unrest and serious economic disruption, which could follow upon increased terrorist actions and trade boycotts or economic pressures, to shed the cloak of political "neutrality" behind which many have been hiding and to take the lead in bringing about the political and social reform which is so essential to ensure the peace and prosperity of our country. I would like to extend this appeal not only to the English-speaking and Jewish business community but also, and especially, to Afrikaner industrialists and business leaders like Dr Jan S. Marais, Dr Anton Rupert and Mr. Louis Luyt who, because of their financial strength, wield immense political power and who could, if they wish, make a significant and possibly decisive contribution to participate in steering a new course for our country.

4. I wish to appeal to the white clergy of our Afrikaans churches, who in some way or other have privately expressed their deep concern about the turn for the worse which human relations are taking in our country, to come into the open and to speak, as men of God, with a prophetic voice to inform and enlighten our Afrikaner people about what really is at stake. A fearless expression of common concern by a group of Afrikaans clergy could well mark a turning point in our history. Therefore my urgent and loving plea: In obedience to God, in responsibility to our Afrikaner people, in order to maintain your integrity speak and act before it is too late!

5. Lastly my appeal to the black people of our country. A small - perhaps insignificant - group of whites try to be aware and to make other whites aware of the many forms of injustice and humiliation to which all blacks are subjected. We, this small group of whites, can never fully feel what you feel, suffer what you suffer and strive for liberation as you do. Neither do we have the right to prescribe to you how you should seek to obtain your rights and to achieve your freedom. But we wish to plead with you, in the unwavering belief that the day will surely come and is already coming when your humanity will be fully recognised, your rights will be fully ensured and your people will be truly free: 
prepare yourselves and your people so well and act in such a responsible, inspired and fearless way that when the social and political reforms which we believe are so desperately and urgently needed have taken place, you will be able to lead South Africa to a new future where all forms of racial superiority, of religious bias, of social inequality and of political injustice will have been left behind. 


\section{THE POLITICAL WORSHIP OF GOD \\ THE EXAMPLE OF BEYERS NAUDé}

Prof. M Rumscheidt ${ }^{2}$

At this moment I can feel the ground under my feet moving, for even while I cannot fathom the depth of the honour of being in your midst - in this country, in this university, in the institute that bears the name of a man who honours all of us still with who he was and what he gave - I happily grasp the occasion of your invitation to join you and so many more beyond the walls of this house in a grateful celebration of one, whom to look to is, as I see it, an act of wisdom. But there is a second, different dimension to my feeling of the ground moving: is it not pure folly for a German-born Canadian, a white Euromerican (or is it Ameropean?) male to come here and speak of Beyers Naudé? And if it is not pure folly, then is it not at least a rather cheeky, tall order to ask you who knew this man, you who lived and still live in his context and its multifaceted realities, demands, its anguish, pain, hope and vision, listen to one who met him for three days only and shared his context only from afar?

But here I am and, yes, I do want to speak. After an e-mail prearrangement that my fiancée had made, four persons met at the luggage-conveyor at the Leonardo da Vinci Airport in Rome in June 2004. They were Francine and Nico Koopman, Nancy Lukens (the afore-mentioned fiancée) and me. Having gathered our suitcases, we waited outside for a taxi to take us to our conference centre, the Casa LaSalle of the Christian Brothers Community, to attend the IX ${ }^{\text {th }}$ International Dietrich Bonhoeffer Congress. It turned out that our taxi-driver was not licensed to pick up passengers at the airport. We waited for him nonetheless and while doing so, Nico Koopman told us of a recent conference here at Stellenbosch University focussed on Beyers Naudé on the occasion of his $89^{\text {th }}$ birthday. Plans were developing, Nico told us, for a similar celebration cum conference for his $90^{\text {th }}$ birthday in 2005. I heard Professor Koopman say to me, "You should come and present a paper." I confess that at that moment I felt like a little dog that has just been given a stick to hold between his teeth and that then, of course, refuses to let go of it again. So, that little dog, even greyer than a year ago, is here not ready to let go of his stick, but very happy to talk among and with you in the country that has in a variety of forms drawn me for much of my life.

Let my next words now be words of great gratitude. I find it emotionally quite overwhelming to be in South Africa; it is the third time that I am here, again and

Lecture given at the Beyers Naudé Centre for Public Theology on 27 May 2005.

2 Martin Rumscheidt is emeritus professor in Systematic Theology at the University of Nova Scatia, Canada. 
again drawn to something that in ways I still try to understand, touches me in my being at the depth of significant aspects: I am a Christian, a person of the church, a theologian, a German who in all those dimensions seeks to come to grips with my native country's, my church's, my own family's twentieth-century history, now a Canadian who is working with the church there that ordained me to the ministry of word and sacrament in seeking ways of reconciliation with the native peoples we call them First Nations in Canada - whom we Europeans, we late-comers to the shores of the North American continent, treated in ways the United Nations Convention on Genocide of December 1946 defined as "genocide." I am deeply grateful to be allowed to be in your country as a willing learner from you and what you yourself are and have as persons, whose beings have dimensions like those I named as being mine. I am deeply grateful to be someone who with you bore love, respect and appreciation for the man who intersected - and still does, of course many lives, instilling courage, hope, vision, grace, patience and, toward the end of his life joined innumerable thousands here and in many parts of the world in the singing, in freedom, legally without defiant anger and angry defiance, what for me is one of the defining songs of the twentieth century: Nkosi Sikele' iAfrica. I have a photo taken in the Anglican Cathedral of Cape Town during the opening worship service of the VII International Bonhoeffer Congress, of Beyers Naudé with a choir of women and men from Gugulethu Township (I believe) leading the gathered people in the singing of that song. I saw no one around me from Europe and North America who did not have tears running down our cheeks at that moment. The ground did move under our feet.

A few days later, Mr. Carl Niehaus, then working in a responsible position in the new government of South Africa, arranged for a visit to Robben Island. When we had completed our visit to the prison, had stood in the cell of Nelson Mandela and, in a kind of veneration, before the trees he had planted and nurtured in the exercise yard, Beyers Naudé spoke to us. It was not only that again the ground moved under our feet but also - so it felt to me - that the sun stood still to listen. We heard the compelling voice of a human being whose integrity brought healing, whose voice rang true. There is a saying I learned in the United States that goes somewhat like this: "Sound so is like a perfect bell, no matter where you strike it, it gives out the same, perfect and clear tone." That image I want to use for this man: his words ring out, calling, consoling, cajoling. And since most belfries have several bells, it is only proper to say that the bell, Beyers Naudé, had next to him other equally true, clear, perfectly tuned bells, voices that together made a gladsome sound in the rainbow-people country.

The night before the Congress concluded, three people joined Oom Bey (that is how the chair of the session, Professor John de Gruchy, called him). The other two were Archbishop Desmond Tutu and Ilse Naudé. The four had a free-flowing conversation about their beloved country. Apparently South African television had heard about the event and came to record it. In earlier days it would not have been 
possible for such a remarkable gathering and public exchange. Listening that evening, I learned how true Hlophe Bam's words are: “Whenever people are paying a compliment to a famous man they always say, Behind every successful man there is a woman." I would much rather say, "Beside every successful man there is a woman." 3 Observing those four persons, taking in their animated exchange and paying attention to their theological convictions and the strength of their faith, not only poignantly confirmed the Psalmist's utterance, "How good and pleasant it is when brothers [and sisters] dwell in unity," (Ps 133:1, RSV) but also magnificently demonstrated the depth of the biblical assertion that it is our human maleness and femaleness together and, analogous to the inner-Trinitarian relationship, the mutuality and togetherness of woman and man that is the image of God in which we were created. I saw that image as I looked at Tannie Ilse and Oom Bey.

I think that you see not only that, but also how I have been touched by the personalities of Ilse and Beyers Naudé, that an emotional impact on me is there from them to this day - I am telling you this as part of describing to you how I approach my topic. I need to be somewhat, albeit briefly, autobiographical.

I grew up in a family deeply committed to the church; it was part of my parents' strong and good piety to hold regular family devotions with hymns, Scripture readings, prayers. I am shaped by that tradition. I was born during the reign of Hitler and National Socialism. Father was an executive member of the industrial conglomeration called I.G. Farben. His assignments brought him in touch with the use in industry of slave labour and the associated policies, jointly applied by I.G. Farben and the SS, of "Vernichtung durch Arbeit," extermination through work. I have no evidence that Father himself ever ordered such policy application or participated personally in the selections that determined who was able or not to continue working. Some years after the end of World War II, we moved to Switzerland; it was an "industrial transfer" like our subsequent move to Canada in 1952. It was there that I first met Jewish persons. My childhood years were indeed "judenfrei." Gradually I began to ask questions; it was only after my year of study with Karl Barth in Basel from 1961 to 1962 that my questions took on real insight and urgency. Barth had called my attention to Helmut Gollwitzer and Martin Stöhr. Influenced by their theologies and, subsequently by them personally, I learned to deal with my parents' but especially Father's refusal openly to address the history of and around the Holocaust, beyond the declaration that they did not know. How to square that refusal to enter into the kind of reflection one would have expected to arise naturally from the personal piety and faith that marked our whole family's life? I was fortunate to have a partner-in-marriage who with her own openness to matters of politics, of justice and peace, and with her love for me

3 Charles Villa-Vicencio and Carl Niehaus, (eds.). 1995. Many Cultures, One Nation. Festschrift for Beyers Naudé. Cape Town, Johannesburg, Pretoria: Human and Rousseau (Pty) Ltd. p.38. 
sustained my ongoing exploration of the past that marked my country, my church and the theology living in my mother's and father's Christian faith. In the 1970s, Barbara, my late wife, asked me to join her in a demonstration outside a liquor store in the Nova Scotian town of Halifax, where we were then living. The demonstration was about getting South African wines removed from sale. Among those wines was a particular brand of sherry my father kept on buying until Canada finally stopped importing it and all other South African products. Part of our demonstration was a black student from Kenya, attending Dalhousie University. He was dressed in a Santa Claus suit, with a long white beard. From his black face and sparkling eyes came the invitation to everyone entering that store not to buy South African vintages. It was quite the image: a black Santa Claus in our white town telling us what not to do! From that day forward my work on the Holocaust was influenced by what I then began to know about apartheid and vice versa. Here, in that interlinkage, faith and politics or, as Karl Barth put it in his Gifford Lectures of 1937: "the political worship of God," became bound firmly together for me. (As an aside, why the English translators J.L.M. Haire and Ian Henderson rendered the title of Barth's 19th lecture in that series, in German “Der politische Gottesdienst" as "The state's service of God," is more than obscure to me, except perhaps that they preferred not to be so direct in 1938.)

It was in the course of WWI that Karl Barth found what he called "the strange, new world in the Bible." Among the "strange" or "new" things he discovered, impacted by the wretched supportive embrace and welcome of that war in 1914 by religious and secular persons and institutions alike throughout Europe, was a God who does not tolerate being used as a tool to bless human affairs. One can trace his conversion to that "strange, new" God in his first and, in my view, still breathtaking book The Epistle to the Romans (first edition, 1919). Here Barth develops his opposition to the way Neo-Protestantism had spoken of God in the nineteenth century, the theology, I believe, which had also shaped the teachers who then taught Beyers Naudé. In its own masterful way that theology spoke of "god" as an entity that stood for something humans could use to legitimate what they already had in mind and planned to proceed with. In such language God was just good enough for us humans to accomplish and crown what we initiated on our own. But "on our own" meant what we humans had begun without God. And, so Barth concluded, for that reason the entity used to accomplish and crown our actually godless undertakings - such as a war - was a non-deity, no matter how solemnly we affirmed that this insight about God was not derived from ourselves. Barth counters that we speak of the God who truly is God only when we take seriously that what God is about is exclusively God's concern. That concern resists being used for purposes determined by humans. The task of theology, its proper task, does not therefore derive its meaning from yielding use for human undertakings - such as war, cultural, economic or male domination, apartheid - by making them plausible (and saleable) through a religious underpinning. According 
to Barth, the proper task of theology is to discern God's own concern and then to serve it. Theology does this by always becoming converted in its thinking and by understanding that it is not God who is to serve our plans and ideas, but that it is humans who need to become servants of what God is concerned with.

Karl Barth made a clear and, I would say, decisive theological response to the political events of 30 January, 1933 in Germany, Hitler's accession to power. Comparable in several aspects to the accession to power of the National Party in this country and its imposition of the policies of apartheid, Hitler's policies were welcomed by Germany's churches and given theological, even biblical, underpinning. Barth responded by saying that only a theology that has gone utterly astray would give such support. He published the now famous pamphlet Theologische Existenz heute in June of that year in which, close to the beginning, he made the often badly misunderstood statement that, today more than ever, the issue is "to do theology and nothing but theology, as if nothing had happened." And do that "like the chanting of the hours by the Benedictines in the nearby monastery of Maria Laach, which goes on, undoubtedly without break or interruption, pursuing the even tenor of its way, even in the Third Reich."

How unpolitical that sounds! 4 But it actually is the foundation for what Barth called "the political worship of God." For whenever something like Hitler's rise to power happens, or now by extension, the assumption of power - even when that happens through "democratic" elections - of a government of apartheid, theology must not allow itself to be moved and revert back to placing God at the disposition of what to humans appears justified and helpful in such an event. That needs to be taken seriously in face of such situations, unconfused, as if nothing had happened. Other factors, even the most pressing ones, must not dictate what church and theology must do, for only God declares what their task is. Were they to let themselves be interrupted and distracted by such factors, the God to whom they appeal would be subjected to the critique of being a non-deity. Here Barth astutely links the theological substance of the First Commandment: "I am the Lord, your God, who brought you out of slavery in the land of Egypt. You are to have no other gods beside me," with the ethical imperative of the Apostles' assertion: "We must obey God more than human beings." And that is why the seemingly harmless statement became a biting affront to those who took Hitler's coming to be a new hour of God, a new kairos. Barth's reply to the question on the lips of so many Christians - What does this hour, this kairos, signify for Christianity? - was the radical word: Nothing! That hour of National Socialism or, again by extension, of the National Party here, has nothing at all to tell us about what we as Christians

4 In what follows, I base my reflection on the excellent examination of Barth's pamphlet by Eberhard Busch, "Doing theology as if nothing had happened" - The freedom of theology and the question of its involvement in politics," in Studies in Religion/Sciences religieuses, Vol. 16, No. 4, Fall 1987, pp. $459-471$. 
must or must not do. Barth's statement is, as well, a spiritual put-down reminiscent of the scorn Elijah heaped on the idols on Mount Carmel and on their hordes of functionaries. And in the face of the growing authority of a totalitarian state, the assertion that for Christianity nothing had happened at all is a rather bold and highly political stance to take. Such an assertion is by its very nature highly critical of churches and theologies whose theological statements are dictated by a particular political judgment and are subsequently used to legitimate that judgment or to identify it with God's concern.

Barth's critique in that 1933 pamphlet was not directed so much at the political system of the day as at the Christian churches' affirmation of it. That is why he did not counter those affirmations with a different political judgment, similar in kind but not in substance to that given by the churches to Hitler or, again by extension, to the apartheid regime. Instead he emphasized that his own judgment of Hitler which he did not deny having - had nothing to do with his theological task which, being the task of theology, was determined and bound solely by Scripture and the confessional statements of the Evangelical Church. It follows that Barth could offer a credible critique of National Socialism only if he resisted crowning his own, however different, political judgment with theological dignity. Barth's analysis of the German Christians' claim that their support of Hitler had theological justification is that their political enthusiasm for Hitler was rooted in a deep theological error, namely that their political judgment had been formed independently of God's Word and then wedded to a theological interpretation, giving rise to a marriage in which the political judgment dictated to theology what to say. The hearing of God's claim rules out in principle the simultaneous hearing of another claim: "You are to have no other gods beside me," says the commandment; "we must hear and obey God's claim more than the claims of humans."

It is in this sense that Barth went on the attack in 1933, although his attack was not aimed directly at the political system, but rather at the combination of the task given to the church with a "Yes" to that system. Indirectly it was very much a matter of taking a political stance. The Gestapo headquarters in Berlin understood it precisely as such; a memorandum of May 1934 noted that "Barth's position must be regarded as a real danger. In his theology he creates enclaves that allow people to isolate themselves against and from the demands of the new state for religious reasons." Thus, in 1935 the Nazi authorities banned him from Germany and his position there back to his native Switzerland.

If that is what taking an indirect political stance means, then one understands that "indirect" does indeed not require others to guess what is implied; instead what had been spoken followed from listening to God's Word in the testimony of the Bible. Barth's sermons of 1933 were "political preaching" in that he spoke out for Jews, not because he felt like doing so, but because he had to on the basis of the 
biblical text itself. And thus they became the strongest imaginable word(s) of solidarity with the already then badly mistrusted Jews. In a later writing, "The Christian Community and the Civil Community" (1946) he writes that wherever Christians cooperate with others in the political sphere they ought not to call themselves Christians but ought to act like Christians, anonymously, so to speak, and translate their reasons into arguments everyone can understand. And, I would add, as such they render political worship of God.

This form of theological reflection became for me the "lens" through or with which I began to look at the testimony, the words and actions, indeed the personal "fate" of Christiaan Frederick Beyers Naudé after my close theological companions and friends Martin Stöhr and Dorothee Sölle drew my attention to this, as they called him, authentic voice in South Africa. - I can still see Dorothee Sölle, standing at the base of a monument in the town of Barmen in 1984, during a large, several-dayslong commemoration of the important "Barmen Confession" of 1934, and hear her mentioning the name of a man, still banned since 1977, for his opposition to the apartheid rulers of South Africa, Beyers Naudé. We had left our Barmen conference halls to go out to protest the imminent visit to West Germany and Helmuth Kohl of Prime Minister P.W. Botha. Martin Stöhr, speaking with me a year or so later about the then new "Kairos Document" of which Naudé was a signatory, said: The Kairos Document is developmental aid - in matters of Christian witness - from the South for us in the North. It demonstrates, according to Martin Stöhr, that and how the New Testament - and through it, the Christian Church - takes the gospel of the First Commandment from and with the Hebrew Bible (the so-called Old Testament) when it declares (Acts 8:29) that we must obey God more than humans. He then told me that that had been the text of Beyers Naudé's sermon bidding farewell in 1963 to his congregation at Aasvoëlkop. I would like to characterize that sermon and his subsequent Christian witness in the words a recent interpreter of Karl Barth used for Barth's witness: "Preferably unpleasantly noisy than pleasantly quiet" (Frank Jehle, Ever Against the Stream, Wm. B. Eerdmans, 2002). Two significant dimensions of faith were reaffirmed and demonstrated in Naudé's witness, as I have come to see it. He mentioned the profoundly undemocratic attitude that "politics is a matter for politicians only; politics is a dirty business". Against that he set the necessity that one should learn that the Christian faith and democracy have one thing in common, namely that both accept that all people are not only responsible for leading their own lives, but are also capable of doing so, too - a direct repudiation of apartheid (as it had been, of course, of Nazism). The second dimension is this. Naudé challenged the belief that one should not expect the Bible to provide answers to political, economic and social problems and, therefore, should not even look for them there. He challenged the belief that salvation, liberation or justice dealt only with the relationships between God and humans and their innermost life or, perhaps even only with, the hereafter. What the Italian chemist Primo Levi once noted from the underground 
resistance in Turin against the Nazis I see mirrored in Beyers Naudé's testimony. Levi wrote, "We met in the Talmud-Torah school and taught each other how to find justice and injustice and the power that overcomes injustice in the Bible." In the not dissimilar resistance against apartheid, Naudé saw that and how clearly the Bible gives incentives to action, clarity of vision to distinguish between justice and injustice, and the strength to work for that justice, the human right that is of God.

There is an insightful story told of Martin Niemöller that depicts for me the nuanced theological shift from an inwardized, private relationship to God and a preoccupation with investment credits for the hereafter to what I call the broader, contextual substance of political worship of God. After Niemöller was liberated from a concentration camp he declared that he no longer wanted to preach: "How do I find a merciful God?" That was, of course, Martin Luther's question on his way into the monastery. But in Protestantism it had often become the egotistical question regarding only the personal salvation of a person, of her or his personal relationship to the Saviour. Instead, Niemöller resolved to preach for the rest of his life on the question: "How do I get a merciful neighbour?" In it resides the more direct, "Whose neighbour am I?" than the more detached one, "Who is my neighbour?" That question allows for discussion, for assessing, for more "information seeking" which lets one postpone the decision for or against action, for inclusion or exclusion.

More importantly, in our context today, is the next question that forces itself upon Christians when they let themselves be grasped by the demands imposed by the question: "But whose neighbour am I?" In that remarkable conversation, broadcast by the Dutch ecumenical broadcasting company, IKON Television, on 20 June, 1985, between Beyers Naudé and Dorothee Sölle, interviewed by Professor Dr Lammert Leetouwer, ${ }^{5}$ Beyers Naudé phrased that question himself, with - I suspect - deep anguish. "I constantly ask myself, how is it possible that a community, claiming to be devoutly Christian, building its whole life - or claiming to build its life, and also its political structure - on the recognition of God's sovereignty as it is stated in our constitution; how is it possible that we could, for instance, remove forcibly three and a half million people from their land, from where they live, from where they had settled down, from where they are happy as a community, force them into arid, remote areas where the possibility of livelihood, of income, of existence is in fact so small that for all practical purposes it is a slow process of death which they are facing? . . . And you know, I must feel the agony of this because I know that the people who are in control and in power doing this, these are my people. I cannot deny that I am an Afrikaner. I don't want to deny it. How can I? I am nothing else but an Afrikaner, and yet in that sense I don't see myself to be there - then the agony of that separation. What are the basic roots, what are the

5 C.F. Beyers Naudé and Dorothee Sölle, Hope for Faith. A Conversation. Grand Rapids and Geneva: Wm. B. Eerdmans and WCC Publications, 1986. 
deepest roots of such an injustice, of such inhumanity? How do we continue to justify it, and that in the face of the fact that the whole world outside is turning like South Africa? This is wrong, this is inhuman, and this is evil. I am still struggling because I find certain answers but yet I sense here in myself this is not yet the full answer. There is some deeper perspective of human existence, of human justification of such acts which I have not yet been able to discover" (9-10).

Oh, how those words resonate with me, a child of Nazi Germany, struggling with that past that is not over, a member of a nation that gave birth to people who profoundly enriched the culture of the Western world (and not only of the West), a person in and of the Christian church! How the probing of this honest man of your country - honest to himself, to his fellow-citizens, to his communities of faith and, perhaps most of all, honest to God - paying the price of such honesty, how his probing teaches, illumines and, indeed, liberates me - from a self-focussed, introspective guilt, from the easier, but finally imprisoning assertions of not having known what really went on, liberating for the joy of repentance, of mourning, of new and true solidarity and, as a result, or at the very heart of these, of the gift of new and glad worship of God!

At the basis of what I call "the political worship of God", ours itself, of course, only as a gift of the Holy Spirit, is what I learned from several of my significant theological teachers, is that in situations of crisis, the last thing that is demanded of us Christians is neutrality. Sometimes I have the sense that the old adage applied to the theological reflections of Karl Barth, especially in his early years, that it was a "theology of crisis," is misplaced when it is taken to mean that he responded to a crisis in theology. But it might be accurate if it means to signal that he created a crisis in theology by abandoning neutrality, by taking sides - to be specific: the side of victims. Naudé identifies this point for me when - again in the TV interview referred to - he said: "There is no neutrality possible, or no true neutrality, in a situation of crisis and I think one of the major problems of the church is that it was in a certain sense educated to see itself as a neutral body [liberal theology at its height!]. We have ... misunderstood the concept of reconciliation so that the church, or many parts of the church leadership, believes that you can only truly be a reconciling agent if you remain neutral, and that's not possible" (27).

The abandonment of neutrality as something not only of the bene esse of the church, but, instead, of its esse, and the concomitant commitment in word and act in solidarity with the excluded, is a decisive hallmark of the political worship of God. What Karl Barth eventually termed "the political worship of God" (der politische Gottesdienst) in his Gifford Lectures of 1937 grew from his activities as an organizer of labour unions in his Sofenwil parish, and his opposition to the defaming of Jews by the Nazi regime. Concurrently with Dietrich Bonhoeffer, he stood up for Jews by insisting in his sermons of very early 1933 that the church now had to preach that Jesus was a Jew. Solidarity with and advocacy for those whom a state targets 
for "exclusion" is political per se precisely because the God of Abraham and Sarah, of Rebecca and Isaac, Rachel and Israel, the God of the Son of David, Jesus of Nazareth, is the God who takes sides - that of the excluded through whom, in the form of the call to justice, God calls the excluders back into community. And if I understand the Bible, especially the Bible that Jesus knew and preached, at all correctly, that is the most authentic form of the call that this God issues. It is the shape of what Germans call "der Anspruch Gottes" (the claim of God) that holds in it the very "Zuspruch Gottes", the promise of God's grace and mercy. In my view, that is exactly what Beyers Naudé began to grasp and to live out as his witness after the Sharpville massacre and solidified through Cottesloe, his farewell sermon to the Aasvoëlkop congregation, into the Christian Institute and right into his banning.

At the end of the interview in June 1985 - now nearly 20 years ago - Beyers Naudé asked Dorothee Sölle - may both rest in peace - "Do you, in yourself, have the strength to endure whatever may come to you by way of disappointment, by way of rejection, by way of non-recognition, by way of waiting, perhaps your whole life, without being able to participate in the outcry of the truth that you are standing for? Do you believe that you will be able to sustain yourself through those years up to the very end?" In place of Dorothee Sölle's answer, I will provide one myself - I referred to it already. By the always astonishing, surprising and amazing grace of God, Beyers Naudé led us international participants in the Seventh International Dietrich Bonhoeffer Congress in Cape Town in 1996 with his own black and white, coloured and Indian co-patriots in the singing of what I often consider perhaps the most glorious hymn of the twentieth century: Nkosi Sikelel' iAfrica. God had granted this servant the experience of hope fulfilled. But immediately Naudé went back to work: to help shape this - in Archbishop Tutu's words - "rainbow" nation. And I see that aspect of Christiaan Frederick Beyers Naudé's work as the direct continuation, albeit in a new form, of his earlier political worship of God.

To this teacher, mentor, companion and saint, to this fellow Christian whom you, his people, gave to us, I, gratefully, humbly, but also deeply honoured, pay my unending respect and with you, gratefully, give praise to God. If I am allowed to do this, let me join you in saying in the words of his mother tongue: "Baie dankie, Oom Bey!" 


\section{FROM THE ARCHIVES \\ CHRISTIAN INVOLVEMENT IN THE STRUGGLE FOR HUMAN RIGHTS AND JUSTICE ${ }^{1}$}

Beyers Naudé

Man's search for truth is a long and tortuous one and the discovery thereof has usually been perceived by much agony and struggle of mind, body and spirit. In fact, when looking at history, it seems such discovery and expression of truth is inseparable from a measure of sacrifices, greater or smaller, according to the nature and duration of the struggle. It is also true to state that many times the forces of religion, including the Christian religion, viewed with alarm efforts to discover truth and even played a leading role in opposing and resisting such efforts, claiming that they would seriously threaten the traditional religious or doctrinal beliefs which were currently held. This viewpoint portrayed the lack of awareness that no power on earth can permanently prevent the discovery and advancement of truth. Another fact which leaders of Christian churches failed many times to realize was that the message of the Christian faith as presented through the Old and New Testaments contains within itself the seed of the most powerful force for the renewal and transformation of human life and human society imaginable.

The absence of this understanding and awareness has been one of the main reasons why, in the long struggle of the human race to establish and ensure human rights, the institutional church has time and again failed to become involved in such struggles - or if it eventually did, many times only belatedly. It would also be true to state - and I say this with deep regret - that in a number of instances the Christian Church actively sided with the ecclesiastical, political, social or economic status quo, and even went further by actively opposing and rejecting the efforts of those who were deeply concerned to achieve social justice and full human rights for oppressed individuals and communities. Examples abound where the Church initiated, blessed, and supported forms of warfare it regarded as justified violence in the defence of honourable causes: where the Church gathered material riches in abundance and excess for itself amidst abject poverty, hunger, and distress: where the Church remained silent at organized as well as unorganized forms of oppression of millions of people: where the Church either approved, supported, or compromised itself through its silence in protesting and acting against inhuman systems such as slavery. It is equally true, however, that from the ranks of this same institution has emerged a continuous stream of individuals and groups which, over a long stretch of time, have become involved in the struggle for human

1 Reply by Beyers Naudé in response to the Reinhold Niebuhr Award. (Originally published in Pro Veritate, January 1975 p. 4-6.) 
rights in a spirit of courage, perseverance, and sacrifice which has astounded many, which has given hope to millions, and brought about fundamental and lasting reform.

How does one account for this strange phenomenon of conflicting forces within the same body, where the official institution seems unwilling or incapable of facing the challenge of political and social justice, whilst at the same time giving birth to powerful forces and movements which create the very challenge which the Church itself is afraid or unable to face? There are many reasons which could be given for this historic phenomenon: I only wish to advance the following two which seem to me to be relevant to our concern for human rights in the world today:

1. The first is the lack of understanding of the Biblical concept of man as created in the image of God. For many centuries the institutionalized Church was unable, because of the theological interpretation it held regarding the concept of authority - the authority of God, of the Church, of the State, and of the individual - to discover the concept of man as a person created in the image of God, and endowed with inalienable rights in the sight of God. It was only when new political developments in the last decades forced nations to face the issue of fundamental human rights, especially after the Second World War, that the institutionalized Church was challenged to indicate and define its understanding. Even then, it took many decades of shocking violations of such rights in many parts of the world before church bodies started to speak out on this issue. Such expression of conviction initially was made by individual groups of Christians who found themselves living under systems of severe repression, oppression, or tyranny, and were thereby challenged to the depths of their beings. The Barmen Declaration in the time of the Nazi regime is an eminent example of such conviction when it stated:

"We reject the false doctrine, as though the State, over and beyond its special commission, should and could become the single and totalitarian order of human life, thus fulfilling the Church's vocation as well."

Another more recent and deeply moving example is the Theological Declaration of Korean Christians, 1973, which, in defining Christian responsibility under a repressive society, states as follows:

"World power is entrusted by God to civil authority to keep justice and order in human society. If any people pose themselves above the law and betray the divine mandate for justice, they are in rebellion against God."

In the same spirit a group of Christians in South Africa which refused to testify before a governmental commission of inquiry called the Schlebusch 
Commission in 1973, because of its secrecy in operations and its lack of judicial impartiality, stated as follows:

"When the Government deviates from the Gospel, the Christian is bound by his conscience to resist it, even if this results in breaking the law. It has to be done because God's will must be maintained above the law of men (Acts 4). The Government is God's servant and this means that it cannot arbitrarily place itself above the rule of law without impinging on the highest authority. If it does so, it becomes the evil-doer (Romans 13), which must be resisted in obedience to God."

And as recently as October 13, 1974, the National Council of the Churches of Christ in the USA adopted a resolution on human rights, the introductory paragraph of which reads as follows:

"Respect for human rights lies at the very heart of our Christian faith. All persons are created in the image of God and are endowed with the freedom to mirror in their relationship to God labour, nature, and society the divine intention for a harmony of love, justice and peace."

2. The second reason I wish to mention is the confusion found within the institutionalized Church to understand the nature of social evil, especially as it expresses itself in forms of violence and of the inability of the Church to draw even upon spiritual and moral resources which it claims to possess in order to counteract such evil by other than violent means.

For centuries the vast majority of clergy and laity in the church thought of violence mainly in terms of physical force or pain. The other many and varied, more subtle and sophisticated, but therefore not less threatening, painful, humiliating, and dehumanizing forms of violence which the human family has devised, sanctioned, and implemented - such as gross political injustice, economic exploitation, psychological terror, or socially destructive systems these have taken many centuries to be designated as forms of violence equally unacceptable, equally and even more destructive than physical violence was usually judged to be.

Today not only the Church as institution but also governments, nations, and human beings in their millions are confronted by the spectre of violence in many of the forms mentioned above. One senses that the wide spectrum of conflict has left many people with a deep sense of confusion, fear and despair, with the most dangerous emotion being that of a deep spiritual inertia which seems to have taken hold of large sections of the human family because the feeling of helplessness in relation to any meaningful resolution of the threat to human rights being found except through other forms of violence. 
This is one of the crucial questions with which the Christian Church and the Christian community throughout the world is faced, together with all the inhabitants of the globe. Deep differences of convictions are being held and expressed on this issue not only within but also outside the organized Church. One is constantly reminded of the fact that long existing situations and systems of oppression and violence called into being struggles where counter-violence was seen to be the inevitable answer to meet and overcome such existing forms of violence, and I do not think that Christ gives us the right to judge or condemn those who, in finding themselves in such situations of tyranny and oppression, have come to the conclusion that, having tried all else, there is no option left to procure liberation but through violence. But I hold the conviction that this is not, cannot be, and will never be the truly satisfying answer which God has made available to his children on earth. I sense - and I admit to my inadequacy or failure in grasping this more clearly - that there is a dimension of divine power and moral force available to us as human beings which we as a Church or as a Christian community have not yet been able to grasp and act upon. In the tradition of such great men as Mahatma Gandhi and Martin Luther King, I implicitly believe that once this divine power of moral force is understood and fully and effectively utilized, it will in turn create a human initiative presently lacking in our society to resolve situations and systems of conflict through other means than those of violence.

One of the essential elements which would be required to operate in order to allow this moral force to display itself is that of voluntary individual or communal suffering on the part of those involved in the struggle for human dignity and human rights. I believe that the Christian community throughout the world needs to reflect much more deeply on the nature of suffering, especially as it has been exemplified through the life and death of Christ, in order to give a more satisfying answer than the Christian community has done up till the present day.

May I now turn for a moment to South Africa, the land of my birth and of my love? For many decades, long before whites spoke out, voices of concern and protest had been raised by black leaders in our country against the oppressive system of apartheid, the most well-known of such voices that of Albert Luthuli, whose consistent pleas for non-violent change, in which he was joined by many others, have been largely ignored by our white community. In 1963 a small body of deeply concerned Christians of all races and denominations in South Africa (called the Christian Institute of Southern Africa) started to join forces with the voices of protest and the pleas for fundamental, peaceful change. During the last eleven years our aims have been ridiculed, our activities have been made suspect, our pleas and warnings have been largely ignored by the majority of the white community of our country. And even when, through fear of being publicly identified with us, a number of whites have privately conceded that the Christian principles regarding human dignity and human rights which we proclaim and try 
to implement cannot be faulted, the customary criticism against us was always one of too great haste. (Significantly, I have not heard of a single black using this argument!)

It would have been much easier for the white members of the Christian Institute to continue to enjoy all the privileges of an unjust society which by its very nature discriminates in favour of whites; it would have so much easier for the black members of the Institute to give up in anger, bitterness, or despair; it would have been possible to retaliate in hatred or even to turn to forms of counter-violence. We did none of these: whatever mistakes we may have made we left nobody, either inside or outside our country, in doubt as to where we stand there. We are committed to the recognition of the dignity and the fundamental rights of every human being, regardless of race, colour, creed or sex; we are committed, in accordance with our understanding of the Christian faith, to do everything in our power to achieve these goals by peaceful means; we are committed to the task of reconciliation based on justice and of Christian liberation through justice without which no lasting reconciliation could be procured. We do not know whether we will succeed - at the present moment it seems more likely that we might fail - but the real and lasting test of success or failure is not always determined by visible signs. Your recognition of our struggle through the honour you have bestowed upon me is in itself a tremendous source of encouragement and hope. But it is also a recognition of the belief which we strongly hold: because this earth is God's earth, such rights must be accorded to all God's children everywhere on this globe.

May I close by quoting part of a soliloquy recently written by John Harriott, a Jesuit priest of Britain, which so meaningfully expresses the hope of the Christian faith which has inspired our efforts in South Africa:

"Let us open the clenched fist and extend the open palm

Let us mourn till others are comforted, weep till others laugh

Let us be sleepless till all can sleep untroubled

Let us be meek till all can stand up in pride

Let us be frugal till all are filled

Let us give till all have received

Let us make no claims till all have had their due

Let us be slaves till all are free

Let us lay down our lives till others have life abundantly." 


\section{DR BEYERS NAUDÉ AND CHURCH UNIFICATION IN THE FAMILY OF DUTCH REFORMED CHURCHES}

Prof. J C Adonis ${ }^{2}$

\section{Introduction}

The topic of church unification within the "family" of Dutch Reformed Churches has long been a matter of much discussion in church circles. This biblical/theological question has, to my mind, coincided with the social-political questions in our country. Within the "family" of Dutch Reformed Churches this question became an important challenge and diligent efforts were made to find a satisfactory answer to it. Over many years Dr Beyers Naudé and the Christian Institute had made a significant contribution in this debate in general, but especially within the DR Churches. In what follows I would like to present and evaluate the contribution that Beyers Naudé has made in this regard.

\section{The background to Beyers Naudé's involvement with church unification}

Early in his ministry Dr Naudé had already established contact with church members and ministers of various churches in our country. Furthermore, his conversations with Dutch Reformed missionaries and ministers who were working with members of the Dutch Reformed Church in Africa (DRCA), the Dutch Reformed Mission Church (DRMC) and the Reformed Church in Africa (RCA) made him aware of the very many different situations in which members of those churches found themselves. He was especially struck by the poor social and economic conditions in which they had to live.

On the occasion of Dr Naudé's seventieth birthday the book entitled "Met de moed der hoop" ("With the courage of hope"), with contributions by 17 authors, was presented to him. This volume presents an excellent overview on the person and work of Beyers Naudé, including the conflicts that he had with his own church and government. After the well-known Cottesloe Consultation he was elected as moderator of his church, the Dutch Reformed Church (DRC) in the former Transvaal. This was after the DRC, under pressure from Dr Verwoerd, had rejected the decisions made at Cottesloe and had broken its ties with the World Council of Churches. During this period Dr Naudé resigned as member of the infamous Broederbond. Shortly after this happened the synod of the DRC in the former Transvaal requested that he resign as editor of Pro Veritate, the journal published

1 Tribute to Beyers Naudé delivered at the celebration of his $89^{\text {th }}$ birthday on 31 May 2004 at the Beyers Naudé Centre for Public Theology at the University of Stellenbosch.

2 Hannes Adonis is professor in Ecclesiology and Church Law at the Faculty of Theology of the University of Stellenbosch. 
by the Christian Institute. Dr Naudé then resigned as moderator of the DR Church in the Transvaal. At the end of this difficult period he also resigned as minister in the DRC and he delivered his farewell sermon on Acts 5:29, "We must obey God rather than men!" ("'n Mens moet eerder aan God gehoorsaam wees as aan mense" $\left.{ }^{\prime \prime}\right)^{3}$

After these traumatic events he joined the staff of the Christian Institute permanently as its director. At the formal opening ceremony of the CI in the Central Methodist Church in Johannesburg (where the well-known Dr J B Webb was the minister) Dr Naudé delivered an inaugural speech about reconciliation. ${ }^{4}$ Later he would mention the persons who meant a lot to him during these trying times: Revs Elias Tema, E E Mahabane, Seth Mokitimi, Dr J B Webb and Joe Wing. Initially he received support from a number of Afrikaners also, but with time this became all the more problematic for them. He discovered here what it means to stand alone before God. It was, however, also during this period that he experienced the meaning of solidarity with another community, especially with the black community.

\section{Beyers Naudés involvement with church unification}

Dr Naudé spoke and wrote on the subject of church unity in the family of Dutch Reformed Churches on various occasions. The mouthpiece of the Christian Institute, Pro Veritate, published numerous of his contributions on this theme over many years.

In one edition in 1985 of the Dutch journal, Rondom het Woord, Dr Naudé wrote on this theme under the heading "Op pad na 'n belydende kerk" ("On the way to a confessing church"). This article was later included in the book Met de moed der hoop (1985), to which I referred earlier. In the above-mentioned article Dr Naudé refers to the situation of the church in Germany during the Nazi period and to the apartheid politics of the South African government. For him the differences and the similarities between the two situations needed to be taken into account. In the emergence of a confessing church, consideration must also be given to the extensive injustice of the policy of apartheid in South Africa.

Regarding the German and South African situations Dr Naudé referred to four similarities between the Nazi regime and the South African apartheid politics: ${ }^{5}$

1. In both situations a policy of apartheid threatened the heart of the gospel. The characteristics of this policy, which both governments shared, were: an

\footnotetext{
See pages 25-29 of this publication - ed.

See pages 139-142 of this publication - ed.

5 "Op weg naar de belijdende kerk." In Met de moed der hoop. Opstellen aangeboden aan Dr C.F. Beyers Naudé. Berkhof, H et al. 1985. Baarn: Ten Have, 167-168.
} 
ideology in which one race was glorified above others and a policy of racial separation adopted in an attempt to maintain peace amongst people.

2. In both countries the "official" churches openly or silently supported the government policy.

3. In both cases the authorities' rules and laws were based on the racial differences of the population. In order to facilitate maintenance of the distinction between race groups, the carrying of identification signs - the Star of David for Jews and the passes for black people - was made compulsory. Separation and control were thus made easier.

4. In both cases the authorities defended and justified their racial policy with the argument that its final goal was the assurance of peace between, and stability and order for, both black and white. In this regard one only needs to be reminded of the millions of black people who had suffered over long periods as a result of the unjust actions of the past. The motivation for these unjust actions has always been that the policies, although it amounts to injustice, it is nevertheless a "minor injustice" compared to the "greater justice" of true peace for both white and black, that it would ensure. In this way, the biblical concept of "liberation" was also unjustly bound to a political policy (apartheid) that in actual fact assured no solution and offered no permanent "liberation" from instability, war and disorder to anyone.

If the situations in Nazi Germany and South Africa were to be objectively compared, the only conclusion could be that there are indeed terrifying similarities between the two.

Dr Naudé then asks whether there really is a need for a confessing church in South Africa. He answers in the affirmative and mentions the following reasons for this: 6

1. The first reason that Naudé, again, gives is that the very heart of the Gospel is severely affected.

"If all the pronouncements by different churches against apartheid since 1948 (the year in which the National Party came to power) were to be examined, many people would be surprised by their number and their sharpness. Yet, not all the churches...could resist this fundamental threat to the Gospel. It was as if for years the power of darkness - dressed as if angels of the light - had blinded millions of Christians. They saw the lie for the truth and the darkness for the light. Only after the World Alliance of Reformed Churches (WARC) declared the theological defence of apartheid a heresy in August 1982 did thousands of Christians realize in their hearts that the ideology of

$6 \quad$ Ibid, 169-177. 
apartheid threatened the church and the Christian faith." [my translation - JCA]

2. Secondly, Naudé cites the unwillingness, inability and resistance of the white Dutch Reformed Church

"It is generally accepted that the DRC helped to build and sustain the policy of apartheid. The close cooperation between the National Party and the DRC was one of the most important reasons why the policy had enjoyed so much support from Afrikaners. During the past 25 years numerous reformed and other churches inside and outside of South Africa had reproached the DRC about its theological backing and justification of the policy of apartheid...Even the theological condemnation by the WARC...could not succeed in convincing the DRC to give up their traditional position on apartheid. On the contrary, the Nederduits Hervormde Kerk (NHK) withdrew its membership to WARC, while the DRC threatened to do the same should WARC decline to withdraw its decisions." [my translation - JCA] This then led Dr Naudé to ask, if these churches acted like this, what hope is there for our country?

3. A third reason for the necessity of the establishment of a confessing church in South Africa was the deep divisions between the three "younger" Dutch Reformed Churches:

1.1 The DR Church in Africa (DRCA):

For Dr Naudé (who was later to become a member and a minister of this church) one of the greatest problems was the complete financial dependence of the DRCA on the DRC. Therefore, this church could hardly take decisions that would be critical towards the DR Church. The DRCA even advised its members against becoming members of the Belydendekring (BK) or in any way supporting them. The BK was an organization of ministers and their spouses of the three black DR Churches. It cooperated closely with the Christian Institute and the South African Council of Churches (SACC). Through its finances the DR Church therefore had a strong hold on the DRCA.

\subsection{The DR Mission Church (DRMC):}

This church responded positively to the decisions of WARC in 1982. Not only did the DRMC support its decisions and condemnation of apartheid, but also went further to draft and adopt the Confession of Belhar. This confession served as basis for discussions with other DR Churches in the family. The Belhar Confession once again demonstrated the DRMC's rejection of apartheid.

\subsection{The Reformed Church in Africa (RCA):}

This church was also financially very dependent on the DRC. Naude then refers to the example of some ministers in this church who, to counter this state of financial dependency, decided to become tentmakers (ministers who sought 
part-time employment in the secular sphere) to alleviate the financial burden of their ministry on their congregations. Three DRC ministers working in the RCA, namely Klippies Kritzinger, Charl le Roux and Gerrie Lubbe, decided on occasion to become members of the RCA, thus ending their membership of the DRC. This led to all three of them being deprived of their status as ministers of the DRC. However, the respective church councils and congregations where they worked refused to act against these ministers. The final outcome was that the synod of the RCA could not meet to take any action against the ministers.

In his article in Met de moed der hoop Dr Naudé further declares that apartheid is a deadly poison that streamed into the veins of the church of Christ in South Africa and that has poisoned every part of the body of the church. Furthermore, he maintains, that a confessing church is born where Christians in obedience to Christ endure oppression, persecution, mockery and suffering, and in their desperation and suffering turn to God in prayer, in faith and in hope so as to remain standing.

Subsequently Dr Naudé mentions a number of features of a confessing church in South Africa:

"1. It is a church that categorically rejects the theological justification of apartheid and that challenges it in its confession, ministry, catechesis, training of ministers, diaconate, ecumenical relations, evangelisation, etc. Even the faintest traces of racism, apartheid and racial prejudice must be eliminated from its midst.

2. It must be a church that strives tirelessly for church unity between churches of the same confession, but also with churches of different confessions...The yearning for unity ought to be spontaneous and must not be enforced... This tree can only bear fruit when new life grows upon a basis of neighbourly love, truth and justice.

3. It must be a church that strives for political justice for all inhabitants of the country... The church will have to actively fight against all laws and regulations of the government that stands in conflict to the Gospel...

4. It must be a church that strives for economic justice...

5. It will be a church where mutual love and community will be encouraged and strengthened through worship and service. Where faith, joy and hope must characterize its worship, witness and service...

6. It will be a church where small groups of Christians will meet across the boundaries of existing denominations, culture, race, 
class and gender to confess their faith together..."7 [my translation $-\mathrm{JCA}]$

According to Naudé, a confessing church is the church of Christ that wants to live and witness in obedience to His Word. Finally, he also realizes that the establishment of such a church is not a simple or easy matter, but he emphatically expresses the expectation of and the hope for a visible community of Christ, the reign of His Name in every terrain of life.

\section{Dr Naudé and the unification of the DRCA and DRMC (1986-1990)}

Within the family of D R Churches many discussions were held over a long period of time about church unity. Because of differences within the family no definite decisions could be made to unite with one another. However, the DRCA and the DRMC decided in 1986 to enter into discussions with the purpose of church unification in 1990. The two discussion groups of these churches started the process in all earnest. The representatives were as follows: ${ }^{8}$

Members of the DRCA: Members on the DRMC:

SP Buti

LKC Mabusela

MM Maphoto

LW Mazamisa

TA Mofokeng

CFB Naudé

MS Pitikoe

SO Skeen

NJ Smith

EM Tema
JC Adonis

NA Apollis

AA Boesak

AJ Botha

JJF Durand

IJ Mentor

JJF Mettler

PJ Robinson

DJ Smit

The unification discussions between the two churches took place alternately in Belhar and Johannesburg. The first meeting was held in Johannesburg on 9 September 1987. The aim was to unite in 1990, but because of a legal difficulty the new church could only be founded on 14 April 1994. From the inception of these discussions the DRC and the RCA were always invited to take part. A copy of the draft church order was also sent to them.

\footnotetext{
$7 \quad$ Ibid, 175-177.

8 Skema van werksaamhede, 25ste Vergadering van die Sinode NGSK 20 Sept. 1990, N G Sendingkerk Sentrum, Belhar, p. 50.
} 
Declaration of principles of the DRCA and DRMC:

\section{"1. Church unification}

The delegates of the two churches bore communal witness to the Biblical teaching that the unity of the church must be made visible in one, single Dutch Reformed church. This means that the existing institutes will have to unite in a single institute organised according to the reformed church law and denominational context. Race considerations will play no role in the organisational arrangement of this church. Language and cultural differences may not adversely affect this unity of the church, as is the case with any other ministry needs. Such differences will be managed in accordance with normal procedures and will serve the purpose of mutual enrichment within the one, single, visible church.

The two churches consequently commit themselves to initiating this process of unification and encourage all efforts within the churches of the DRC family that may put in place and serve the purpose of eventual unity.

The two Reformed Churches (DRCA and DRMC) together confess their remorse about the way in which they had prohibited the growth of visible unity within the DRC family over the years.

\section{Reconciliation}

The two churches declare as their heartfelt conviction that the style of the church's functioning ought to remain one of reconciliation, peace and love. The church is the unique new creation of God - people who are reconciled to one another through the blood of Christ and who now live in peace.

The two churches are furthermore firmly convinced that true and lived reconciliation between Christians in our country will bring about new living possibilities in our polarised society. People who are estranged from one another and who distrust, fear and even hate one another may now learn to trust, love and serve one another.

The two churches confess that God's Word and Spirit are able to reconcile people with each other despite all natural differences between them. We mourn the fact that for years in our country this reconciliation has been made difficult and even impossible through the enforced separations of apartheid and separate development.

The two churches are under the deep conviction that reconciliation does not mean covering up disputes and glossing over the wrongs. We therefore declare that a cheap reconciliation in our country - in other words merely favourable dispositions and one-sided, patient 
endurance of injustice without dismantling that injustice - is not the way towards Christian reconciliation.

The two churches are deeply aware of the pain that a process of true reconciliation will bring to all of us. It will include, amongst other things, the dismantling of ideas and of ecclesial and societal structures that have grown over many years. Yet we remain convinced that the Gospel demands this from us all and therefore we declare our willingness to venture this road with each other.

\section{Justice}

The two churches confess their conviction that God revealed Himself as the One who wants to bring justice and true peace amongst the people; that $\mathrm{He}$, in a world full of injustice and enmity, is in a special way the God of the suffering, the poor and the wronged, and that $\mathrm{He}$ calls his church to follow Him in this.

The two churches confirm their stated convictions that the political and social policy of apartheid (or whatever other name this was given over the course of time: separate development, own affairs, etc.) and the dispensation brought about by this in our country is a sin that did injustice to people and encroached their human dignity; that it therefore encroached the principle of justice and neighbourly love; that it therefore violates the principle of justice and neighbourly love; and that all attempts to openly or silently justify any such a sociopolitical policy on Biblical grounds is a heresy that jeopardises the credibility of the Christian religion.

The two churches declare as their mutual conviction that the Godgiven dignity of every person must be respected; that in the name of justice, human rights must be urgently striven for in our country, preferably in the form of an enforceable legal code that will also protect the rights of the vulnerable.

The two churches express their deep concern about the present spiral of violence in our country; about the structural injustice and violence that for many years has had a serious effect on human dignity; about the fact that by far the majority of the citizens of the country are excluded from normal, orderly political participation, with the result that many have come to feel that non-violent resistance against injustice has been repeatedly applied and repeatedly shown to be in vain; about the large number of political detentions without trial, including the detention of children; about the fact that the majority of the population in our country cannot take part in the political debate; about the countless instances and reports of instances of both revolutionary and oppressive violence in our country; about the way in which the lie is proclaimed and the truth is suppressed through 
media censorship, withholding information, propaganda and subtle ideological indoctrination of the population.

The two churches together pray for a speedy, true peace built on justice and call on all members to likewise pray and work for this."

\section{A Draft Church Order}

A church order is an essential instrument for the governing of the church. In Proverbs 21:15 we read "When justice is done, it brings joy to the righteous..." For the new church order in the new church the following principles were established:

1.1 The reign of Christ in the church;

1.2 The central importance of the Word;

1.3 The equality of the offices of the church;

1.4 The unity of the church;

1.5 The church as instrument for reconciliation;

1.6 The church as instrument for justice;

1.7 The church as serviceable to the poor and people in need of its full meaning;

1.8 The active participation of members by placing the office of the believer at the centre;

1.9 The freedom of the church, which means that the church must be less legalistic, rigoristic and managed top-down; it must be more flexible and spontaneous.

\section{Conclusion}

As a member of the discussion committee on church unification between the DRCA and the DRMC, Dr Naudé, together with the other members, played an extremely important role. As mentioned above, the duration of this process extended from 1986 to 1990. His years of experience, commitment and wisdom on ecclesial and other related matters placed him in a position to make a constructive contribution to the process. The two sermons, "Christus bo alles en almal" ("Christ above everything and everyone") (1 Cor. 2:2) and "Ons moet aan God meer gehoorsaam wees as aan mense" ("We must obey God rather than men!") (Acts 5:29) that he delivered at the Aasvoëlkop DRC congregation on 27 May 1962 and 22 September 1963 respectively, are for me a telling reflection of his life. It is then not

9 English translation of the Skema van werksaamhede, 25ste Vergadering van die Sinode NGSK 20 Sept. 1990, N G Sendingkerk Sentrum, Belhar, p 36-38. 
surprising that he clashed with the political and ecclesial authorities of his time on matters such as justice, reconciliation and unity. Dr Naudé practised what he believed and confessed it in his service as minister, as director of the Christian Institute and as secretary of the SACC.

There was great joy and gratitude to God for the founding of the Uniting Reformed Church of Southern Africa on 14 April 1994 at the Belhar synodal centre. The delegates at the inaugural synod embraced each other for minutes and praised God. Dr Naudé was present also and deeply thankful to experience such a moment. Finally, one also gets a glimpse of the high regard in which this man was held in the new URCSA when, in Bloemfontein in 1997, he was invited to address the assembly of its second general synod, even though he was not a delegate to that synod, as a mark of the recognition of his role in the founding of the URCSA.

I thank you. 
Which South Africa are we talking about? This is the question which we have to ask and answer before we enter into a discussion on the meaning of confessing the faith. Are we talking about the South Africa of Sun City, of Sol Kerzner, of the Gerrie Coetzee title fights or of the glamorous beauties invited from all parts of the world to this international playground - or are we talking of the unknown millions who are desperately struggling to find a platform for their call to justice being heard? Are we talking about the South Africa of the overcrowded match-box homes, empty schools, protesting students, teargas and bullets, injury and death? Are we talking about families planning their Christmas parties and gifts at a holiday resort or overseas - or are we talking about families in poverty, hunger and want, barely being able to prepare a full meal for Christmas day? Which South Africa are we talking about?

Why do I ask this question? Simply because we do not have one South Africa in which all of us live - we have at least two deeply divided communities each living in their own ghetto, each largely isolated from the other - strangers to one another in this one geographical area called South Africa! Whoever does not recognize this tragic fact, this bitter reality, does not recognize the deep divide which evokes the question: Which faith are we talking about?

People would respond by saying: "But surely we are talking about the Christian faith?" Yes - but which face of the faith are we looking at? Is it the face of the pietistic evangelical approach of individual salvation, is it the face of the charismatic groups, is it the face of the fearful seeking refuge in churches and worship gatherings like those of the Rhema Bible Church - or is it the face of those who believe God is God of justice and peace, a God who is on the side of the oppressed, a God who seeks liberation of all who are in bondage? Authentic confession of the faith, I believe, can never be made in a political, social or economic vacuum, in a situation unrelated to the life and struggle in which Christians find themselves from day to day. In order to make the confession of one's faith meaningful it has to be done in the context of a specific situation with a clear understanding of how one sees and interprets the community to whom the faith has to be proclaimed. And if you were to ask me what the main characteristics are of the situation in our country today, I would wish to describe it with this

1 Excerpts from address delivered on the occasion of the $10^{\text {th }}$ Anniversary of the Belydendekring in Mayfair, Johannesburg, 8 December 1984. (Originally published in Belydendekring Bulletin, 15 December 1984, Vol. 2 No. 12, p. 1-5.) 
phrase: a situation of crisis. And the awareness and almost daily experience of that crisis is recognized or felt much more deeply in the South Africa where the majority of the people live and struggle, that the South Africa of the white minority living in splendid isolation and to a large degree unaware of what is actually happening in the country as a whole or, if partially aware, to a remarkable degree unconcerned about what these events imply...

Ten years ago a small number of ministers of the three younger members of the NG family came together realising the increasingly evil effects which the whole apartheid policy was having on the life of the church and of the community. The outcome of their concern was the establishment of a small, insignificant organisation called the Broederkring, brought into being with two main goals: to seek the organizational unification of the family of four NG Churches in South Africa and to express its total rejection of the policy of apartheid as unchristian, immoral and dehumanising. The basis on which this organisation was founded should be seen as a form of confessing the faith to themselves and to all those who were interested in joining the Broederkring. That did not imply that the members of the Broederkring wanted to limit the confession of their faith only to these two issues and areas of life, but for them it was a moment of realization that unless and until more serious and concentrated attention was given to these two spheres of life in the Christian community of South Africa, no Christian witness in any other sphere would have the necessary relevance and possible significance for the future. There were reasonable hopes at that point in time that some of these aims would be realised in the foreseeable future. After ten years of existence we have to admit that to a large degree neither of these two major goals has been realised. The entrenched power of the whole apartheid system has been so strong and so well supported by all those who benefit from the system, both inside and outside the country, that it could still take us decades before this goal will be realised. It is important to look at the situation in each one of the churches that form part of the NG family namely the White NGK, the NGSK, the NGKA and the RCA, to establish where we stand today. As far as the White NGK is concerned, there has been no indication of any change in a policy or outlook, despite many claims which have been made by the leadership of the NGK. We are deluding ourselves if we believe that any meaningful change could come from within the NGK, at least as long as the present official leadership remains in power. And, even if a new membership has been so successfully introduced with the concept of apartheid, it would take many years before the NGK could make any real contribution to the process of change in our country.

The Belydendekring soon discovered in its attempt to realise the goal of Christian unity and of social justice that this would be impossible to achieve without taking a clear stand on the issues of political justice and human rights. Throughout the long years of apartheid rule the government has entrenched itself so deeply in order to maintain its stranglehold of power on society that there is not a single sphere of 
human life in South Africa which is not in some measure controlled, directed or affected by government rules and regulations. In no sphere of life is the violation of the basic concepts of political justice so seriously violated as in the area of the political rights of the black community. A situation has developed where the almost total political rightlessness of the black community in excluding it form the future of South Africa, has created one crisis after the other. To this crisis of injustice the Belydendekring will have to address itself if it wishes to remain true to its basic goals and aims. This is the tragedy of the Christian faith in South Africa that so many denominations, including so many Christians, do not see a direct link between their Christian faith and the need for fighting for the political rights of others. If there is one major area of concern where the Belydendekring will have to take a stand and, if possible, to give direction, it is in the sphere of the political future of the Black community of our country. Any refusal to face up to this challenge will increasingly make the Belydendekring an irrelevant organization, claiming to be Christian, but failing in one of its basic Christian obligations.

But increasingly the Belydendekring has discovered that the whole issue of riches and poverty, of wages and employment, of the relationship between management and labourer, of worker rights and responsibilities are all part of the Christian witness which we need to understand and to address. South Africa finds itself in the unique position of being, on the one hand, a clear representative of the First World (economically privileged, highly industrialised, technologically far advanced, white minority dominated) and, on the other hand, being at the same time part of the Third World (underdeveloped, impoverished, exploited and oppressed in many respects). We are fully aware of the fact that the present capitalist system is rejected by the majority of the people of this country as a system which is basically exploitative, unjust and discriminatory. We are also aware of the fact that increasingly the young generation of our country is seeking to find or to create an economic system and structure which is more in accordance with their concept and understanding of justice and equality. To a large degree the church in South Africa has not even begun to express itself to this increasing awareness and demand on the part of the youth of South Africa. If the Belydendekring wishes to give concrete expression to its understanding of justice in the biblical sense of the word, it is imperative that we take more seriously the need to prepare ourselves through study, debate and discussion and action to discover and present an economic system which is more in accordance with the biblical criteria of justice, freedom and human dignity than the present capitalist system of free enterprise which is operating in South Africa today. This will require a critical self-appraisal of our personal lifestyle, of our lack of involvement up till now as Christians and as churches in the struggle of the trade union movement for basic rights for its members. It will require a confession of the Church's lack of interest and involvement in the struggle of millions of people for basic rights, income, conditions of employment and expressions of the dignity of human labour. Our 
confession should include an admission of the church's traditional attitude to the whole labour and trade union movement of being largely uninterested and uninvolved. This raises the serious question about the understanding of our theology, about the contents of theological training of ministers in our theological schools and faculties. To all these issues the Belydendekring will have to address itself if it wishes to be obedient, even to some degree, to the biblical understanding to justice with regards to the provision of the daily bread to each member of our society. Have we ever begun to ask ourselves what the full implications are of the prayer which we so constantly participate in: Give us this day our daily bread?

If the Belydendekring wishes to give expression to its confessing the faith in South Africa, it cannot ignore or bypass the cry for educational justice which is coming from the heart of millions of young people of our land. If in any way we are seen to be uninterested or uninvolved through fear or whatever other reasons, we cannot blame the youth of our county if in exasperation they turn away from the Christian church, the Christian faith, and the Christian people. I pray that this will never occur, but I fear that to a certain degree this process has already started and is under way. If the Belydendekring wishes to make a meaningful confession of its faith in South Africa today, part of that confession will inevitably imply our becoming more deeply involved in the struggle of millions of young people to achieve some form of justice for their educational needs and problems. It will require that the Belydendekring should address itself more seriously to the contents of the Educational Charter, to the needs of the students, and to the challenge being presented to us in some way which is acceptable to the student community. We should give them the necessary moral and concrete support. 
Thank you so much for this opportunity. We have been listening with rapt attention all morning to the experiences of others with Bey Naudé and the impact of his contributions to the work and life of this country and the church. This has really taken me back to some of the most important moments of my own life.

\section{The crossing of my path with that of Beyers Naudé}

I met Oom Bey in 1963. I was then a very young 17-year-old student at the University of the Western Cape. It was the decade that the Group Areas Act had begun to have its impact on the places where we lived and grew up. It was three years after Sharpeville, which, for the young people of my generation, had been the wake-up call to the reality of the political situation in this country. By then generations of black people had already committed themselves to put their lives on the line for the struggle and for the ideals that we, members of my own generation, had only just began to understand in those days. I was not totally politically ignorant though. At high school I had teachers who were part of organizations such as the Teacher's League of South Africa that had to work mostly underground. We read pamphlets called The Torch - I don't know whether any of you have ever seen it or remember it - and had after-class discussions about the real history of South Africa. I was just becoming more acutely aware of our own circumstances at home. I realized how my mother had to work under humiliating circumstances for a mere pittance, and what it had cost her to give her children the bare necessities of life. It was a time where I had begun to understand in my own life what the system called apartheid meant.

I was very angry. I did not yet know how to deal with my anger, but I knew that something had to be done with it. This was the year in which the Christian Institute was formed, and in which Beyers Naudé came to Somerset West to speak at St Saviour's Anglican Church. I was there and I listened, and firstly, I was quite wary because I could not think that a white person could say these things and be serious about them. Secondly, I could not begin to understand what that would mean for me, what benefit I would derive from all of this. It took me two years to think about that. In the meantime I went to Wellington to begin my proper training as a minister in the Dutch Reformed Mission Church.

1 Tribute to Beyers Naudé delivered at the celebration of his $89^{\text {th }}$ birthday on 31 May 2004 at the Beyers Naudé Centre for Public Theology at the University of Stellenbosch.

2 Allan Boesak is minister of the Uniting Reformed Church, Piketberg. 
In 1965, when the Theological Seminary of the DRMC was established on the campus of the Western Cape, I was a part of a student group who decided to invite Bey Naudé to come and speak at the Seminary. We had this gathering once a week on a Thursday, the very last period of the day during which we could invite a speaker, have a debate or a discussion. We decided that Oom Bey should be a speaker at one of these occasions. Of course it raised immediate difficulties with the Board of Professors and we were told that we would not be allowed to arrange such a meeting. We wanted to know why our request was denied, but they could not give us a proper response. We then decided to comply, by simply moving the time of the meeting to that same afternoon. We were then told directly that should we invite this man to the campus, steps will be taken against us. I was then 19 and had already realized, and decided, that I would have to fight these people, because I wanted so much to have Beyers Naudé speak to the students at the University of the Western Cape, at the Seminary of the Sendingkerk. If what he had told me two years before, which had had time to grow inside of me, could have such an impact on me, I thought it would have the same impact on my fellow students. The Seminary authorities then decided, after banning Oom Bey from speaking to us, to invite Oom Koot Vorster to come as speaker instead. Students who were not present, we were given to understand, would somehow feel the dire consequences of their absence in the future. So Oom Koot Vorster came and he spoke to us on the subject "Wat is 'n liberalis?" (What is a liberalist?). Apparently it was something he did often in those days.

\section{The way of Beyers Naudé: Confrontation}

I have mentioned all this because my first meeting with Beyers Naudé meant for me an understanding that along this road he was following and advocating, and on which I was prepared to follow him, there would be clashes with the authorities of my church and my seminary. These clashes became an almost daily part of my life in the years that followed. But then also there were a number of other ministers from the Mission Church - not many, two that I can think of - who at that stage had already had contact with Beyers Naudé. I'm thinking of Rev. John Plaatjies, who, because of his own commitment to justice and because he spoke the language of the Christian Institute in the Dutch Reformed Mission Church, had to leave the country. The government forced him out and my church in its official capacity, by way of its authorities, its moderamen, did not move a finger to help or support him. I am also thinking of Rev. Izak Theron, who became so disillusioned with the Sendingkerk that he felt he had to leave the church, forming his own little congregation in Paarl. I also remember when I became a minister in my first congregation in Paarl, one of the first clashes that we had in that Presbytery was because of Sakkie Theron and his open and public support of the Christian Institute, and my subsequent support of him. 
Beyers Naudé, because of what he stood for, because of what he said, because of what he was not afraid to say, because of the example that he felt he had to set, caused conflict. And you had to make up your mind whether in the course of your life you would enter that conflict and remain within it. Can you live with the conflict that this man brought with his testimony in your life? I was lucky, I suppose, in many ways, that he came into my life when I was still young. It is then that you have enough fight in you to say that it is fine, I will accept it. Of course, none of us knew where this would lead. Nobody had an idea where it would ultimately end up. Nobody really understood where they were going to go. You knew you had to follow that road, but you had no idea where you would end up. Beyers Naudé did not, nor did I or many of the others who decided to follow this path.

The conflict Beyers Naudé brought into our lives was because of his conviction that what was happening in our country and in the church, specifically the Dutch Reformed Churches, was so fundamentally wrong. And there was no way, if you shared that conviction, if you wanted to stand side by side with this very remarkable human being, in which you could avoid confrontation with those who decided that they would continue to defend the status quo. This was not a confrontation for the sake of confrontation - this I also learnt from Oom Beyers Naudé. It was a confrontation for the sake of the truth. He was not fighting with people because he enjoyed it so much. As a matter of fact, we often talked about the incredible pain that it caused Oom Bey to fight the Dutch Reformed Church. Because it was his own church, and in a sense, even though he later became a member of the Dutch Reformed Church in Africa, he remained in his heart a white Dutch Reformed Church minister. I'm not saying the latter in a derogatory fashion. What I mean is that he could never, ever, see himself as completely cut off from the church in which his ministry began in the first place. Thus, the pain that he lived with was a pain that was unavoidable. It was not that he loved to tell his former fellow church members how wrong they were. He loved Jesus more, though; and he had to speak the truth. That is what I learnt from him, the way to go, and also, how difficult it is to make people understand that "I'm not fighting you because I like fighting you". Your own people hate you when you stand up and say they are wrong, when you want them to understand when you say: "I'm fighting you because I want you to understand the truth which you, somehow, seem to have let go of. In a way this diminishes you, it diminishes your calling, it diminishes me together with you." Oom Bey experienced that. I don't know how many people understood that as he went on from place to place, speaking to them, appealing to them. And, of course, Dr Anthonissen is correct when he says that even after Oom Bey had left Aasvoëlkop, many, many years after, people were still saying they 
could not understand why he left. ${ }^{3}$ And they never would understand the pain that it had caused him to leave. He, however, had no choice.

So, Beyers Naudé brought confrontation and Beyers Naudé confronted you with choices. I do not know whether there is any person who, in having had the privilege of meeting this man, talking with him, who did not find that all of a sudden they were confronted with choices that they would rather not have wanted to make. It would have been much easier to go on with one's life without having had that talk, without having had that meeting, without having had a glimpse of what had driven this man. But once you have met him, and once you did open your mind and your heart to him and to what he said to you as you spoke with him, you found that you had to make some serious choices about yourself, about your ministry, your way of understanding others and about the issues of justice and peace. You had to make choices about apartheid, the church and about the world in which we live, and ultimately, about the Gospel. That was, at least, my experience. And those were the choices that would haunt you until the issues that you knew confronted you were resolved. This I learnt from him as well.

\section{The way of Beyers Naudé: Reconciliation}

It was only in 1981 that I wrote something called Black and Reformed - burden or challenge? That, however, was something that had been burning in me since 1963, of course. Oom Bey was Reformed and I was Reformed. He was white Dutch Reformed and I was Sendingkerk. But then what? I mean, here we come from totally different worlds and here we are in a situation where we were thrown together by God, to do things together for a cause greater than ourselves. And even in those days the question haunted me: how could you say that you are a Christian in this country, when apartheid was designed by Christians? Even closer to home: how could you say that you are Reformed, and how could you be proud of that heritage, when it is the white Reformed Church, in all three of its forms and shapes, that caused this policy to be devised and implemented, and which called it Christian, biblical, and found all those sophisticated theological arguments to justify it? How could you be Reformed, how do I defend myself when I meet other people and we talk about the impact of the Gospel on your life, and you talk about the Bible, or you talk about your tradition?

The full implications of all of this I learnt in the Netherlands. Oom Bey was a theologian but not that deep thinking a theologian. But that's fine. He told me: fundamentally, these are the basic truths on which you have to stand that what you see around you. What they teach you in that Theological Seminary down in Bellville, what they make you read, what they make you believe, is not important.

3 See C A Anthonissen: Beyers Naudé's Relevance for the DRC Today. (See pages 143-150 of this publication - ed.). 
Don't - ever - believe it, and don't be ashamed of what the Reformed tradition really is. Roelf Meyer was the one in the Christian Institute who gave content to that in writings afterwards in publications such as Poverty in abundance or abundance in poverty, published by the CI in 1973.

Oom Bey was very clear about apartheid theology, and we don't have to say too much about that. But he was also very clear about the social, political and economic responsibility of the church. This was yet another thing I learnt from him. But there was also something else I learnt from him to which I referred earlier. I told you that when I met Beyers Naudé I was a very angry young man. I really had very little time for white people. I was angry also because I could not go anywhere without bumping into them. I was becoming a minister of my church, and here I had all these old, white Dutch Reformed Church professors teaching me things, so that I thought: this is not right! I knew it was not right. And yet you had to write your exams, and if you want to pass, you had to write the things they wanted to hear.

Oom Bey was the first person from the white community with whom I had any intimate kind of contact that made me question my own anger and my own mistrust. He was the first person who made me ask the question: if you can accept him, how can you continue to simply judge people because of the colour of their skin, the other people who are classified white in this country? If he has been able to change, how can you close off the same possibility for others who look like him? If he can convince you of his own humanity and his own truthfulness, how can you preclude others from doing the same? I will forever be grateful for that experience. And those of you who have read things that I have written ever since that time would know that I have said this openly over and over again, because I think that was such an important moment in my life. When you can come to the point where in the midst of South Africa's racial tensions you are able to judge people, not on the basis of the colour of their skin, but on the content and the character of their commitment to the issues of justice, then you have made almost indescribable strides.

I did not understand, even then, in 1963, what impact this realization would have on my life. I realized it later though, when I became an adherent of the Black Consciousness philosophy and learnt how important it was for me to accept my own blackness and my dignity as a black person, before I could accept the challenge and correctness of non-racialism as we moved toward the establishment, philosophy and work of the United Democratic Front.

The debates raged on about the question of whether white people would be allowed to participate with us in the United Democratic Front. These were fundamentally serious debates in those days, debates on identity and personhood; about black dignity and the true basis of human equality, about ownership of the struggle, the past and the future of our country. These were also debates on 
whether you could believe white people when they said they supported the struggle. There were fears that if you allowed them to join the struggle, they would dilute it with their white classism, with their position of privilege, their own views on life and with their white, liberal political thinking. These were the issues that caused a number of people to turn their backs on the UDF and go their own way. These philosophical decisions had to be taken. I was fortunate enough to have been able to talk to a person whom I knew and with whom I had experienced something fundamentally important: if this man could be the way he is, and do the things he does, how can we judge others? How can we exclude them? How can we say: "There is no room for them?"

I think, more than Oom Bey ever knew or understood, that that is what he had loosened up in me and what others could discover in him which helped us through those debates. By the time we launched the UDF and I had to make the foundational address of that organization, the theme of reconciliation and the theme of white people and black people working together for the sake of justice in our country was already accepted. Oom Bey helped us to understand what the politicians came to understand only in the 1990s, when they began to talk about reconciliation. It did not fall out of thin air, it was not "discovered" with the coming of Madiba Magic. It was something that was implanted in us, even in those very, very difficult days. The people who helped us grapple with, understand and take this through to its logical conclusion were people like Oom Beyers Naudé, his life, his witness and his convictions.

\section{The way of Beyers Naudé for the future:}

What, with an eye on the future, can we learn from this man, apart from what we, who have known him for so long, know?

I think the first thing that we have to learn and which is crucial today, is the fundamental truth that when God calls, you have to say "yes". It's not going to be easy. It is going to bring you to places where you might not ever have wanted to be, and when you get there, you might wish that you were not there. Your answer might cause misunderstandings and confrontation, might make you have to cut your ties with people you love most, make you feel as if you're betraying others, while in reality it is they who are betraying you. When, however, God calls you, you have to say "yes". If we do not understand that now, then this whole exercise this morning would be in vain.

The second thing is this: you should not be afraid to be ahead of your time. My friend Okke Jager, who died far too early and who was one of the most brilliant theological minds in Holland, once said that one of the greatest sins in the church is to be ahead of your time. The Church does not forgive this easily, because when you are ahead of your time, you tell the church to be in places where it is not ready to go, and it might hate you for that. You call the church to do things it is not even 
thinking of doing right now, and it does not like that. You put the demands to the church when it is still in the place where it wants to hide from all responsibility. Oom Bey had struggled with this and by the time he made the decision to leave Aasvoëlkop and go to the Christian Institute, he had discovered: "I have to be in this place." He was ahead of his time. And the greatest reproach that I have heard from white Dutch Reformed people in my company about Beyers Naudé was that he moved too fast for his own people, that it was too soon for the decisions he took, that he embarked upon a way his people could not understand or follow. He was simply too much ahead of his time.

If Beyers Naudé had, however, decided to wait for the majority in the white Dutch Reformed Church to come to the place where he was at in 1963, then he would have been there today still. The fact that he moved on ahead of them, that he got there on his own, showed that even though they did not find the courage to move along with him, it was in fact possible to get there. But what happens to you on the way to where you have to go? That is another question. But you can go there. And if Beyers Naudé had not gone there, there would not be people in the Dutch Reformed Church who had seen, and see today what God saw and what Beyers Naudé saw. There would not have been those who have realized that there was a different way to go, a different place where they had to be. Where we are now might be comfortable, but it is not right.

The other day, here in Stellenbosch, the VGK - the Uniting Reformed Church celebrated its $10^{\text {th }}$ year of "togetherness", as they called it. I listened to the speeches that were made by the moderators of the family of Dutch Reformed Churches. I listened to a speech that, coming from the white side, really surprised me and encouraged me, because I thought: finally, now we're going to do something! And then there was another speech that I listened to from the white church side that made me terribly depressed. It was raising the same issues I used to discuss with my old friend, who is no longer with us, Professor Johan Heyns. Johan Heyns at one time said to me: "The problem is, I cannot as a leader, afford to be too far ahead of my church." That was 20 years ago. Now, ten years into the new democracy, it seems the leaders of the white Dutch Reformed Church are still saying the same thing. What I am saying is that, if we do not learn from Beyers Naudé to take the risk with God, to be ahead of our time and ahead of the comfortable place where many in our churches want us to be and remain, we will never be truthful witnesses to the Gospel. We will get stuck where we are, because there are too many excuses not to do anything.

The third thing is that the integrity of Christian witness lies in the choices that we make, not in our words. It does not lie in the sermons, not even in the synodal commissions that come together now and then. It does not lie in the fact that Stellenbosch now has a multi-coloured faculty. It lies in the choices that we make. I 
discovered a long time ago: we are the chosen people of God, but the chosen shall be known by their choices.

Finally, it is a very dangerous thing to take someone's name and link it to your institution - to your school, your church, club or whatever. Madiba carries a heavy load in South Africa, and one of the reasons why his load is so heavy is that there are so many institutions named after him that have no clue of what he stands for. But they get his name because he's kind and he's loving, and they think they can get lots of money by linking themselves to his name - and they do. Now the question remains: what do we do with this legacy, this name, to which we have linked this institution, the Beyers Naudé Centre for Public Theology? How do we honour this name, how are we honest with regard to it? It should not simply be a name that raises money. What must concern us is that the name challenges us, in terms of our own integrity, to be truthful to what the bearer of that name stood for, fought for and was prepared to die for.

So now you have this thing you call the Beyers Naudé Centre, and it is a wonderful name. This institution must ask itself: how do we, in terms of all the things that we have discovered, or rediscovered about this man once again today, honour this name, and how do we keep our integrity? That is your challenge. As I move from this rostrum and as you move forward as an institution, I pray that God will give you the strength, once you are able to bring to life the spirit of Beyers Naudé in this institute, to do what God has called us to do. Then you will do what is right - by him after whom the Institute was named and before the God who had given him to us for such a long time.

Thank you. 
I am greatly indebted to the Executive Committee of the Board of Management for their decision to hold this ceremony and for the opportunity thus created to give this short address as newly appointed Director of the Christian Institute.

I have chosen as theme the concept of reconciliation as elucidated in 2 Cor. 5:14-21 because of reasons which may be obvious to some of you but which, I hope, will become quite clear to all of you as we proceed. Let us, for a moment, give our attention to the term; not only is RECONCILIATION a Biblical term, but it is quite clearly a Biblical truth - a New Testament concept which we should grasp and apply in honesty and humility if we want to call ourselves Christians. This is wholly a Christian concept, because the world knows and understands nothing about reconciliation. The world knows about compromise and concessions, yes, and appeasement and adaptation, but reconciliation is a totally new concept, which only the New Testament has proclaimed because it means in essence the supreme act of sacrificial love of God to restore the true relation between God and man and between man and man.

This reconciliation could only be realised through a supreme act of sacrifice such as became reality when the Son of God became man in the fullness of time. This was the true meaning of the Incarnation - to demonstrate to the whole world through all ages that in Christ Jesus God had become the great Reconciler.

\section{What does this imply?}

1. It clearly implies that a totally new relation between God and man has been created in which man discovers, to his ever-increasing amazement, a new attitude and a new acceptance on the basis of his forgiveness that God bestowed which Christ not only preached but also practised. Therefore: forgiveness is an absolutely essential element in the whole concept of reconciliation; without willingness to forgive all truly and fully, no reconciliation is possible. And the life of Christ is the perfect proof of that. Do we realize the challenge this holds for us as Christians: that as long as we harbour a spirit of unforgiveness in our hearts, any reconciliation is made impossible? That we are, in fact, thwarting the purpose and will of God?

1 Excerpts from Beyers Naudé's inaugural address as director of the CISA, on Sunday, 15 December 1963, in the Methodist Central Hall, Johannesburg. (Originally published in a collection of sermons of Beyers Naudé, My Decision, by the CISA n.d.: 2-27.) 
2. We must also realize that this offer of God was made not to his Church, not to Christians as a separate group, but it was made to the world - this world of ours, of people and nations gone astray, lost in their hatreds and strifes, their fears and prejudices, their selfishness and waywardness, their disunity and bitterness. It is this world - a world in which all peoples of all races and cultures and social standings are included - that God has reconciled unto himself. Do we realize the direct challenge this one word: WORLD in 2 Cor. 5:19 brings to us? How far does our world go? Do we include - and exclude - in our love and fellowship those whom God includes and excludes? Or do we build up our own walls and barriers contrary to God's command?

3. This concept of reconciliation also implies very clearly that to God this was meant not only as a verbal message to man, but that it had to become incarnate; an audible word had to become a visible deed in the flesh before reconciliation could become effective. This was the price God was willing to pay - the Incarnation of Christ the Reconciliation of God with man. Do we realize what this implies: that all talk of reconciliation remains meaningless and even becomes dangerous if words are not transformed into deeds? Do we realize that our confession of faith becomes nothing but cheap talk, yes, becomes an act of hypocrisy if we do not fully accept and enact the reconciliation of God in our lives?

4. If once the New Testament concept of reconciliation is properly understood in its meaning of God's relation to man, then we begin to understand what this implies in our relation of man to man. If God in Christ has enacted the great Reconciliation between Him and us then we begin to realize that all human relations are thereby affected and transformed. A new quality and content, a new spirit and approach thus become part of all our relations. This change must be initiated by Christians: in analysing all our motives and attitudes to ascertain whether any sinful division, any misunderstanding or animosity, any prejudice or fear has tainted our mutual relations as Christians. And where this exists Christians of all Churches and cultures and races dare not be silent or satisfied, but must do everything in their power through words and acts of love, through persistent prayer to illustrate the truth of reconciliation in all our relations towards all fellow Christians. Do we Christians realize and accept this as an individual moral obligation that we dare not shirk whether our church assists us or not? But we also realize that as God's reconciliation has gone out to the world, our witness must also become an outreach to non-Christians? To all those who stand aloof, who are critical or hostile towards Christianity and the Church?

Now I know that you've already said to yourself: this is all very well and true but how do we implement this? Where do we start? And how far do we go? 
With regard to the starting-point, the answer is very simple: there is no reconciliation possible without conversation and communication. As God has started the great conversation with man through Christ, his living Word, so God wishes us to start right here: with a personal encounter of Christian with Christian through speech and prayer about all matters which divide and sever where Christ wishes to unite and join. And always our starting-point will and must be Christ, our Lord - his word, his spirit, his example, his life! The moment we acknowledge this, a central unity of conviction replaces all our lesser loyalties, all our minor differences of culture, politics or race. But if we refuse to act on this basis we not only prove that prejudice, fear or hatred controls our lives but we thereby grieve the Spirit of the living God and immeasurably weaken our Christian witness in the eyes of the world!

There is so much latent goodwill amongst Afrikaans- and English-speaking, white and non-white Christians in South Africa, waiting to be harnessed and channelled to larger aims than the sectional ones which up till now have taken up most of our loyalties and energies. Our changed times and situation call for a larger concept of unity, of common sacrifice and service from all sections to all sections of our multicultural and multiracial country than has up until now been expressed and enacted. But before this could become a glorious reality we must admit frankly and acknowledge in humility and with shame the deep-rooted prejudices of the past still keeping Afrikaans- and English-speaking people apart, as well as the baseless fear of many whites toward non-whites and the senseless hatred of many nonwhites toward whites. We as Christians confess and believe that only in and through Christ can these prejudices, fears and hatreds be broken down and a new mutual trust be built. But before this could materialize there must first be born amongst the Christians of the country a new vision of our spiritual and moral obligations, a new willingness to obey the dictates of a sensitised Christian conscience in all matters touching on righteousness, truth and mercy, and a new preparedness to act more lovingly and sacrificially. Then only will the world regain its faith in the faith we profess!

If, on the other hand, all attempts by Christians to create a better understanding and closer Christian fellowship are discouraged, continually criticized, scoffed at or rejected, if through an increased process of isolation or secret machinations Christians are hindered or prevented from enacting the reconciliation of God in our human relations, it must eventually lead to a state of chaos and anarchy. For where the Christian forces of reconciliation are not allowed to function freely under the leadership of the Holy Spirit, non-Christian forces of retaliation will eventually take over under the leadership of unholy spirits. Where there is little or no communication through contact and consultation on the basis of love and truth, there is no possibility of true communion of mind and spirit. And where true communion is lacking or ailing, a false communion based on a false brotherhood, i.e. Communism, takes over. Therefore, the only adequate answer to all forms and 
possible growth of Communism is for Christians to create a communion and a community of love, mutual understanding and respect that makes it impossible for any of the false doctrines of the Communists to flourish or survive. That is why the final answer of the Christian to the Communist must be the fullness of Life and Love that only Christ can give. All other attempts to combat Communism, however well meant or well-planned, are futile and must eventually fail.

The time has arrived for a new dedication and a new commitment of all Christians of all cultures and races to the cause of the Kingdom of God in South Africa. Too long too many Christians have been silent over too many important issues. For all those who have spoken and acted as Christians in giving their witness lovingly and fearlessly, we humbly thank God. It is here where the Christian Institute has come into being as an added channel, an instrument for conversation, consultation and consecration - so that more opportunities could be created and offered to more Christians of more churches amongst all our cultural and racial groups to come together, to share our faith and our fears, to communicate with one another about the things of the Kingdom, to experience a deeper fellowship and to receive a wider vision of Christ's truth and love in order that all of us individuals may serve Christ better in and through our individual churches for the salvation of the world.

No other power (political, educational, economic or social - however important and necessary such powers may be) can offer any permanent solution to the serious problems we face. Only in and through Christ and his reconciling work can we hope to attain the leadership that God expects of his followers in this crucial hour of our history. But this will only be achieved if we first rediscover our unity in Christ, re-affirm our faith in Him as Lord, and re-dedicate ourselves for every sacrifice that He demands. Then, and then only, will we as Christians be able to give a witness which, through its spiritual and moral strength, will transform the hearts of men and change the destiny of our country.

Christians of South Africa, let us hear and obey! 


\section{A personal journey}

In December 1979 my family and I arrived in the Dutch Reformed congregation of Aasvoëlkop in Johannesburg for an unforgettable ministry of four years. This congregation not only accommodated some very prominent and influential people in the Afrikaner community, but it also became notorious for the fact that it was the last congregation in which Beyers Naudé served as a Dutch Reformed Church minister, before finally leaving to become the first full-time director of the then controversial Christian Institute.

At the time I had not met him personally. As a young student at the University of Stellenbosch I accidentally walked in on a Nusas meeting one evening at the Wilcox Building where Dr Naudé was still conversing with a small group of students after the main gathering. Seeing his pitch-black hair and the energy and the urgency with which he was talking, I could well have imagined that he was the communist and the devil he had been made out to be. In fact at the time I arrived in Johannesburg this so-called "communist devil" and his "pernicious influence" had, according to some, luckily and deservedly been contained - being put under house arrest for several years and later being restricted to the city of Johannesburg.

And now, in 1979, I suddenly found myself moving around in the same surroundings, entering the same spaces where he used to move, meeting the same people whom he had met, sharing the same pastoral experiences he had come to know so well 20 years earlier. From the outset it was clear that the memory of Beyers Naudé and especially the impact of his ministry was still very much alive. In fact, many members of the congregation mentioned that he had been the best minister they had ever had. To support this people referred to his powerful preaching and especially the committed and sensitive way in which he and his wife Ilse had cared for the flock.

The other side of the picture, however, was that the congregation remained puzzled by the strange and dramatic decisions he eventually made. Deep down they did not really understand what motivated someone who was earmarked for the highest position in the church to leave such a place of privilege and opt for the bleak and highly controversial world of the Christian Institute - an organization

1 Tribute to Beyers Naudé delivered at the celebration of his $89^{\text {th }}$ birthday on 31 May 2004 at the Beyers Naudé Centre for Public Theology at the University of Stellenbosch.

2 Dr Carel Anthonissen is minister of the Dutch Reformed Student Church at the University of Stellenbosch and director of the Centre for Christian Spirituality in Cape Town. 
which at the time tried to understand and express the frustrations and aspirations of black people.

Perhaps it was this unresolved mystery, my fascination with this strange contradiction in the mind of the congregation, that made me accept when the Dominican priest, Albert Nolan, having heard of my experiences, asked me one evening at the end of 1982 whether I would like to meet Beyers Naudé. Albert was visiting a mutual friend at our home and Beyers Naudé was still under police surveillance and restricted to the Johannesburg magisterial district.

Aware of the risks and the consequences involved - and they were considerable, given the deep prejudice and even anger that also prevailed in the congregation something deep inside me sensed that this was an opportunity not to be missed; that it was an essential step for the development and broadening of my own theological and political horizons.

And so it happened that on a cool sunny Wednesday morning in November of the same year, I drove off to the Roman Catholic convent in Victory Park at 10h00. Here I was scheduled to meet in secret the so-called devil himself. Looking back today I can still recall the anxiety and the uncertainty created by this venture. It almost felt as if I was part of a James Bond movie, where I was on a secret mission to meet the chief villain himself.

And what a pleasant surprise I got. At the convent, apart from the friendly sisters who all knew Beyers Naudé and welcomed me heartily, I was met by a friendly fatherly figure, dressed in his well-known safari suit and driving an old Peugeot similar to my own. Our first meeting in a small room of the convent was mainly an exploratory discussion in which we became better acquainted, carefully inquiring after and telling the stories of our lives. What impressed me most at the time was Oom Bey's willingness and openness to share his personal history with me as a young, inexperienced minister. He also impressed me by his willingness to answer my often naive questions and the great patience with which he tended to my small concerns and struggles. But slowly, like Jem's discovery in To kill a Mockingbird, when he finally saw who Boo Radley, their one-time foe, really was, I discovered in Beyers Naudé a dear friend and a concerned father, someone to respect and not to fear, someone who, sharing the same roots and tradition, understood my particular journey and was willing to accompany me keenly and joyfully. And of course I was not the only one to whom he played this role during these trying times.

After this initial meeting, which lasted two hours, we agreed to meet regularly each month. As you can imagine these meetings, which usually lasted two hours, became a wonderful journey - a journey that went on till the end of 1983, when I left for Stellenbosch. These meetings changed my life and future ministry in a dramatic fashion. In fact they helped me redefine my calling and placed me on a 
road which at times became extremely difficult, but on which I now look back in wonder and with deep gratitude.

This initial meeting was, of course, also the start of some wonderful personal moments and encounters with Oom Bey and Tannie Ilse. Encounters which not only enriched the life of my family, but which eventually spiralled out to touch, influence and change the lives of many other friends and especially also of a number of students in my students' ministry later on.

Looking back I remember some days in Johannesburg when I came to my post box to discover some book or material that Oom Bey, or some friend acting as courier, had placed there during the night or in the early morning - material he thought might be helpful and interesting to me. I remember visiting him one morning at his home in Greenside with my eldest son and how he beckoned me to follow him to his garden because his phone was tapped and they suspected other recording devices were placed in his house as well. I remember some wonderful, enriching evenings in the company of the Naudés at the homes of some of my younger friends in the congregation to whom I introduced them.

And later, in Stellenbosch, I recall sporadic telephone conversations I had with Oom Bey and Tannie Ilse - one concerning an invitation to be part of a group from the World Council of Churches to meet the so-called Liberation Movement in Harare for the first time; another to attend the celebrations of his eightieth birthday which were held by former staff members of the formerly banned Christian Institute; another from Tannie Ilse to ask whether I would introduce some overseas Christian Fellowship Trust visitors to the Cape and to organizations such as the Rural Foundation. Oom Bey even phoned me once to ask advice and help concerning a Swiss friend's daughter, who became involved with a DRC minister's son. I also remember one evening when they came to visit us at our home in Stellenbosch - how it started to rain and I had to braai the snoek in my garage with him standing by, despite the smoke and the inconvenience. But that was Oom Bey.

Perhaps some of the most significant moments with the Naudé's occurred during the mid-eighties and the early nineties when I accompanied students on several ecumenical tours to Gauteng. These tours became life-changing experiences for most of these students, because for the first time they were exposed to a different side of South African society. In these ventures the Naudés played an enormous role. A visit to their home, usually on an evening where they could meet and discuss openly the problems of the church and the country, became a permanent feature. They were always willing to open their home and their hearts to the young people and support them in their struggles.

I want to assert today that many of those students who are now contributing positively to the future of our country are doing so because they had been part of 
these enlightening and liberating evenings with the Naudés (as with pioneers in other ways, such as Willie Cilliers, Nico Smith, Joop Lensick, Eddie Bruwer, etc.).

But what exactly was Beyers Naudés influence on us during those days and what relevance does it still have for the Dutch Reformed Church today? What is this legacy? What can we still learn from it? There are of course many aspects of his ministry and personal life from which we can learn. I am here only touching on the few that I draw from my own experience with him.

\section{Beyers Naudé's relevance for the DRC}

For me the lives and witnesses of Beyers and Ilse Naudé are today a signpost, almost a living reminder of the crucial ethos and values that need to be part of the life of the church and society today.

1. First of all their lives remind us that we need not be ashamed of our own roots and especially the religious and Reformed tradition in which we grew up. In fact, we should rediscover the wonderful history, the basic intentions of this tradition and find creative and refreshing ways of applying them anew to the realities of our day.

Although the Afrikaner identity became skewed and the Reformed heritage was deformed beyond recognition during the apartheid years, Beyers Naudé not only remained loyal to the Afrikaner community, but also tried to remain close to the basic intention and prophetic ethos of the Reformed tradition.

Everyone who knows Oom Bey and Tannie Ilse knows that, although they were both blessed with various talents of leadership and social skills, in a sense they were just an ordinary traditional Afrikaner couple - people with a deep love of and concern for their own community. They understood the fears and ambitions of the Afrikaner and wanted, above all, to assist them in understanding their real calling in this beautiful country. For this they constantly drew on the heritage of their religion and faith and especially on what they understood as the more authentic version of Reformed theology. For them this meant a deep respect for the Bible as the authoritative Word of God. It also led them to understand, in an almost childlike way, that the basic message of the Bible is one of grace, compassion and justice for all people and that this message has to be faithfully and uncompromisingly proclaimed and practised in an unjust society. It was exactly this understanding of the Bible and the life-changing choices it brought about that made them warriors for justice and the respected people they are today.

Tragically, very little of this spiritual ethos with its bearing on public life is visible today in the Dutch Reformed Church and especially amongst the youth. In fact, one of the surprising and even unexpected things that happened after 1994 is that many amongst the latter in the Dutch Reformed Church turned their backs on the church. Recent research shows that up to $28 \%$ of students leave the Dutch 
Reformed Church once they arrive on campus. Given the way the Dutch Reformed Church has erred and misled its own members over the years, teaching them that apartheid was a biblical notion, perhaps this trend or development could have been anticipated.

Still, many of us who were inspired by and gained hope through the brave prophetic choices that were made by people like Beyers Naudé - and there were many others as well - and who, through them, discovered the unique nourishment and enrichment of the ecumenical church and its confessional documents, indeed expected something else. We expected that the white community and especially its youth would proudly take ownership and would honour this legacy as a crucial part of their history and their Reformed heritage; that they would bravely take up the challenges it offered.

Instead one has the impression that this rich history, so full of hope and heroism, has not only been overlooked by many, but has either left them cold or is seen as an uncomfortable burden which they are reluctant to embrace as a precious part of their own history. Worse still, one has the impression that many white Christians today have chosen for a kind of copout, not only leaving the church, but embracing a spirituality that is more tuned towards their immediate material and emotional needs and the products of a market-driven economy than to the radical biblical message. This message is one that often only brings healing through judgement, honest self-examination and contrition. A serious question confronting the Dutch Reformed Church today concerns its theology and the practical organization of its ministry. It relates to whether the church is going to play along with these shortterm, and in many instances artificial, needs of the masses, trying to address and fulfil them, or whether it is willing to honour and creatively reclaim the prophetic heritage of people like Beyers Naudé. This heritage is characterized by a singleminded obedience and a firm commitment to the public sphere.

2. The history of Beyers Naudé is, however, also a reminder not to be afraid to cross unexplored boundaries and to move into dangerous regions. Even more to the point, we should not allow fear or comfort to dictate and control our actions, but we should bravely do what is right.

It is a well documented fact that the one thing that helped Beyers Naudé to discover the deeper tenets of his own tradition, and therefore also the basic message of the Bible for his immediate context in the harrowing years of apartheid, was not, in the first place, an academic inquiry. Instead it was the first-hand exposure to the harsh conditions under which missionaries in the Potchefstroom area worked, together with their stories about the poverty and injustices that surrounded them every day. This forced Beyers to undertake a new and thorough study of the biblical grounds for the apartheid system. Even more so, it became a haunting memory, a burden on his conscience that he was unable to shake off and 
which eventually gave him the courage to venture fearlessly and with only his faith as a guiding light into new territory.

Of course this guiding faith was never a blind opportunistic choice for Beyers Naudé. It was motivated by the intuitive trust that crossing these new and even dangerous frontiers did not necessarily bring about loss. On the contrary, although it took him away from the more secure and comfortable spaces of his life into the insecure world of the struggle, it also contained the promise of new discoveries, new insights, new opportunities and especially of meeting new people - people from whom he learnt the value of a common humanity and through whom he gained hope for the future.

I may be mistaken, but I have the impression that the Dutch Reformed Church and especially contemporary leaders do not really understand these, what I want to call, surprises or even ecstasies of the fringes - the enlightenment and even wonder that occurs only when you leave your comfort zone and, in the words of Bonhoeffer, dare to do something brave and unconventional. In this regard I believe that especially one issue has become an important test for the Dutch Reformed Church's credibility and its willingness to venture bravely into unknown territory. This issue is the controversial and highly emotional 'gay issue'. During the past five years I have been participating in research aimed at helping the church review her present policy on the issue. Mainly as a result of this I have also had the privilege to meet and pastorally accompany numerous gay people and their families. In this process I have been deeply touched by their struggles, their hurt and especially their anger at and frustration with the church. My honest impression is that the church and its leadership do not really understand or listen to the urgency of their plight. This becomes clear in the fact that, despite numerous pleas and debates, addressing the gay issue is still not considered a priority on the church's agenda. What is more, one cannot escape the feeling that, for fear of a division in what is perceived to be the core constituency, the leadership also lacks the courage and the faith to bravely confess their insensitivity and mistakes in this regard and without qualification to accept gay people as people who have also been created in the image of God.

3. Beyers Naudé's history finally reminds us not to fear our own vulnerability and shameful histories. In fact, his life invites us to discover that the more meaningful things in history sometimes do not happen through glamorous events or impressive strategies or displays of power, but in silent obscure ways, in the wilderness, in the desert - that true leadership should at times be prepared to take and assist us there.

George Eliot articulated this perspective in a gripping way in her highly acclaimed novel Middlemarch: 
"That things are not so ill with you and me as they might have been is half owing to the number who lived faithfully a hidden life, and rest in unvisited tombs."

Beyers Naudé's life is living proof of this profound and very important truth. The remarkable thing about his years under house arrest was that, contrary to the plan of the government and his enemies to eliminate or at least neutralise his influence, he or his ministry did not slip into oblivion. Instead, his years of solitude and confinement became, in his own words, one of the most fruitful and exciting times in his ministry - a time in which he was offered the unexpected opportunity to give hope to thousands of black people without hope in this country. It was also in this time, ironically, that his status and integrity as a major Christian witness was internationally established. Of all the people whom the different delegations from different churches worldwide met during the apartheid years, Beyers Naudé was the one who was listened to and whose opinion and analysis of the situation made a lasting impression. That happened notwithstanding the fact that at the time he was in the proverbial wilderness.

It is my belief that this remains one of the big challenges for the Dutch Reformed Church and the church as a whole. Metaphorically speaking, the church in South Africa, and specifically the Dutch Reformed Church, is currently living in or moving through a desert period. Having lost its former position of power and influence, it has become smaller, more marginal and it feels itself extremely vulnerable, even struggling to regain a clear identity. The biggest mistake the church can make in such a time is to deny this, or see it as an embarrassment. For one's own healing and growth one should not try to put this right superficially or to gloss over difficulties too quickly and too easily. Again there are signs that the church, her members and leaders, are tempted to do exactly this - either by longing back to the old days of bondage when power and privilege were relative but prevalent, or by entering too soon into the new comforts and power alliances of the promised land. The big challenge for the Dutch Reformed Church today is not to yield to these temptations but to boldly and joyfully embrace its relative isolation and weakness, its experience of the so-called wilderness, as a God-given opportunity. This can become a place where God, as in the Old Testament, can start again to renew his church in unexpected ways, bringing it back to where it needs to be.

In the Old Testament the desert was not primarily a place of despair and hopelessness, of pure survival and endurance, but a place of hope and renewal, a place of unexpected surprises. It was a place where you had to learn to look more closely, live more sensitively, slowly discovering and appreciating the theophanic qualities of silence, solitude, simplicity and even poverty. Here you are called to journey without too much baggage, totally dependent on the daily care and provision of God himself. It is a place where you have to prepare yourself for new 
tasks and challenges - tasks that you have not strategically planned or managed or manipulated, but which God has gradually revealed to you, mostly in community with those travelling on the same road, sharing the same experiences.

What the church now needs are leaders who can lead them, not only though the desert, but in the desert. Leaders now should be deeply sceptical of, even untouchable by, the allure of power and control. Like Beyers Naudé, they should be willing to embrace their vulnerability as a unique opportunity, perhaps the only opportunity, to be blessed. The crucial question is: have the leaders got the courage, the capacity and the experience to do this? Have we got leaders with this kind of courage at all?

I conclude with the following poem, in Afrikaans, which I have written in gratitude for Oom Bey and his lasting influence on my own life.

\section{Oom Bey}

so bonkig soos Rebunie staan jy as baken langs my pad 'n stoere wink dat eensaamheid ook vryheid is; dat donkerte 'n nagwaak spel; dat die geskiedenis die vaandeldraer dalk mag kroon, en God selfs meer reëel in goiing en in blikbekers kan woon.

inderdaad: jy't my gedoop met vuur, met sout en fyn salpeter ingelyf 
Right at the start of the preamble to our country's constitution one finds Article 1 of Part 1 which reads: "The people of the Union acknowledge the sovereignty and guidance of Almighty God."

Legislation in our country furthermore stipulates that every white person above 18 years shall have the right to vote. Both morality and democracy find expression here, therefore, and every white inhabitant of the country at least is thereby confronted with a right and a duty: the right to participate directly in the government of the state (especially as revealed in the decisions of our Parliament) and the duty to see to it that the legislation of the state fulfils the Christian demands of righteousness and neighbourly love.

Precisely for this reason is it the right, privilege and duty of every white citizen to follow and to adjust with critical responsibility the deliberations of our two highest legislative assemblies. Being a Christian and being a citizen impose upon one the duty, firstly, to acquaint oneself with all available information concerning debates and decisions in the House of Assembly as well as in the Senate. To be able to do so effectively requires the reading of newspapers and publications and listening to opinions representing all political viewpoints. He who does not do this has no right to join the discussion - or to vote. But secondly, they entail the positing as principle (at least for all who call themselves Christians) that Christian standards and values shall always control political interests. Christian principles must determine political policy - not vice versa.

If we refuse to accept this, and to practise it, Art. 1 or any reference to God or the Almighty must be expunged from our constitution. And even if this were to happen (which is almost unthinkable), it would still remain the duty of every Christian (specifically of those who have to vote) to give precedence to the Christian requirements of righteousness, truth and neighbourliness above all party loyalty. It is on this very point that every religious denomination in South Africa bears a great moral responsibility: to test all political events and decisions according to the demands of Christian morality and to give public expression to its views - including its critical views. The church which does not do so is neglecting its duty as church and as educator of the thought and norms (also, therefore, the political norms) of its members.

1 Article published in Pro Veritate, 15 February 1969, 2-3. 
This responsibility which rests on every church and on every white voter becomes so much bigger because by far the largest part of our population have no say whatsoever in the decisions of Parliament. The whites have deprived them of this right and have thereby accepted a principle of injustice which runs counter to all Christian righteousness. By this very injustice a double responsibility, a grave duty has been laid on the shoulders of the white rulers to perform their task with greater circumspection. And when, furthermore, the conscience of the people becomes blunted to obvious injustice perpetrated against millions of inhabitants of the country (apart from all the good that is being done), every Christian must do his duty as citizen with double vigilance, make his voice herald (also his protest, therefore, when necessary) and fulfil his political task. To do this effectively, he has the right - and the duty - to ask his church that it should assist him in this highly responsible task. And only such a church or churches as are prepared to place the Biblical requirements of righteousness, neighbourly love and truth above all political servility, are able to perform this service towards their members. Thus and only thus - does the Church do justice to its calling as regards the people. 


\section{Introduction}

Recently, when colleague Hannes Adonis saw the photograph printed on the then proposed cover of this publication - Dr Beyers Naudé in his pastoral cloak and Bible in his hand in front of a Casspir army vehicle during the years of the struggle against apartheid - he pointed at the image and exclaimed with childlike excitement: "This is how he is!" (Dís soos hy is!).

Adonis, who has also contributed to this publication, participated for many years with Oom Bey in the struggle against apartheid. He knows who Oom Bey was; he knows how Oom Bey was. He could instinctively and intuitively recognize his old friend and comrade. Adonis used the language of character and virtue to describe Oom Bey.

In ethical discourse the themes of virtue and character have received increased attention over the last three decades. There is growing recognition of the fact that the moral life cannot be adequately described in terms of categories like choices, decisions, behaviour and conduct which can be formulated and achieved in an autonomous, individualistic and rational way. Therefore, it has been suggested that, for a fuller understanding of the moral life, attention should also be given to moral agents as well as the internal (emotions, desires, attitudes, etc.) and external (the narratives, role models and various practices of communities) factors which impact on and form these moral agents. The latter approach, which also focuses on the so-called "being aspects" - as opposed to a sole emphasis on the "acting aspects" of the moral life - is called the narrative, character, or virtue approach to ethics. Some would even describe it as the post-liberal approach to ethics, since postliberal thinkers from various disciplines such as Martha Nussbaum, Iris Murdoch, Zygmund Bauman, Alisdair MacIntyre, Charles Taylor, Stanley Hauerwas, Reinhold Hütter and Arne Rasmusson advance this approach. ${ }^{2}$

Besides the use of concepts like "character" and "virtue" to describe a specific approach to morality and ethics, these words are also used to describe the moral life of a person. In the rest of this article character and virtue will be used in the latter meaning. From the description it will become clear that, although these two

1 Nico Koopman is professor of Christian Ethics and head of the Department of Systematic Theology and Ecclesiology at the University of Stellenbosch. He is also the director of the Beyers Naudé Centre for Public Theology.

2 For a helpful discussion on virtue ethics see, amongst others, Koopman N and Vosloo R (2002: 6076), Hauerwas and Pinches (1997), Bacon. Pettit and Slote (1999). 
terms are distinguishable, they are not to be separated as categories to describe people who strive towards living morally good lives.

Character and virtue will be described, after which some remarks will be made on acquiring them. Finally, I shall attempt to demonstrate how Oom Bey exemplified character and virtue in his life, work and person.

\section{On character}

The American theologian, Stanley Hauerwas, gives a helpful description of character in identifying various ways in which we speak about it.

Character refers to the moral traits and features of people. It refers to the typical way in which a person carries out his or her tasks, e.g. in a perfectionist way (1974: 53; 1975: 14). Secondly, character refers to the peculiar style of a person in terms of which his or her behaviour is measured. Psychiatrists are especially interested in this second use of character (1975: 14). In the third place, character refers to the peculiar, and often humoristic, style of a person in terms of which they can be distinguished from others (1975: 14). Character, in a fourth instance, means that one "has character". Hauerwas prefers the latter use of the term character. ${ }^{3}$ To "have character" does not only refer to individual traits, but to the fact that in everything one does people can see there is control, consistency, direction, firmness of principles, integrity, incorruptibility and reliability (1974: 53, 55; 1975: 14-16). Therefore, character is not only a term that is employed to distinguish one person from another. It also demonstrates the intentional, purposeful, conscious way in which a person strives to be different to the way he or she is by nature (1974: 52). The way a person chooses to satisfy his or her inclinations and desires reflects his or her character (1974: 52-53). This description by Hauerwas will also help us to understand that a person of character embodies the different virtues that will be outlined in the next section of this paper. In the person who has character these virtues are all integrated. They are, in a sense, different expressions of one's character. In the words of Adonis: they say who and how we are. In the description of Beyers Naudé as a person of character the last three of Hauerwas's meanings of the word will apply.

According to American theologians Bruce Birch and Larry Rasmussen (1989: 124), an etymological study of the word character indicates that character has to do with the engraving of particular principles into a person. The Greek root of the word refers to an engraving tool and, by extension, to the marks made by it. Hence, character encompasses the notion of values that are engraved into a person, over

3 Hauerwas (1975: 21) defines character as follows: "Character is not an accidental feature of our lives that can be distinguished from 'what we really are'; rather character is a concept that denotes what makes us determinative moral agents. Our character is not a shadow of some deeper but more hidden real self; it is the form of our agency acquired through our beliefs and actions." 
time, so that it becomes assimilated, incarnated, and embodied in the person. Therefore, character, like the virtues, develops over time in communion with God and other human beings.

\section{On virtue}

Another North American, the ethicist J. Philip Wogaman (1989: 29), provides a valuable description of virtue. He describes it as "a disposition of the will towards a good end, as a tendency to think or behave in accordance with goodness, as a habit of the will to overcome a threat to our ultimate good". A virtue is a predisposition, a tendency, an intuition to be and to act in a specific way without prior reflection. It almost happens instinctively. To some extent, it has an element of unavoidability.

The Greek word for virtue, arête, refers to the divine power that we have to be and to act in accordance with goodness. ${ }^{4}$ Virtue also has the dimension of habitus. This implies that virtue is acquired in a process of consistent and collective habitual behaviour. (In section 4 of this essay there will be further comments on the formation of virtue and character.)

The Greek philosopher Aristotle identified four so-called cardinal virtues. "Cardinal" is derived from the Latin word cardo, which refers to the hinge of a door. Therefore, the four cardinal virtues form the hinge on which all virtues turn. These virtues are justice, moderation/self-control, discernment/wisdom and courage/fortitude. Centuries later Thomas Aquinas added three theological virtues to these four, namely faith, hope and love. ${ }^{5}$

The following brief discussion of these virtues will assist in the attempt to describe Oom Bey as a person of virtue and character.

\subsection{On Justice}

Just persons do not only adhere objectively to justice as a moral value that guides private and public life. For them justice is an embodied, incarnated value which almost intuitively guides their way of being, living, deciding and acting in this world.

Virtuous individuals embody the various descriptions of justice that their societies strive to adhere to. Utilitarian theories of justice envisage a just society as one where the greatest good is achieved for the benefit of the greatest number of people. Communitarian theories of justice reckon that solidarity opens the doors to justice. Egalitarian theories plead for equal access to the most basic goods for all

4 Dutch theologian, Johannes van der Ven, refers to various normative distinctions to evaluate the moral life (1998: 1-10): purposive, good and right; good, right and wise.

5 For a discussion of these seven virtues and how they were related to the seven deadly sins, as well as for a feminist critique of both the virtues and deadly sins, see Capps D (1987). 
people. Libertarian theories stress freedom, especially the freedom of the individual, to develop potentialities as the way towards justice. ${ }^{6}$

In a study conducted by Christian ethicist Karin Lebacqz, she analyses various theories of justice. These include the emphasis placed by Liberation Theology on the priority of the poor and vulnerable in any discourse on justice and the famous letter of 1986 by the Conference of American Catholic Bishops on the quest for economic justice. The latter pleaded, amongst other things, for the equal distribution of goods especially to the poor. Lebacqz also pleads on behalf of the poor and vulnerable, but specifically for attention to be paid to their narratives and for this to receive epistemological preference in discourses on justice. ${ }^{7} \mathrm{I}$, amongst others, have pleaded in an appeal based on the meaning of the Hebrew words for justice, mishpat and tsedaqah, for an understanding of justice as compassionate justice and restorative justice, which entails both forensic/juridical as well as sacrificial justice. ${ }^{8}$ This understanding of justice includes, but also goes beyond, retributive, distributive and rehabilitative justice.

\subsection{On Temperance}

Temperance, from the Latin temperantia, literally means the right measure, or the right order. Therefore, temperance is a virtue which indicates that one guards against the excessive use of goods. Simultaneously it implies guarding against the insufficient use of goods. This quest for the right measure or order does not only have to do with material or bodily goods. In fact, in all facets of life the temperate person strives for the right order or measure. ${ }^{9}$

With an appeal to Thomas Aquinas, Dutch ethicist Paul van Tongeren (2003: 109111) clarifies the different dimensions of temperance. Shame (verecundia) is the fear of a shameful act; honesty (honestas) is the appropriate and not lustful enjoyment of goods; abstinence (abstinentia) is the joyful quest for the right measure for the sake of the good life and the kingdom of God. Van Tongeren (ibid, 109) phrases this is follows: "Wie niet lachend het goede doet, die is op zijn best een beginner. Ook als milieuactivist moet je soms in de spiegel kijken". ${ }^{10}$ Sobriety (sobrietas), according to Van Tongeren, was for Thomas Aquinas the quest to find the right measure regarding the use of wine, while chastity (castitas) was the rational quest for the right measure regarding sexual desire - directly related to this is virginity (virginitas), the quest for the right measure in sexual matters for the sake of the good life. Anger and protest activities are to be accompanied by mildness

\footnotetext{
6 For a helpful analysis of these theories of justice, see Beauchamp and Childress (2003).

7 See Lebacqz $(1986 ; 1987 ; 1994)$.

$8 \quad$ See Lebacqz (1986, 1987 and 1994), Koopman (publication forthcoming) and, for another portrayal of justice as compassionate justice, Meyer (2000).

9 Compare the Afrikaans word for temperance, matigheid, which can be rendered as maat-tigheid to express that we seek for the right measure (maat) in everything.

10 For a depiction of ethics as feast, see G Rothuizen (1973: 171-194).
} 
(clementia) and tenderness or meekness (mansuetudo). Finally, Aquinas viewed modesty (modestia), willingness to learn (studiositas) and humility (humilitas) as dimensions of temperance that oppose pride (superbia and hybris).

Virtuous living for Christians is the quest for this right measure in all relationships and in all facets of life in the light of God's Word and the other sources of morality of the Christian tradition.

\subsection{On prudence/discernment/wisdom}

People with discernment are capable of distinguishing between right and wrong, good and bad, holy and unholy, faithfulness and unfaithfulness to God, obedience and disobedience to His Word and will. In a modern/post-modern, "glocalised" (i.e. the global and the local impacting on each other) world, where there are a multitude of choices between a multitude of options, people need wisdom and discernment.

Moreover, in a tragic world where there are many aporias, dead-end streets, the need for wise and prudent people is even greater. In such an aporetic ${ }^{11}$ world the choice is not always between right and wrong, but between more wrong and less wrong, and more right and less right. Sometimes we have to be able to prioritise, to discern what and who requires attention at this specific point in time. Because discernment entails that we sometimes have to choose for the lesser of two or more evils, we have to do so not with concession, but with confession. We make these choices knowing that we did not live up to the ideal, that we did not have a concession to do so. We know that, even though the choice was unpreventable and, even though it is the least evil of all possibilities, it remains evil. Therefore, we make this type of choice with a confession of guilt and pain.

Bonhoeffer (1995: 50 -51) also emphasizes the importance of discerning the things that really matter, to perceive the essential nature of things, to see into the depth of things, to see reality as it is. To achieve this, the multiplicity of knowledge of the world is helpful, but not essential. In fact, the person best informed is not necessarily the wisest person. Although knowledge of trivial detail sometimes might help to see into the depth of things, we are not dependent upon it. To achieve this wisdom that sees into the depth of things, we need simplicity.

"To be simple is to fix one's eye solely on the simple truth of God at a time when all concepts are being confused, distorted or turned upside-down. It is to be single-hearted, and not a man [sic] of two souls, ... (Jas. 1.8). Because the simple man knows God, because God is his, he clings to the commandments, judgements and the mercies which come from God's mouth every day afresh. Not fettered by principles, but bound by love for God, he has been set free from the

11 For a description of the aporetic nature of existence, see Bauman (1993: 8). 
problems and conflicts of ethical decision. They no longer oppress him. He belongs simply and solely to God and to the will of God. It is precisely because he looks only to God, without any sidelong glance at the world, that he is able to look at the reality of the world freely and without prejudice. And that is how simplicity becomes wisdom" (Bonhoeffer 1995: 50).

\subsection{On courage/fortitude}

Stanley Hauerwas and Charles Pinches (1997: 149-165) share some helpful insights on courage. They analyse the views of Aristotle and Aquinas on courage. According to the former, courage entails the conquering of fear, especially the fear of a noble death. For him death in battle is a noble death. To have courage is to be willing to die in battle. Hauerwas and Pinches appreciate Aquinas's idea that the noble death that we should not fear is death by martyrdom and persecution. Based on this, they argue that death in battle suggests that we use the same means as our enemies. This life-destructive orientation does not bring hope to the world. On the other hand, those who die a martyr's death do not use life-destructive means. They have the confidence that God will complete the work that He has begun in them even if their enemies take their lives. Moreover, they have not merely the victory of the nation and the common good as their telos (goal), but the friendship of all with God, of which a life of dignity forms an important ingredient. The extraordinary death through persecution also shows how martyrs are committed to a life of sacrifice throughout their lives, in all daily acts and practices, for the sake of friendship of all with God.

Courage is demonstrated in extraordinary circumstances, like in the opposition to Nazism and apartheid. But it is also, perhaps even mostly, required in the so-called ordinary events and challenges of every day, like paying attention to the plight of family members and friends and those outside one's immediate circle. It is required when a moral "no" is necessary, even though everyone else is saying "yes". These courageous people, moral heroes, are called for, not only when extraordinary challenges are faced, but also when we deal with the seemingly ordinary challenges of daily life.

The explanation of courage up to now makes it clear that courage does not only entail concrete and active engagement, but also endurance. In this sense courage is related to patience. Hauerwas and Pinches (1997: 175-176) reckon patience is the most neglected virtue in modern societies, in which the levels of addiction to hyperactivity are very high. Where people are aware of the presence and involvement of God in the world, they oppose the impatience of Eve and Adam which made them break God's commandment, the impatience of Cain which made him the killer instead of the keeper of his brother, and the impatience which makes us desert our suffering brothers and sisters, because we impatiently reckon that if we cannot immediately cure we can also not patiently care. 


\subsection{Faith}

Faith is one of the three theological virtues that Thomas Aquinas formulated - the other two are hope and love.

Augustine's classic explanation of faith remains helpful to understand what it entails and what the person is like who embodies faith. The famous Faith and Order document, Confessing the one faith, of the World Council of Churches, articulates Augustine's threefold definition of faith as believing that God exists (credere Deum), believing God (credere Deo) and believing in God (credere in Deum). Faith, therefore, entails a rational acceptance of God's existence, seriousness about his Word, and trust, submission, dedication, commitment and obedience to Him.

The believing person, however, also distinguishes between the act of believing (fides qua) and the content of the faith (fides quae). Rest, assurance and victory do not reside in the fact that we believe, but in the triune God in Whom we believe. Therefore, we can say that we are not always sure whether we believe, and whether we believe well enough, but we are always sure in Whom we believe. Bonhoeffer (1995: 99) describes this distinction between fides qua and fides quae in the following a remarkable way:

"A life is not justified by love or by hope, but only by faith. For indeed faith alone sets life upon a new foundation, and it is this new foundation alone that justifies my being able to live before God. This foundation is the life, the death and the resurrection of the Lord Jesus Christ ... And faith means the finding and holding fast of this foundation. It means casting anchor upon it and being held fast by it ... Faith is a passive submission to an action, and in this submission alone it is itself an action ... But faith is never alone ... It would be a false faith, a dissembling faith, a hypocritical and self-invented faith such as can never justify, if it were not accompanied by love and hope."

\subsection{Hope}

Over decades Jürgen Moltmann has helped us to understand Christian hope. He describes hope as hope in God for the resurrection and eternal life of human people, for the renewal of the human and non-human world, and for the joyous actualisation and fulfilment of God's glory. For him hope is both personal and cosmic. Eschatology is individual and universal eschatology. God, His glory and His kingdom, is the centre of hope is God (1996: xv-xvi).

Hope, according to Hauerwas and Pinches (1997: 175) is not tempered optimism as:

"... there is a kind of tempered optimism in which people 'either rest too confidently on their past experiences of overcoming dejection or 
manifest a phlegmatic or unreflected disposition at inappropriate times. Their optimism, then, reflects a flawed hope that is close to dullness or presumption. It displays an intemperate attitude that expresses itself in the naïve belief that all will turn out for the best.' Christians have no such wane hope, sustained as we are by a patience that looks to our misfortunes, even the misfortune of our illness and death, as part of our service to one another as God's people."

Christian hope opens the doors for action in the world. Hope and action are intimately related. Hope goes over into action and sustains and guides action. Action is engaged in a hopeful manner. Whilst focusing on the ultimate and perfect, we opt in the meantime for the penultimate and approximate (cf. Bosch 1997: 510). Russel Botman (2001: 80) describes hope in action in the following remarkable way:

"When the scientist works with conscience to find a cure for cancer, we see God's mission as hope in action. When people call for the forgiveness of the debt of "the third world countries", we see God's mission as hope in action. When an investor from North America conducts business as if the children in Africa are his or her own, we see God's mission as hope in action. When a Cuban doctor goes to the poor villages of South Africa to reduce the infant mortality rate, we see God's mission as hope in action. When a person in sub-Saharan Africa is trained to care for people living with HIV-AIDS, we see God's mission as hope in action. When a church opens its heart to the homeless, we see God's mission as hope in action. When subjugated cultures find their way back into the church, we see Gods' mission as hope in action. When communities opt for reconciliation instead of civil war, we see God's mission as hope in action ... I know you want to stop me here, saying, 'But these things are already happening.' I answer, 'Precisely, my argument as well'."

\subsection{Love}

Augustine and Aquinas used the word caritas for love, and viewed love as the heart of all virtues. Augustine viewed the four cardinal virtues as four forms of love that seek to honour God. Temperance is love that implies complete surrender to God; courage is love that tolerates everything with joy for the sake of God; justice is love that serves God alone and therefore operates fairly to all; wisdom is love that discerns those things that either build or break our relationships with God. All virtue and morality rest on love. Our mores are informed by amores (cf. Koopman and Vosloo 2002: 69-70). For Aquinas charity is the mother of all virtues. Charity has a generative function that animates all successive acts of virtue (cf. Keenan 2002: 84). 
Bonhoeffer argues that we learn about love in the person of Jesus Christ. The emphasis should not be on the loving acts of Christ, but on his loving being. "Love is not what He does and what He suffers, but it is what He does and what He suffers. Love is always He Himself. Love is always God Himself. Love is always the revelation of God in Jesus Christ" (1995: 35).

Bonhoeffer continues that there is no distinction to be drawn between the love of Christ and the love of Christians (ibid., 36). There is only one love, namely the love of God in Christ. The love of humans is nothing other than the love of Christ. With regard to love humans are always passive.

"And so love is something which happens to man [sic], something passive, something over which he does not himself dispose, simply because it lies beyond his existence in disunion. Love means the undergoing of the transformation of one's entire existence by God; it means being drawn in into the world as it lives and must live before God and in God. Love, therefore, is not man's choice, but it is the election of man by God." (ibid.).

However, Bonhoeffer also cautions that this passivity should not be understood as inactivity:

"Being loved by God does not by any means deprive man [sic] of his mighty thoughts and his spirited deeds. It is as whole men, as men who think and who act, that we are loved by God and reconciled with God in Christ. And it is as whole men, who think and who act, that we love God and our brothers" (ibid., 37).

\section{On the formation of people of virtue and character}

We become people of virtue and character in communion with God and in communion with the church, i.e. the community of believers. In this twofold communion we are transformed into people who increasingly conform to Jesus Christ (cf. Berkhof 1979: 445; Bonhoeffer, 1995: 60-68).

Humans who are created in the image of God, and whosoever have sinned are transformed into a new creation, into works of art, into God's masterpieces, so that they can do the good works for which he has created them. We are renewed, not because of good works, but by the grace of God and for good works (cf. Ephesians 2:1-10, especially 8-10). God declares us just through the redemptive work of Christ to which we respond with faith. And through the ongoing work of the Holy Spirit we are renewed and transformed in the process of sanctification.

God transforms us personally and individually. However, He also fulfils this act of moral transformation in us in the midst of a congregation that is part of the broader denominational and ecumenical church, and that gathers in transforming 
worship services. The congregation provides room for practices, communal, consistent, collective, coordinated activities which help to actualise in us the good inherent to those practices, e.g. hospitality, friendships, witness and care. The fact that the triune God is carrying out the task of character and moral formation does not exclude human activities like active participation in church life as just described, and the use of knowledge from various disciplines to stand in service of this renewal process..$^{12}$

\section{Beyers Naudé - man of virtue and character}

In his life Beyers Naudé, as a person who lived in communion with God and his church, embodied the above virtues. It is from the outset important to note that Naudé convincingly demonstrated that virtue and character do not stand in the service of a privatist and isolationist ethic. He was indeed not the person of private virtuousness against whom Bonhoeffer warns us:

"Such a man [sic] does not steal. He does not commit murder. He does not commit adultery. Within the limit of his powers he does good. But in his voluntary renunciation of publicity he knows how to remain punctiliously within the permitted bounds which preserve him from involvement in conflict. He must be blind and deaf to the wrongs which surround him. It is only at the price of an act of self-deception that he can safeguard his private blamelessness against contamination through responsible action in the world" (1995: 49).

The character and virtuousness of Beyers Naudé was expressed in private and public life. It was demonstrated in responsible and hazardous action in the world. In various works that had been written in his honour ${ }^{13}$, like this particular publication, people acknowledged this fact. I cannot possibly mention all instances of explicit or implicit reference by various contributors in this book to Oom Bey's character and virtues, but will name a few as illustrations of this fact.

Margaret Nash (p. 36) reminded us that Oom Bey was a man of discernment. When he joined the $\mathrm{CI}$ as its director, "[h]e had to choose between working with a small committed body of people comprising the Christian Institute, which would take action on issues of injustice based on true biblical principles, or a bright career in the church hierarchy." John de Gruchy testifies to this discernment in his

12 With the help of disciplines such as education, psychology, sociology and philosophy Dutch theologian, Hans van der Ven (1998) formulated seven very helpful modes of moral formation, namely discipline, socialisation, value transmission, moral development, value clarification, emotional formation and character formation.

13 Some of the works written in honour of Oom Bey are those edited by Randall (1982), Berkhof (1985), Villa-Vicencio and De Gruchy (1985), and Villa-Vicencio and Niehaus (1995). 
statement that Beyers Naudé could distinguish between true and false patriotism. ${ }^{14}$ Allan Boesak (p. 134) went as far as saying that:

“...once you have met him [Oom Bey], and once you did open your mind and your heart to him and to what he said to you as you spoke with him, you found that you had to make some serious choices about yourself, about your ministry, your way of understanding others and about the issues of justice and peace. You had to make choices about apartheid, the church and about the world in which we live, and ultimately, about the Gospel."

I believe that part of the legacy of Oom Bey is the fact that we can draw on his example of discernment, especially in light of Archbishop Ndungane's remark in the foreword to this book (p. 5) that "[w]e are at the stage in our country where all of us also need to address questions of true patriotism and false patriotism."

We also read accounts of how Oom Bey's virtues of faith, hope, perseverance and courage were also severely tested by events in his life. Constant surveillance by the security forces, being ostracised by the Afrikaner community and the emotional pain it caused him, ${ }^{15}$ the infamous Schlebusch Commission of Inquiry and Oom Bey's refusal to testify before it for which he was eventually prosecuted in court, the eventual banning of the CI and his own seven-year banning from 1977, to name but a few. Despite these gruelling events Oom Bey stood by his convictions. An example of this was when Oom Bey and five other DRC delegates were summoned to appear before the 1961 Transvaal Synod of the DRC to account for their support of the Cottesloe Declaration. Oom Bey was the only one who did not recant. Christoff Pauw wrote of this event and also of Oom Bey's recalling of it years later when he said:

"I had to decide - would I because of pressure, political pressure and other pressures which were being exercised, give in and accept, or would I stand by my convictions which over a period of years had become rooted in me as firm and holy Christian convictions? I decided on the latter course ... I could not see my way clear to giving way on a single one of [the Cottesloe] resolutions, because I was convinced that they were

14 John de Gruchy's statement in his article (p. 86) that " $[t]$ here is a false patriotism which is simply saying yes, yes, yes to everything that the government does", coincides with Oom Bey's moral heroism and courage, which implies his moral "no" when most people around him were saying "yes".

15 Here Martin Rumscheid's recalling of Oom Bey's words in his televised conversation with Dorothee Sölle as he reflected on the injustices of apartheid comes to mind (p. 108-109): "And you know, I must feel the agony of this because I know that the people who are in control and in power doing this, these are my people. I cannot deny that I am an Afrikaner. I don't want to deny it. How can I? I am nothing else but an Afrikaner, and yet in that sense I don't see myself to be there - then the agony of that separation." 
in accordance with the truth of the gospel (Ryan 1990: 66, in Pauw's article, p. 14)."

Denise Ackermann (p. 74) also gave a beautiful summary of the moral fibre of Oom Bey in her contribution:

"Whatever it is that confers moral authority on a human being who is willing to suffer for her or his beliefs, who identifies with the suffering of others in visible and practical ways, who is prepared to face alienation from her or his own community, and who is quite clearly a person whose actions and thoughts are undergirded by profound faith, Beyers Naudé possessed this. Above all he was a person of extraordinary humility. He had an almost childlike acceptance of and belief in the ultimate goodness of humanity. Self-effacing, open and always hopeful, Beyers Naudé gained a moral stature rare in these times."

Besides those tributes to Oom Bey contained in this book, other people from different walks of life, backgrounds, cultures, ethnicities and faith orientations, testified to the virtuous life of this remarkable man. As an example I recall the elaboration on these virtues by Russel Botman, the president of the South African Council of Churches and founder of the Beyers Naudé Centre for Public Theology, at a memorial service in honour of Oom Bey on 18 September 2004. For Botman Oom Bey was:

"a man of true courage, with the courage to stand up to his enemies, and the courage to stand up, whenever it was necessary, to his own associates and his own people, and he had the courage to resist public pressure as well as private greed. Second, he was truly a man of judgement, with perceptive judgement of the future as well as the past, of his own mistakes as well as the mistakes of others, with enough wisdom to act on his judgements. Third, he was also a man of integrity who never ran out on either the principles in which he believed or the people who believed in him. Above all, he was one of those who could not be diverted from his sacred duty and obedience, neither by financial gain nor political and ecclesial ambition. Finally, he was a man of dedication. He was truly a man of dedication with an honour mortgaged to no single human being or group, and compromised by no private obligation or aim, but devoted solely to serving the public good and the interest of justice in obedience to God. Courage, judgement, integrity and dedication - these are the historic qualities of Beyers Naudé, the man who warmed the earth for a very brief time. As the Bible would state it: Beyers Naudé was a good man, full of the Holy Spirit and faith." 
Botman's description aptly portrays Beyers Naudé as the man of virtue and character as outlined in the virtue and character tradition of centuries of ethical discourse.

Beyers Naudé's character and virtue are also evident in his own writings as can be seen in the following examples. Regarding the virtue of faith, I referred to Augustine's definition of faith as entailing "a rational acceptance of God's existence, seriousness about his Word, and trust, submission, dedication, commitment and obedience to Him." These virtues were tellingly illustrated in two of Oom Bey's sermons published in this book, Obedience to God and Flame of Fire and Sledgehammer. In the latter, for instance, on the eve of his appointment as director of the CI, Oom Bey said the following to his congregation:

"What you yourselves may think of the step I am taking is not of decisive importance. What is of the utmost importance is that you should realise that God is summoning you through recent events. Let Christ take hold of you, Christ the living Word, let your thoughts and decisions be determined above all by him, the Word; let the future of your church, your people and your country be decided by him, the only living Word." (Naudé, n.d.: 19)

Regarding the virtues of faith, hope, courage and perseverance, Hannes Adonis (p. 121) referred to an article written by Oom Bey in the book Met de moed der hoop in which he characterizes a confessing church - which he had challenged the church in South Africa to become - as one "...where Christians in obedience to Christ endure oppression, persecution, mockery, and suffering and in their desperation and suffering turn to God in prayer, in faith and in hope so as to remain standing."

In his address to the Belydendekring Oom Bey challenged Christians in South Africa to be people of courage, moral heroes, in the daily walk of life. To pay attention and respond to the daily needs of others is an act of heroism:

"[I]f you were to ask me what the main characteristics are of the situation in our country today I would wish to describe it with this phrase: A situation of crisis. And the awareness and almost daily experience of that crisis is recognized or felt much more deeply in the South Africa where the majority of the people live and struggle, that the South Africa of the white minority living in splendid isolation and to a large degree unaware of what is actually happening in the country as a whole or, if partially aware, to a remarkable degree unconcerned of what these events imply..." [1984: 2]

In the same address, although he also refers to political justice - "[i]n no sphere of life is the violation of the basic concepts of political justice so seriously violated as in the area of the political rights of the black community" (ibid.) - he is also very 
much aware of the need for economic justice and that "the whole issue of riches and poverty, of wages and employment, of relationship between management and labourer, of worker rights and responsibilities are all part of the Christian witness which we need to understand and to address ourselves to." (ibid.) This again has implications for our commitment to action on behalf of the poor and for own lifestyles, indeed it asks for the virtue of moderation and temperance as "[t]his will require a critical self-appraisal of our personal lifestyle, of our lack of involvement up till now as Christians and as churches in the struggle of the trade union movement for basic rights for its members. It will require a confession of the Church's lack of interest and involvement in the struggle of millions of people for basic rights, income, conditions of employment, and expressions of the dignity of human labour. Our confession should include an admission of the church's traditional attitude to the whole labour and trade union movement of being largely uninterested and uninvolved" (ibid.). At the basis of our concern with justice is exactly what I referred to as the sensitivity towards so-called ordinary events and challenges of every day, or as Oom Bey asked in the context of this address: "Have we ever begun to ask ourselves what the full implications are of the prayer which we so constantly participate in: Give us this day our daily bread?" (ibid.).

Finally, we read in this book that Oom Bey also had something to say that I find applicable to what I have written in paragraph 4 of this article on the formation of virtues that "He [God] also fulfils this act of moral transformation in us in the midst of a congregation that is part of the broader denominational and ecumenical church, and that gathers in transforming worship services. The congregation provide room for practices, communal, consistent, collective, coordinated activities which help to actualise in us the good inherent to those practices, e.g. hospitality, friendships, witness and care." Oom Bey throughout his life acknowledged that we need our congregations to be and to act virtuously and with character in this world. In the article entitled The People he states this truth as follows:

"...when...the conscience of the people becomes blunted to obvious injustice perpetrated against millions of inhabitants of the country (apart from all the good that is being done), every Christian must do his [sic] duty as citizen with double vigilance, make his voice herald (also his protest, therefore, when necessary) and fulfil his political task. To do this effectively, he has the right and the duty - to ask his church that it should assist him in this highly responsible task. And only such a church or churches as are prepared to place the Biblical requirements of righteousness, neighbourly love and truth above all political servility, are able to perform this service towards their members. Thus - and only thus - does the Church do justice to its calling as regards the people." [1969: 2]

Finally, if love is the mother or at the heart of all other virtues, as Augustine and Thomas Aquinas teach us, the abundance of virtues embodied by Oom Bey, 
testifies to the abundance of love which he had in him. His mores were indeed determined and directed by his amores.

\section{Conclusion}

A young black Reformed theologian, who is a researcher at the Beyers Naudé Centre, Rodney Tshaka, bid Oom Bey farewell in this remarkable way at a memorial service on the Stellenbosch campus in September 2004: Ka nnele, O lwane ntwa e molemo, o mathile wa ba wa qeta sebaka. Robala ka Khotso moAfrikan (Surely, you have fought a good fight, you have completed the race. Sleep in peace African).

We at the Beyers Naudé Centre endeavour to honour this son of Africa. Not only do his character and virtuousness determine the ethos and values of the centre. The priorities that he discerned for himself for the last few years of his life, as spelled out in his autobiography, help to define the priorities and programmes of the centre that bears his name. Oom Bey spelled out the following four themes that he addressed in the last decade of his life: church unity and ecumenicity; economic justice; opposition to corruption and moral decay; reconciliation. ${ }^{16}$

I paid Oom Bey a visit on his last birthday on earth on the $10^{\text {th }}$ of May 2004. His last words to me were that churches and theology at Stellenbosch and in South Africa have a unique and indispensable contribution to make in the renewal of South Africa, the rest of Africa, and the world, and that we are called to do it in service of the coming of the kingdom. And with this emphasis on the coming of the kingdom, he perhaps revealed the quest for the kingdom as the heart of his character of justice, temperance, prudence, courage, and faith, hope and love. Those who seek the kingdom of God with undivided loyalty and commitment - there where God has planted them to flourish - are the moral heroes, the people of character and virtue. Only such endeavours honour the character and virtue that Beyers Naudé embodied through the grace of the triune God. We honour him if we respond appropriately to the challenge he put to Christians in South Africa in the conclusion of his farewell sermon in the Dutch Reformed congregation of Aasvoëlkop on 22 September 1963:

"Finally: this text has meaning for the other churches in South Africa and for the Christians in those Churches (white as well as non-white). You who with us confess faith in Christ and his Word: Is your fist obedience and your highest loyalty to Christ? Are you prepared to call on your people to seek this obedience and set it above all else? Even where it conflicts with their deepest human sentiments? Are you prepared to recognise injustice where injustice has occurred (also

16 The various research programmes of the Centre are: human dignity in the context of globalisation; the enforcement of social and economic rights and the building of a human rights culture; faith and identity; justice and peacebuilding; moral renewal; Christianity and civil society. 
against the Afrikaner) to give love and sympathy where it is needed and to humble yourself so that Christ may be magnified?

To all Christians of all churches and peoples and languages and races who sincerely seek and pray for this highest obedience to God comes his glorious assurance even for the unsure future: if God is for us, who can be against us? Amen" (Beyers Naudé n.d.: 11).

Beyers Naudé is no longer with us, but in a sense he lives on. This fact was illustrated to me in a striking way by Hannes Adonis's reaction to the photograph of his friend on the cover of this book: "This is how he is!" In a different way the contributors to this publication all testify to the fact that Beyers Naudé lives on in his legacy of character and virtue that still guides and inspires those who knew him. And the same will happen as we remember him, as we keep on making him a member again, with future generations.

\section{Bibliography}

Baron, W, Pettit, P and Slote, M 1999. Three methods of ethics. Oxford: Blackwell.

Bauman, Z 1993. Postmodern ethics. Oxford: Blackwell.

Beauchamp, TL and Childress, JF 2001. Principles of biomedical ethics. $5^{\text {th }}$ edition. New York: Oxford University Press.

Berkhof, H (ed) 1985. Met de moed der hoop. Opstellen aangeboden aan Dr C.F. Beyers Naudé. Baarn: Ten Have.

Berkhof, H 1979. Christelijk Geloof. Nijkerk: Callenbach.

Birch, B and Rasmussen, L 1989. Bible and ethics in the Christian life. Minneapolis: Augsburg Press.

Bonhoeffer, D (1995). Ethics. London: SCM Press.

Bosch, D 1997. Transforming Mission. Paradigm shifts in theology of mission. Maryknoll, New York: Orbis Books.

Botman, HR 2001. "Hope as the coming reign of God", in Brueggemann (ed.) Hope for the world. Mission in a global context. Louisville/London: Westminster John Knox Press, p. 69-81.

Capps, D 1987. Deadly sins and saving virtues. Philadelphia: Fortress Press.

Hauerwas, S and Pinches, C 1997. Christians among the virtues. Theological conversations with ancient and modern ethics. Notre Dame: University of Notre Dame Press.

Hauerwas, S 1975. Character and the Christian life: A study in theological ethics. San Antonio: Trinity University Press.

Hauerwas, S 1974. Vision and virtue: Essays in Christian ethical reflection. Notre Dame: Fides Press. 
Keenan, SJ 2002. "Moral theological reflections, in Harrington", D and Keenan, J (eds.) Jesus and the virtues. Building bridges between New Testament Studies and Moral Theology. Chicago: Sheed and Ward, p. 82-90.

Koopman, N 2005 Justice and land reform. Accepted for publication in forthcoming Studies in Reformed Theology, Amsterdam.

Koopman, N and Vosloo, R 2002. Die ligtheid van die lig. Morele oriëntasie in 'n postmoderne tyd. Wellington: Lux Verbi.BM.

Lebacqz, K 1994. "Theories of justice, in Boulton", W et al. (eds.) From Christ to the world. Introductory readings in Christian ethics. Grand Rapids: Eerdmans.

Lebacqz, K 1987. Justice in an unjust world: foundations for a Christian approach to justice. Minneapolis: Fortress Press.

Lebacqz, K 1986. Six theories of justice. Perspectives from philosophical and theological ethics. Minneapolis: Fortress Press.

Meyer, EE 2000. "Interpreting Luke with the Confession of Belhar", in Scriptura 72: 113-120.

Moltmann, J 1996. The coming of God. Christian eschatology. London: SCM Press.

Naudé, CFB [n.d.]. "Flame of Fire and Sledgehammer” in My Decision. CISA, p. 19.

Naudé, CFB [n.d.]. “Obedience to God” in My Decision. CISA, p. 3-11.

Naudé, CFB 1969. “The People” Pro Veritate, 15 February 1969.

Naudé, CFB 1984. “Confessing the Faith in South Africa Today" Belydendekring Bulletin. 15 December 1984, Vol. 2 No. 12.

Naudé, CFB 1998. Verzet en verzoening. Autobiografie. Baarn: Ten Have.

Randall, P (ed.) 1982. Not without honour. Tribute to Beyers Naudé. Johannesburg: Ravan Press.

Rothuizen, G 1973. Wat is ethiek? Kampen: Kok.

Van der Ven, J 1998. Formation of the moral self. Grand Rapids: Eerdmans.

Van Tongeren, P 2003. Deugdelijk leven. Een inleiding in de deugdethiek.

Amsterdam: Uitgeverij Sun.

Villa-Vicencio, C and De Gruchy, J (eds) 1985. Resistance and hope. South African essays in honour of Beyers Naudé. Cape Town/Johannesburg/Grand Rapids: David Philip/ Eerdmans.

Villa-Vicencio, C and Niehaus, C (1995) Many cultures, One nation. A Festschrift for Beyers Naudé. Cape Town: Human \& Rousseau.

Wogaman, JP 1989. Christian moral judgment. Louisville:Westminster/John Knox Press. 


\section{Other documents}

Confessing the one faith. An ecumenical explication of the apostolic faith as it is confessed in the Nicene-Constantinopolitan Creed (381). Geneva: World Council of Churches Publications.

Botman, H 2004. Tribute to Beyers Naudé. (unpublished tribute at memorial service for Beyers Naudé on 18 September 2004). 